\section{Pacific Northwest}

\section{National Laboratory}

Operated by Battelle for the

U.S. Department of Energy

\title{
Estimates of U.S. Commercial Building Electricity Intensity Trends: Issues Related to End-Use and Supply Surveys
}

\author{
D. B. Belzer
}

September 2007

Prepared for the U.S. Department of Energy under Contract DE-AC05-76RL01830 


\title{
DISCLAIMER
}

This report was prepared as an account of work sponsored by an agency of the United States Government. Neither the United States Government nor any agency thereof, nor Battelle Memorial Institute, nor any of their employees, makes any warranty, express or implied, or assumes any legal liability or responsibility for the accuracy, completeness, or usefulness of any information, apparatus, product, or process disclosed, or represents that its use would not infringe privately owned rights. Reference herein to any specific commercial product, process, or service by trade name, trademark, manufacturer, or otherwise does not necessarily constitute or imply its endorsement, recommendation, or favoring by the United States Government or any agency thereof, or Battelle Memorial Institute. The views and opinions of authors expressed herein do not necessarily state or reflect those of the United States Government or any agency thereof.

\author{
PACIFIC NORTHWEST NATIONAL LABORATORY \\ operated by \\ BATTELLE \\ for the \\ UNITED STATES DEPARTMENT OF ENERGY \\ under Contract DE-AC05-76RL01830
}

Printed in the United States of America

Available to DOE and DOE contractors from the

Office of Scientific and Technical Information,

P.O. Box 62, Oak Ridge, TN 37831-0062;

ph: (865) 576-8401

fax: (865) 576-5728

email: reports@adonis.osti.gov

\author{
Available to the public from the National Technical Information Service, \\ U.S. Department of Commerce, 5285 Port Royal Rd., Springfield, VA 22161 \\ ph: (800) 553-6847 \\ fax: (703) 605-6900 \\ email: orders@ntis.fedworld.gov \\ online ordering: http://www.ntis.gov/ordering.htm
}

This document was printed on recycled paper.

(9/2003) 


\section{Estimates of U.S. Commercial}

\section{Building Electricity Intensity Trends:}

Issues Related to End-Use and Supply Surveys

D. B. Belzer

September 2007

Prepared for

the U.S. Department of Energy

under Contract DE-AC05-76RL01830

Pacific Northwest National Laboratory

Richland, Washington 99352 


\section{Summary}

As part of any effort to assess the historical impacts of activities funded by DOE's Office of Energy Efficiency and Renewable Energy (EERE) to increase energy efficiency in the nation's stock of commercial buildings, it is critical to develop accurate historical measures of energy intensity (e.g., energy use per square foot of floor space). Currently, the Energy Information Administration (EIA) publishes data related to commercial building energy consumption based on two sources. The first is the periodic Commercial Building Energy Consumption surveys (CBECS). The second source relies on the reporting to EIA by energy suppliers of their sales to commercial customers. Over past two decades these sources suggest dramatically different trend rates of growth of electricity intensity-with the supplysurvey based estimates growing almost twice as fast as those based on the CBECS. Figure S.1 compares the overall intensities between these two sources. Since the mid 1980s, the trend growth rate in the aggregate electricity intensity from the supply survey data is about 90 percent greater than that implied by the CBECS.

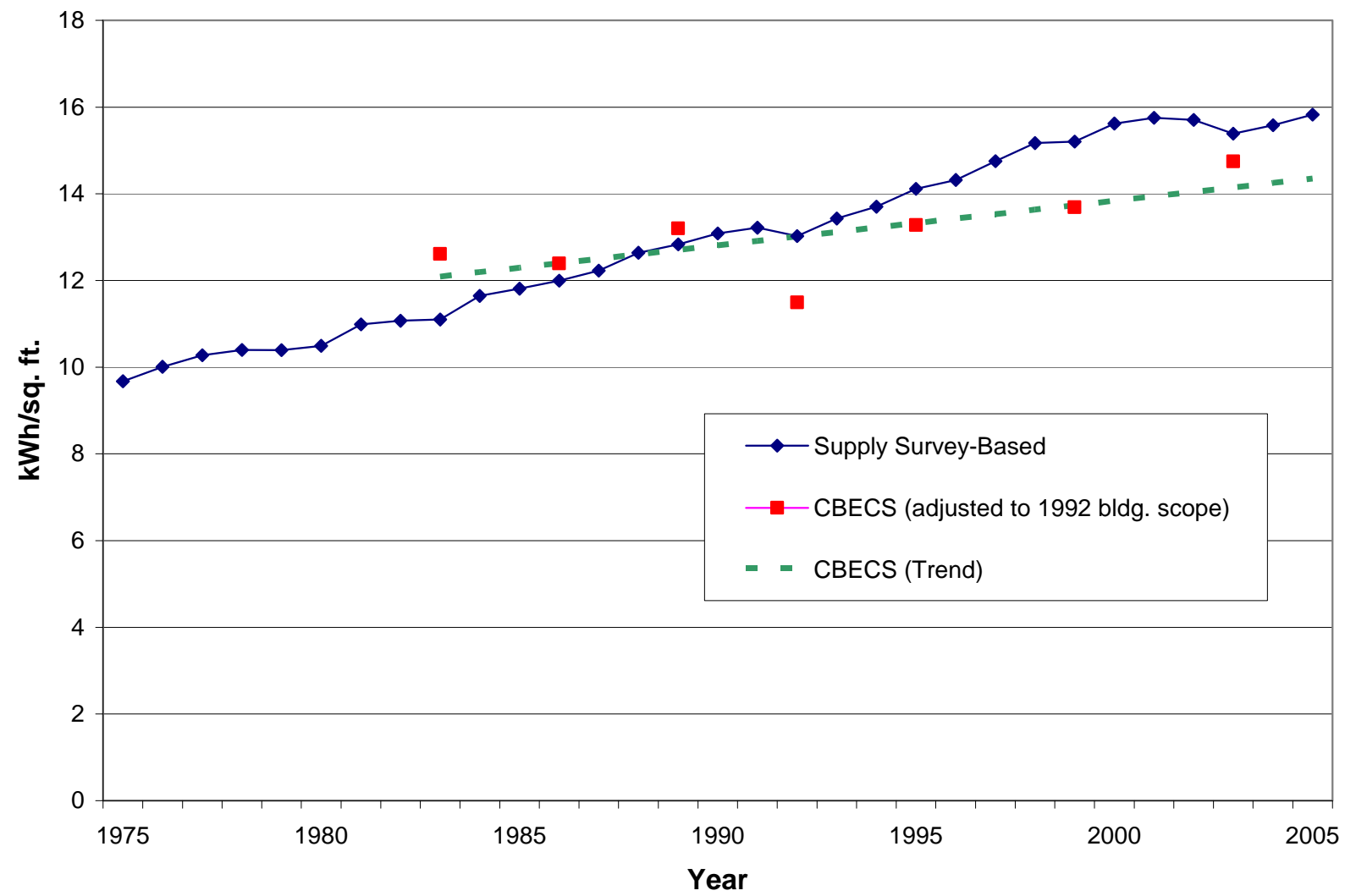

Figure S.1. Comparison of Electricity Intensities Based on Supply Survey and CBECS

Because EERE has had a variety of strategies aimed at reducing commercial building energy use over the past two decades, the existence of a credible series of historical energy (electricity) intensities is valuable for showing the relative impact of these efforts. EERE is also looked to by the Congress and various private organizations as a reliable source of information that can be used to aid in setting public policy with respect to improving building energy efficiency. For internal strategic planning, a better 
understanding of the behavior of commercial energy use and intensity over the recent past is also important.

This report attempts to assess the potential biases in both the supply-based and CBECS data sources with the aim of evaluating which source provides a more accurate picture of electricity use trends in the commercial building sector. In terms of the information based on the supply surveys, we seek to develop consistent historical estimates of the amount of electricity not used in commercial buildings, but nevertheless currently classified in the supply survey as commercial. In comparing the two data sources, the analysis focuses on two elements: 1) reclassification of electricity sales between industrial and commercial sales that appear to have occurred in a number of states and 2) estimation of electricity used for non-enclosed equipment that is used outside of commercial buildings, including outdoor lighting, water supply and treatment, cell phone sites, and irrigation. These factors together account for about eight percent of the observed growth in total commercial sector sales between 1992 and 2002. Table S.1 shows electricity consumption for the commercial sector, as published in the EIA's Annual Energy Review (AER), along with the various adjustments that serve to show the magnitude of consumption that may be more closely associated with commercial buildings.

Table S.1. Total Impact of Reclassification and Non-enclosed Equipment on Commercial Electricity Sales (terawatt-hours [TWh])

\begin{tabular}{|c|c|c|c|c|c|c|c|c|c|}
\hline Year & $\begin{array}{l}\text { Published } \\
\text { Supply- } \\
\text { Based } \\
\text { (AER) }\end{array}$ & $\begin{array}{l}\text { Reclassifi- } \\
\text { cation - } \\
\text { (subtract) }\end{array}$ & $\begin{array}{l}\text { Outdoor } \\
\text { Lighting }\end{array}$ & $\begin{array}{c}\text { Water } \\
\text { Supply and } \\
\text { Treatment }\end{array}$ & $\begin{array}{c}\text { Cell } \\
\text { Towers }\end{array}$ & Irrigation & $\begin{array}{l}\text { PNNL } \\
\text { Adjusted } \\
\text { Total }\end{array}$ & $\begin{array}{l}\text { Difference } \\
\text { (PNNL } \\
\text { Adjusted - } \\
\text { Published } \\
\text { Total) }\end{array}$ & $\begin{array}{c}\text { Ratio } \\
\text { (PNNL } \\
\text { Adjusted/ } \\
\text { Published } \\
\text { Total }\end{array}$ \\
\hline 1983 & 620.3 & -16.5 & 19.0 & 50.2 & 0 & 18.9 & 548.6 & -71.7 & 0.884 \\
\hline 1984 & 663.7 & -23.2 & 19.4 & 50.7 & 0 & 18.9 & 597.8 & -65.8 & 0.901 \\
\hline 1985 & 689.1 & -23.5 & 19.8 & 51.2 & 0 & 18.9 & 622.7 & -66.4 & 0.904 \\
\hline 1986 & 714.7 & -23.7 & 20.2 & 51.8 & 0 & 18.9 & 647.6 & -67.1 & 0.906 \\
\hline 1987 & 744.1 & -24.7 & 20.6 & 52.3 & 0 & 18.9 & 677.0 & -67.1 & 0.910 \\
\hline 1988 & 784.0 & -25.8 & 20.9 & 52.8 & 0 & 18.9 & 717.1 & -66.9 & 0.915 \\
\hline 1989 & 810.9 & -26.2 & 21.3 & 53.4 & 0 & 18.9 & 743.4 & -67.4 & 0.917 \\
\hline 1990 & 838.3 & -26.6 & 21.7 & 54.1 & 0.04 & 18.9 & 770.1 & -68.1 & 0.919 \\
\hline 1991 & 855.2 & -26.9 & 21.9 & 54.9 & 0.09 & 18.9 & 786.4 & -68.9 & 0.919 \\
\hline 1992 & 850.0 & -32.5 & 22.2 & 55.7 & 0.13 & 18.9 & 785.7 & -64.3 & 0.924 \\
\hline 1993 & 884.7 & -28.4 & 22.4 & 56.4 & 0.26 & 18.9 & 815.1 & -69.6 & 0.921 \\
\hline 1994 & 913.1 & -27.5 & 22.7 & 57.2 & 0.39 & 18.9 & 841.5 & -71.6 & 0.922 \\
\hline 1995 & 953.1 & -16.7 & 23.3 & 58.0 & 0.69 & 18.9 & 869.0 & -84.1 & 0.912 \\
\hline 1996 & 980.1 & -18.5 & 23.9 & 58.7 & 0.99 & 18.9 & 896.1 & -84.0 & 0.914 \\
\hline 1997 & $1,026.6$ & 2.6 & 23.3 & 59.5 & 1.29 & 18.9 & 921.1 & -105.5 & 0.897 \\
\hline 1998 & $1,078.0$ & 2.4 & 23.4 & 60.3 & 1.59 & 18.9 & 971.4 & -106.6 & 0.901 \\
\hline 1999 & $1,103.8$ & 2.4 & 24.6 & 61.1 & 1.89 & 18.9 & 994.9 & -108.9 & 0.901 \\
\hline 2000 & $1,159.3$ & 10.1 & 26.2 & 61.9 & 2.19 & 18.9 & $1,040.1$ & -119.3 & 0.897 \\
\hline 2001 & $1,191.2$ & 13.1 & 27.3 & 62.6 & 2.60 & 18.9 & $1,066.7$ & -124.5 & 0.895 \\
\hline 2002 & $1,205.1$ & 7.5 & 28.2 & 63.3 & 3.01 & 18.9 & $1,084.2$ & -120.9 & 0.900 \\
\hline 2003 & $1,197.2$ & 3.0 & 30.0 & 64.1 & 3.42 & 8.9 & $1,087.8$ & -109.4 & 0.909 \\
\hline 2004 & $1,229.0$ & 3.0 & 31.6 & 64.8 & 3.83 & 4.9 & $1,120.9$ & -108.1 & 0.912 \\
\hline 2005 & $1,266.7$ & 3.0 & 33.4 & 65.6 & 4.16 & 2.9 & $1,157.7$ & -109.0 & 0.914 \\
\hline
\end{tabular}

Figure S.2 plots the published and adjusted commercial sales along with the electricity consumption reported by the CBECS. Clearly, the most obvious result is that the CBECS and adjusted utility-based estimates show reasonable agreement over the last four CBECS cycles.

Given the congruence of the CBECS to the adjusted total electricity consumption for 1992 and later years, the CBECS estimates of electricity consumption for 1983, 1986, and 1989 are very high. We recognize 
that the uncertainty of the various adjustments is somewhat greater during the 1980s as compared to more recent years, but even if the adjustments (for lighting, water supply, and irrigation) were only half of what is shown in Table S.1, the CBECS values would be relatively high compared to the adjusted utility-based estimates. If the adjusted supply-based estimates can be considered to reasonably match the CBECS scope and definition, the 1983 CBECS estimate is much too high. The adjusted supply estimate is even below the lower 95 percent confidence limit for that year. As the 1979 (not shown) and 1983 surveys were based on a different sampling procedure than the later CBECS, one can attribute the difference to the way the sample was selected and converted into a national estimate.

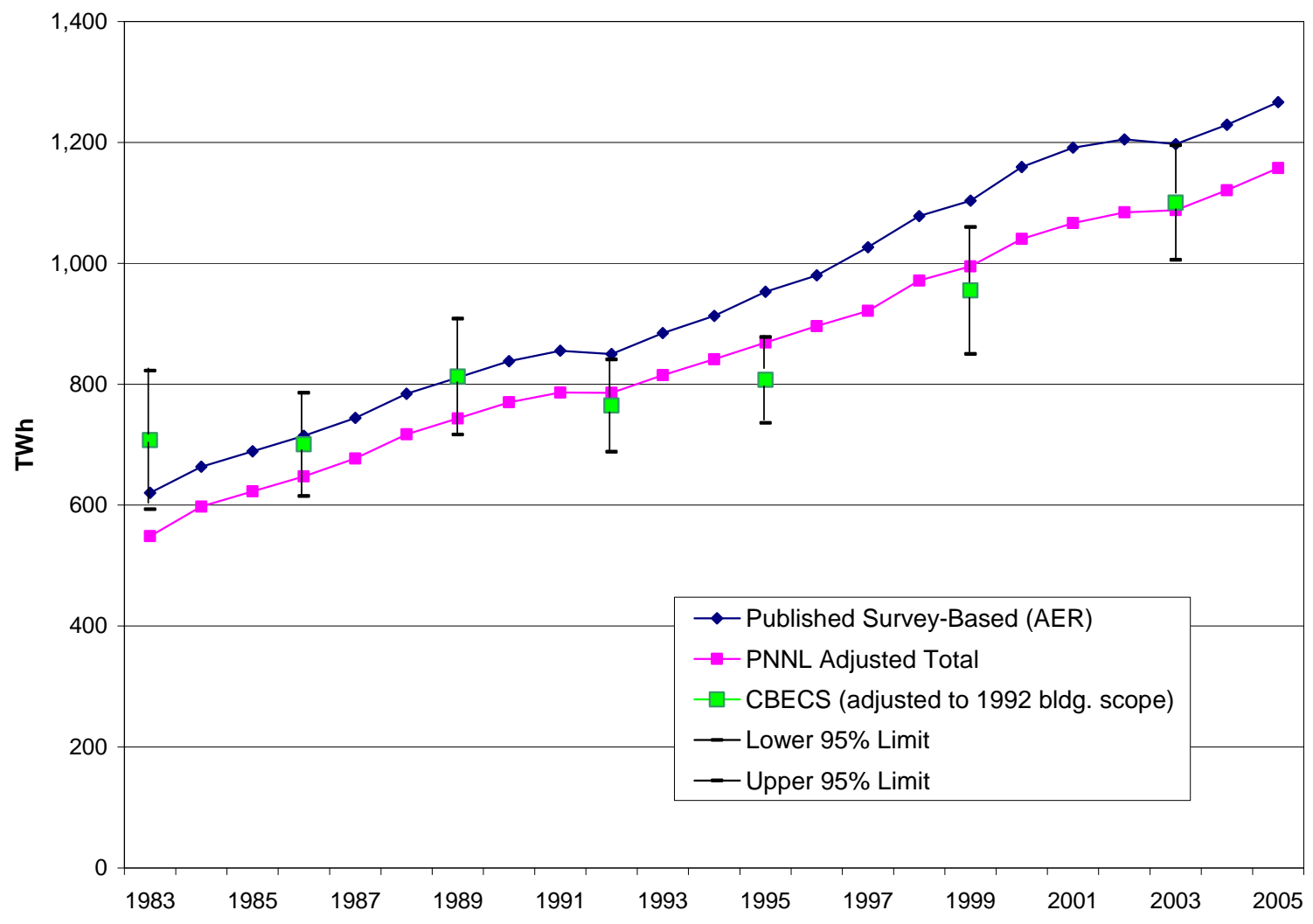

Figure S.2. Total Commercial Sector Electricity Use, Published-AER vs. Adjusted (TWh)

Electricity intensities based on the adjusted commercial sales consumption estimates match up closely with the CBECS intensities for 1992 and later. This comparison is shown in Figure S.3. 


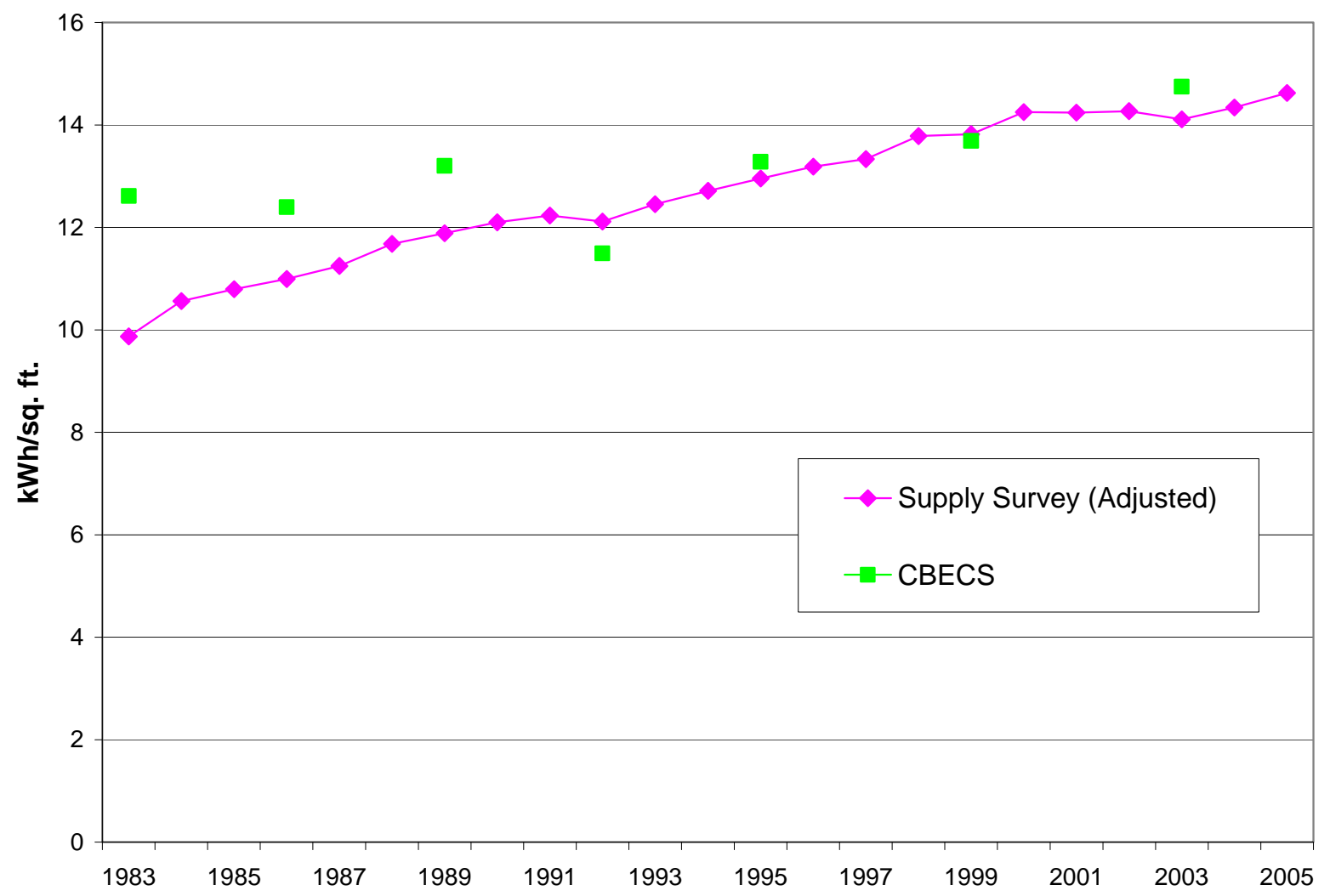

Figure S.3. Comparison of CBECS and Adjusted Supply Survey Electricity Intensities.

The total of all the adjustments shown in the second to last column of Table S.1 is, however, insufficient to explain difference between the longer-term intensity trends derived from the two data sources. Over the two-decade period 1985 to 2005, the intensity based on the adjusted supply survey data actually increases slightly faster (1.53 percent/yr) than an intensity (shown in Figure S.1) based on the published supply data (1.47 percent/yr). However, as shown in Figure S.3, the correspondence between the absolute intensities based on the adjusted supply survey estimates and the CBECS since 1992 is strikingly close.

From another perspective, however, if the 1992 CBECS is omitted, a gradual and relatively consistent trend of increasing intensities is provided by the full set of CBECS. This perspective still indicates that the CBECS trend growth in electricity consumption and aggregate intensity is lower than that suggested by the supply survey data. However, it is plausible that the CBECS estimates do provide the more accurate picture of long-term intensity trends. The supply survey data is subject to variety of factors that may be biasing the reported consumption for both the commercial and industrial sectors.

At this point, there appears to be no completely satisfactory explanation of the discrepancy between the adjusted supply survey consumption estimates and the CBECS when analyzed over a period beginning in the early 1980s and continuing to the present. The correspondence between the sources is closer after 1992 and for many purposes this shorter historical perspective is sufficient. Finally, it is recommended that any broad statements about trends in overall commercial electricity use and intensity always be accompanied with a reference to the underlying data source. 


\section{Contents}

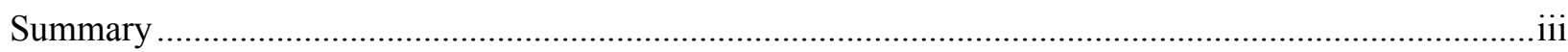

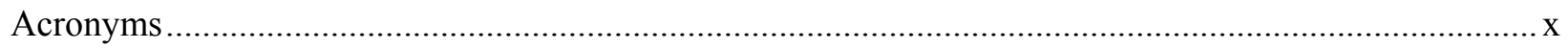

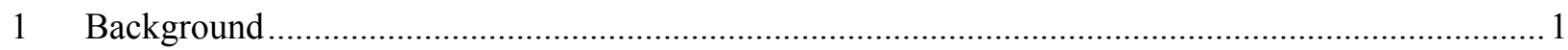

2 Classification Issues Related to Electricity Utility Customer Accounts............................................ 7

2.1 Utility Reported Sales collected by Supply Survey (Form EIA-861) ..................................... 7

2.2 Classification Changes of Electric Utility Accounts: Industrial and Commercial .................... 13

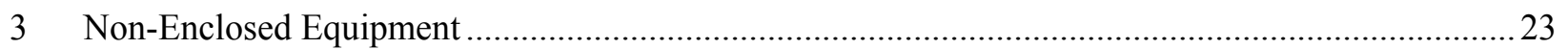

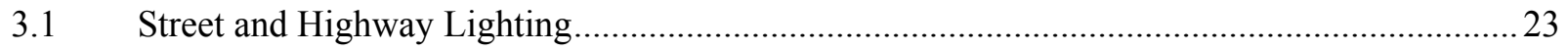

3.1.1 Street and Highway Lighting from EIA-861 ............................................................ 23

3.1.2 Street and Highway Lighting Electricity Use: 2002 Navigant Lighting Study ................... 26

3.1.3 Blended Results from EIA-861 and Navigant Study .......................................................2 27

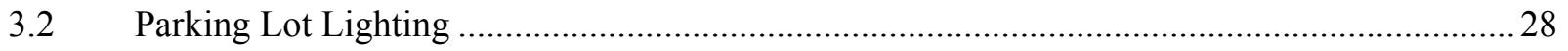

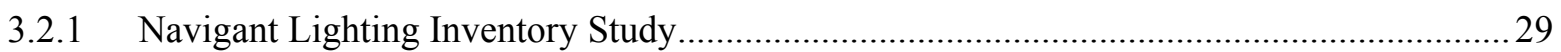

3.2.2 CEC Assessment of Outdoor Lighting in California.......................................................... 32

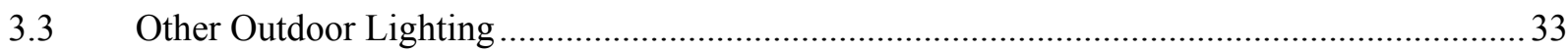

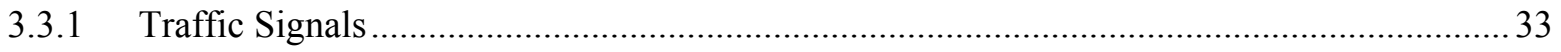

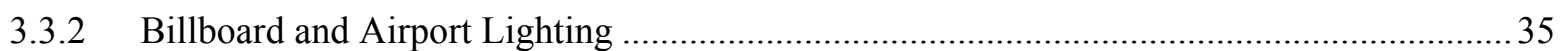

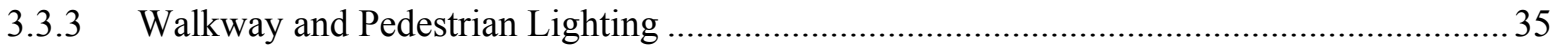

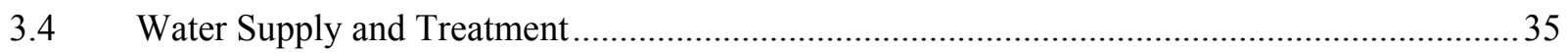

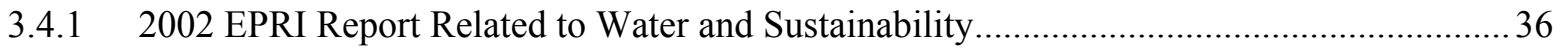

3.4.2 TIAX Report on Miscellaneous Commercial Electricity Uses ............................................ 38

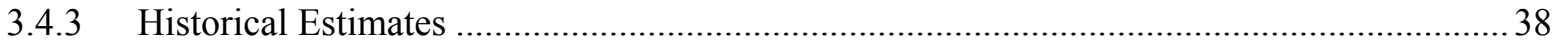

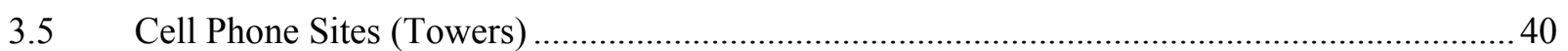

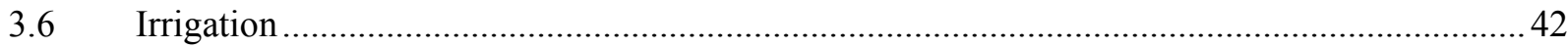

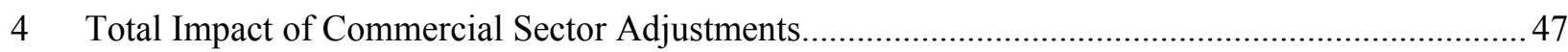

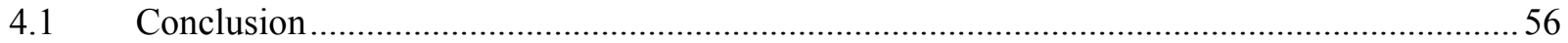

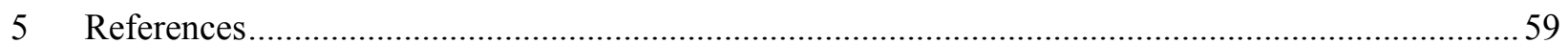

\section{Figures}

Figure S.1. Comparison of Electricity Intensities Based on Supply Survey and CBECS.........................iii

Figure S.2. Total Commercial Sector Electricity Use, Published-AER vs. Adjusted (TWh) ..................... V

Figure S.3. Comparison of CBECS and Adjusted Supply Survey Electricity Intensities.........................vi

Figure 1.1. Comparison of Annual Floor Space Stock with CBECS ................................................... 3

Figure 1.2. Comparison of Electricity Intensities Based Upon Supply Survey and CBECS ..................... 4

Figure 2.1. Supply-based and CBECS Estimates of Total Commercial Electricity Consumption ............ 11

Figure 2.2. Reported Commercial and Industrial Electricity for New Hampshire, 1990-2004 ................ 14 
Figure 2.4. Commercial and Industrial Electricity Sales: Maryland, Michigan, Minnesota, and Mississippi.

Figure 2.5. Commercial and Industrial Electricity Sales: South Dakota and New York.

Figure 2.6. Classification Changes between Industrial and Commercial Sectors for Tennessee, 1980-2004 19

Figure 2.8. Published and Adjusted Total Commercial Electricity Sales (Method A) ........................... 22

Figure 2.9. Published and Adjusted Total Commercial Electricity Sales (Method B)............................ 22

Figure 3.1. Electrical Consumption per Residential Customer and Number of Customers, 1997 ............ 24

Figure 3.2. Published and Adjusted Electricity Series for Irrigation Reclassification ............................. 45

Figure 4.1. Total Commercial Sector Electricity Use, Published-AER vs. Adjusted Series (TWh)......... 49

Figure 4.2. Comparison of Adjusted Intensities from the CBECS and Supply Survey Data.................... 51

Figure 4.3. Electricity Intensities by Building Type: 1986, 1989, 1992 and 1995 CBECS......................53

\section{Tables}

Table S.1. Total Impact of Reclassification and Non-enclosed Equipment on Commercial Electricity Sales (terawatt-hours [TWh]) iv

Table 1.1. CBECS Floor Space Adjusted to 1992 CBECS Building Scope and Definition (Billion Square Feet) ........................................................................... 3

Table 1.2. Comparison of Annual Growth Rates of Electricity Intensities, 1985-2005 ............................5

Table 2.1. Customer Class Definitions for Form EIA-861 (Pre-2003) .................................................... 8

Table 2.2. Electricity Sales by Sector Published in the Electric Power Annual (TWh)........................... 9

Table 2.3. Alternative Estimates of Commercial Electricity Consumption (TWh) from the Electric Power Annual (EPA) and the Annual Energy Review (AER) (Terawatt-Hours)... 10

Table 3.1. Estimates of Total Street Lighting Electricity Use for 1997, Based on EIA-861 ...................25

Table 3.2. Annual Estimates Electricity Consumption for Street and Highway Lighting Based on EIA-861 .26

Table 3.3. Estimates of Street and Highway Electricity Based on Blended Estimates from the EIA-Survey and the 2002 Navigant Lighting Study .............................................2

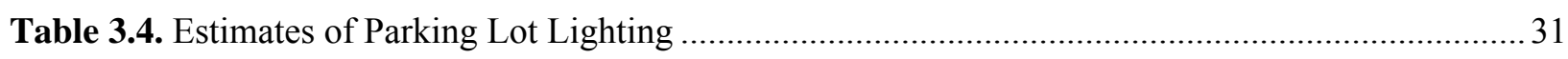

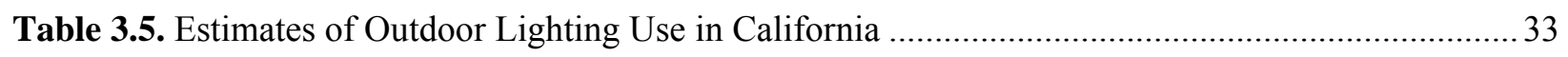

Table 3.6. Historical Estimates of Electricity Consumption for Traffic Signals..................................... 34

Table 3.7. Annual Estimates of Electricity Use for Water Supply and Treatment.................................. 40

Table 3.8. Average Power Consumption and Distribution by Type of Cell Site .................................... 41

Table 3.9. Estimated Electricity Consumption by Cell Phone Sites in the U.S. ...................................... 42

Table 3.10. Estimates of Irrigation Electricity Use (and Adjustments to Reported Data) ........................ 44 
Table 4.1. Total Impact of Reclassification and Non-enclosed Equipment

on Commercial Electricity Sales (Terawatt-hours).

Table 4.2. Utility Account Classification of Commercial Building Electricity: 1989, 1992, and 1995.... 56 


\section{Acronyms}

$\begin{array}{ll}\text { ADL } & \text { Arthur D Little } \\ \text { AER } & \text { Annual Energy Review } \\ \text { BT } & \text { Building Technologies } \\ \text { CBECS } & \text { Commercial Building Energy Consumption Surveys } \\ \text { CDWR } & \text { California Department of Water Resources } \\ \text { CEC } & \text { Canadian Electric Code } \\ \text { CTIA } & \text { Cellular Telecommunications and Internet Association } \\ \text { DOE } & \text { U.S. Department of Energy } \\ \text { EERE } & \text { Efficiency and Renewable Energy } \\ \text { EIA } & \text { Energy Information Administration } \\ \text { EPA } & \text { Electric Power Annual } \\ \text { EPRI } & \text { Electric Power Research Institute } \\ \text { FHWA } & \text { Federal Highway Administration } \\ \text { GWh } & \text { gigawatt hour } \\ \text { HID } & \text { High Intensity Discharge } \\ \text { IPI } & \text { International Parking Institute } \\ \text { LBNL } & \text { Lawrence Berkeley National Laboratory } \\ \text { LED } & \text { Light Emitting Diode } \\ \text { LPD } & \text { Lighting Power Density } \\ \text { MWh } & \text { megawatt hour } \\ \text { NBECS } & \text { Nonresidential Building Energy Consumption Survey } \\ \text { NEMA } & \text { National Electrical Manufacturer's Association } \\ \text { NPPC } & \text { Northwest Power Planning Council } \\ \text { PNNL } & \text { Pacific Northwest National Laboratory } \\ \text { RUS } & \text { Rural Utility Service } \\ \text { SEDR } & \text { State Energy Data Report } \\ \text { SEDS } & \text { State Energy Data System } \\ \text { TWh } & \text { terawatt hour } \\ \text { USGS } & \text { U.S. Geological Survey } \\ \end{array}$




\section{Background}

The basic objective of the Department of Energy's building efficiency programs is to slow, and ultimately reverse, the growth of energy use by the buildings sector. Clearly, to measure progress in that effort, a reasonably accurate picture is needed of how much energy is being used in buildings at any point in time. An important role of the Energy Information Administration (EIA) is to develop accurate estimates of the energy used in the building sector and in the other major end-use sectors of the U.S. economy.

The statistics related to energy use in buildings are derived from two different sources. The first source involves the periodic building surveys initiated by EIA in the late 1970s. For commercial buildings, the Commercial Building Energy Consumption Survey (CBECS) has been conducted in 1979, 1983, 1986, $1989,1992,1995,1999$, and 2003. The CBECS is a stratified national sample of approximately 6000 commercial buildings and collects information on the physical and operating characteristics of each building as well as its annual energy consumption. The second source relates to the surveys of electric and natural gas utilities. These energy suppliers provide monthly information to EIA on energy sales, customers, and revenues. This information is collected on the basis of the types of rate structures for major classes of customers. Although EIA provides general guidelines related to classifying accounts, it depends on the utilities to classify their various accounts into the residential, commercial or industrial categories.

For commercial buildings, the broadest measure of energy efficiency is provided by estimates of annual energy use per square foot of floor space. Energy intensities based on this definition have been generated and published by all of the CBECS since its inception. Because the CBECS is only conducted every three to four years and because there is a significant degree of sampling variation associated with these estimates (blurring the changes from one survey to the next), an alternative metric based on the annual supplier information is desirable. However, to make use of this information, we also need robust measures of the stock of commercial floor space for each year.

Annual historical estimates of commercial floor space are not currently generated by any federal statistical agency (including EIA). Over the past decade, Pacific Northwest National Laboratory (PNNL) has attempted to develop historical estimates of commercial floor space. These estimates are based on a combination of data from the CBECS and floor space additions provided by the F.W. Dodge Division of the McGraw-Hill publishing company. The "Dodge" construction data are published in the Statistical Abstract of U.S. ${ }^{1}$ Given the lack of detailed Dodge data by building type from this source, the estimates thus far have been developed only for aggregate commercial floor space in the U.S. The estimation of floor space follows a perpetual inventory approach: stock in any given year is based on the previous year's stock, new additions, and estimated retirements from the stock. ${ }^{2}$ Based on previous PNNL work,

\footnotetext{
${ }^{1}$ The most recent data are taken from Table No. 939, "Construction Contacts-Value of Construction and Floor Space of Buildings by Class of Construction: 1980:2004." Classes of construction are very broad: commercial (includes office, retail, lodging, and warehouse), educational, health, public buildings, religious, social and recreational, and miscellaneous. The data are published only in the hard copy version of the Statistical Abstract, and are not available on the web.

${ }^{2}$ The estimates of retirements are based on two-parameter logistic survival curve, using the same functional form as that used by EIA in the commercial NEMS model. The parameters of this curve were estimate by finding the best statistical fit to four data points corresponding to the percentage of surviving stock for four vintages $(<1920,1920$ $1945,1946-1959,1960-1986)$ as implied by the 1999 CBECS in comparison to the 1989 CBECS. The median
} 
the current series of historical commercial floor space is benchmarked to the 1989 CBECS. ${ }^{3}$

Unfortunately, new floor space additions from F.W. Dodge are very likely to underestimate the actual amount of new floor space. ${ }^{4}$ An adjustment of this Dodge-based underestimate for the period 1960-1989 is based on the amount of floor space estimated by the 1989 CBECS to have been built during this period. This adjustment factors up the Dodge additions by 26 percent to account for this underreporting. For the time period starting in 1990, it is not yet clear what magnitude of adjustment is appropriate. Based solely on the 2003 CBECS, the amount of new commercial floor space built between 1990 and 2003 is roughly 15 percent greater than that reported by F.W. Dodge. Thus, based on the two CBECS (1989 and 2003), we believe that an appropriate adjustment for this recent 14-year period lies in the range of 15 percent to 25 percent. To simplify the analysis, we have chosen to use a single adjustment factor of 20 percent to generate the floor space additions during the 1990-2004 time frame.

Figure 1.1 compares the annual floor space developed from this perpetual inventory approach and the estimates of national floor space from the various CBECS. The CBECS numbers in the figure are based on the definitional scope of buildings included in the CBECS for 1986 through 1992. This definition includes parking garages and commercial buildings in manufacturing complexes (buildings that are presumed to be included in the Dodge construction data). Table 1.1 summarizes our post-1992 estimates of floor space in parking garages and commercial buildings on manufacturing facilities.

lifetime for all commercial buildings from this estimation was 59 years. For recent years, the survival curve generates an average retirement rate of about $0.7 \%$ per year.

${ }^{3}$ The floor space stock is periodically updated by PNNL. No recent formal documentation of these estimates has been prepared. The general approach to developing the historical time series of floor space was documented in a 1994 evaluation report prepared by Brookhaven National Laboratory for EERE/BT (Pierce 1994).

${ }^{4}$ This assertion is based primarily on the methodology used by the U.S. Census Bureau to estimate the value of new nonresidential construction. In the current methodology, the Census Bureau increases the value of construction from a sample of Dodge construction projects by 25 percent to "account for undercoverage of construction projects not covered by MHC" (McGraw-Hill Construction). The specific factor is based on periodic comparison of data from Dodge and from building permits. This methodology is discussed in an appendix to the reports related to the value of new construction put in place: http://www.census.gov/const/C30/methodology.pdf. In years prior to 2003, the adjustment factor used by the Census Bureau was $28 \%$. Unfortunately, the Census Bureau is concerned only with the value of new construction and so the adjustment factors cannot be assumed to apply equally to floor space. 


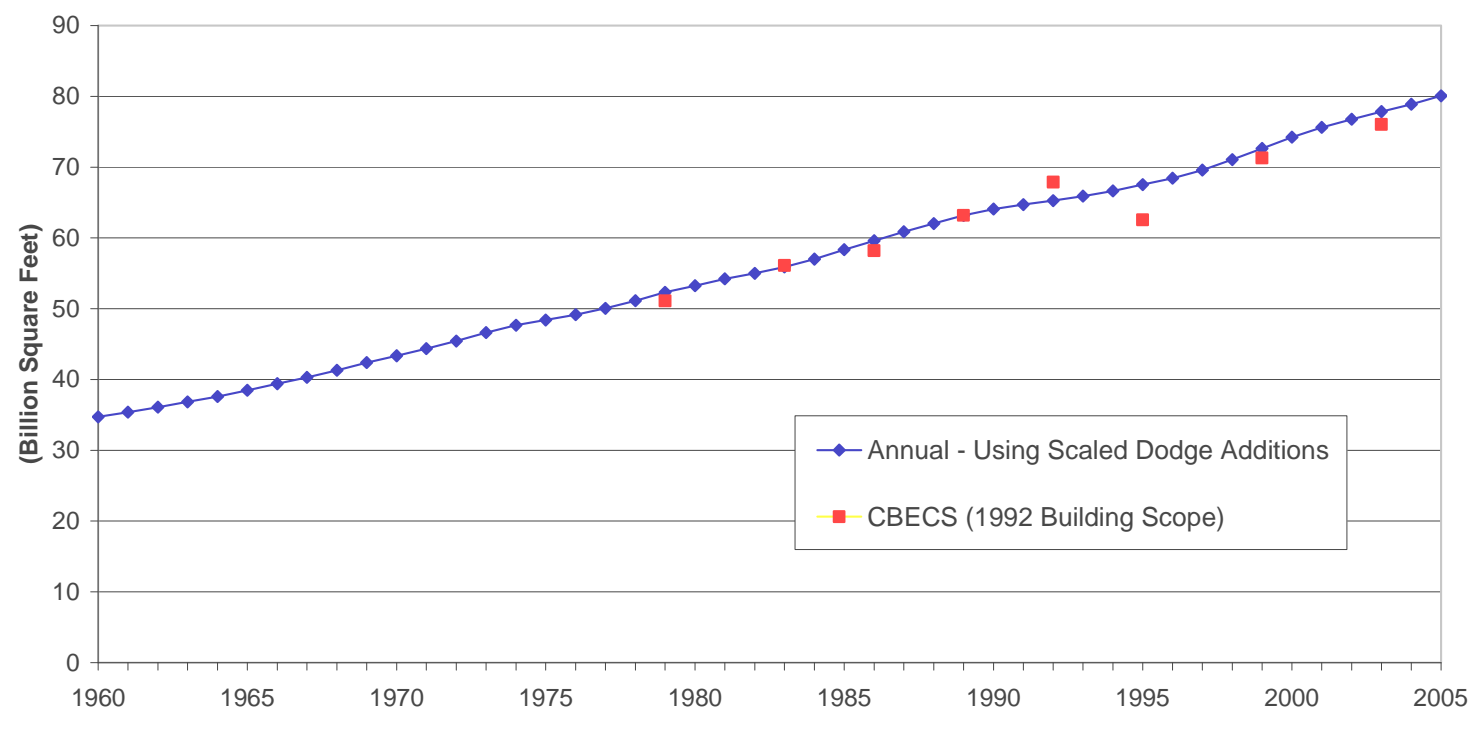

Figure 1.1. Comparison of Annual Floor Space Stock with CBECS.

Table 1.1. CBECS Floor Space Adjusted to 1992 CBECS Building Scope and Definition (Billion Square Feet)

\begin{tabular}{cccccc}
$\begin{array}{c}\text { CBECS } \\
\text { Survey } \\
\text { Year }\end{array}$ & $\begin{array}{c}\text { "Old" } \\
\text { Scope }\end{array}$ & $\begin{array}{c}\text { "New" } \\
\text { Scope }\end{array}$ & Difference & $\begin{array}{c}\text { Parking } \\
\text { Garages }\end{array}$ & $\begin{array}{c}\text { Multibuilding } \\
\text { Manufacturing }\end{array}$ \\
\hline 1979 & 51.088 & & & & \\
1983 & 56.116 & & & & \\
1986 & 58.199 & & & & \\
1989 & 63.184 & & & & \\
1992 & 67.876 & 64.269 & 3.607 & 1.652 & 1.955 \\
1995 & 62.544 & 58.772 & 3.772 & 1.807 & 1.965 \\
1999 & 71.496 & 67.338 & 4.158 & 2.194 & 1.965 \\
2003 & 76.286 & 71.658 & 4.628 & 2.663 & 1.965
\end{tabular}

Notes:

1) "Old" Scope includes parking garages and commercial buildings on multi building manufacturing facilities. For the 1992 CBECS, these building types contained about 3.6 billion square feet.

2) The post-1992 growth in parking garage floor space was estimated by converting new construction expenditure data from the Bureau of Census into constant 2006 dollars (assuming a 5 percent increase in the construction price deflator from 2005 to 2006). These estimates were converted to floor space by assuming a constant $\$ 13,000$ per new parking space and an average of 350 square feet per parking space in dedicated parking facilities. The figure of $\$ 13,000$ per space was based on information supplied by Walker Parking Consultants (to be published in the next edition of the ITE Transportation Planning Handbook.) The relatively large percentage increase in parking garage floor space is consistent with several other data sources: 1) An inference from unpublished Dodge data yields an estimated 160 million sq. ft. of new parking garages built in 2001. 2) The International Parking Institute indicates an additional 4.4 million parking spaces in structures have been built over the past fifteen years, representing approximately 1.5 billion square feet (personal communication, Kim Jackson, International Parking Institute, e-mail message transmitted on November 2, 2006). However, some of these parking spaces are in facilities other than parking garages (e.g., office buildings, high-rise apartment buildings, etc.) 
3) The floor space estimates for commercial buildings on multibuilding manufacturing complexes were left unchanged, as manufacturing employment grew very little during the 1990s and had declined in 2003.

Given these estimates of historical commercial floor space, it is straightforward to calculate a series of aggregate energy intensities. This report focuses on electricity intensity. Figure 1.2 compares the national average electricity intensities (in $\mathrm{kWh} / \mathrm{sq}$. $\mathrm{ft}$.) derived from the supply surveys versus the intensities from various CBECS. ${ }^{5}$ The commercial electricity sales data is taken from EIA's Annual Energy Review. The difference in the historical pattern between the supply and end-user surveys is striking. The periodic CBECS suggest a slight upward trend in electricity consumption per square foot from 1986. A linear trend line - based on a linear regression for the seven CBECS from 1986 to 2003 - is inserted in the figure to illustrate this assertion.

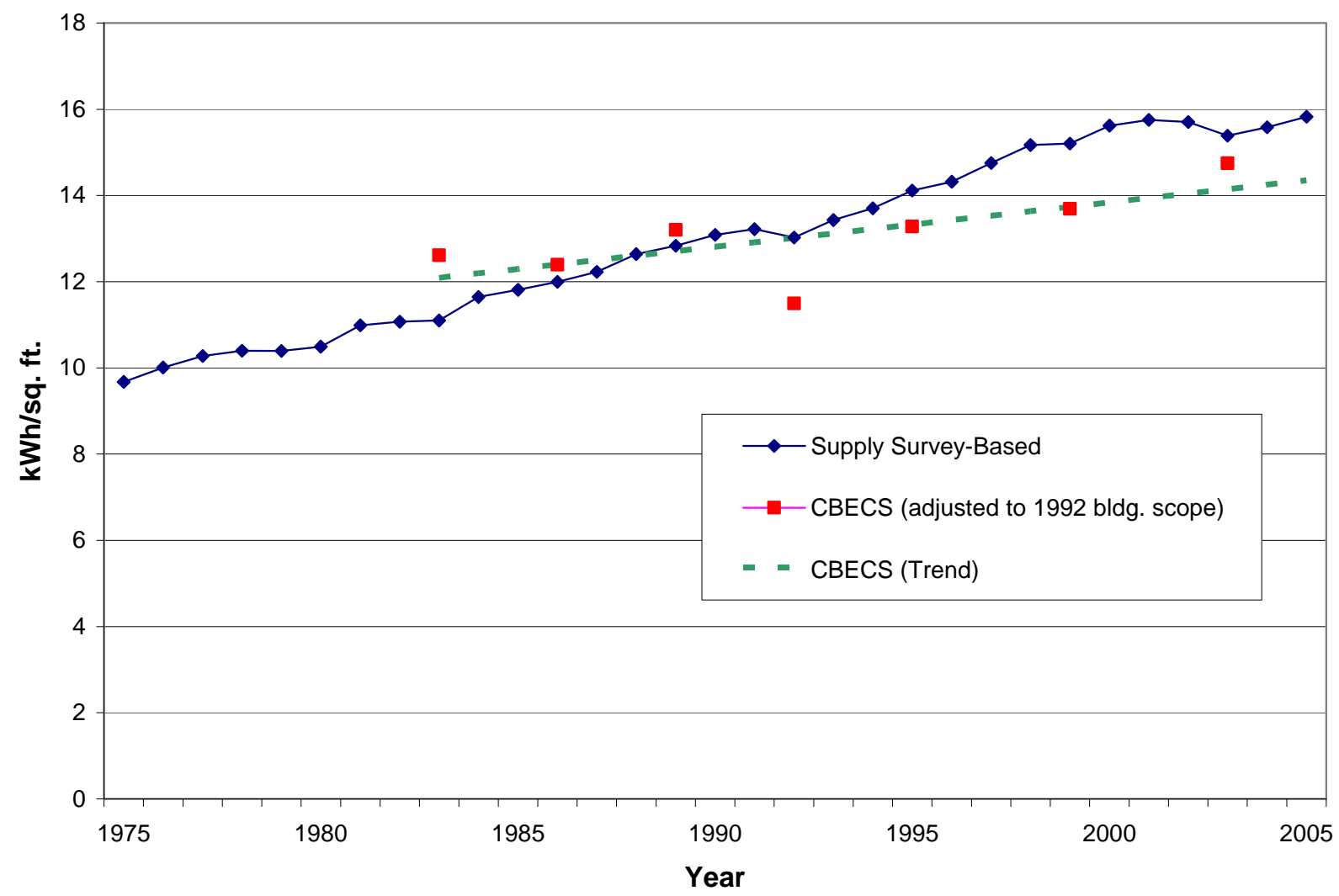

Figure 1.2. Comparison of Electricity Intensities Based Upon Supply Survey and CBECS

\footnotetext{
${ }^{5}$ As discussed above, the 1995 CBECS and later CBECS exclude parking garages and commercial buildings in multibuilding industrial/manufacturing complexes. When estimates of the square footage and electricity use for these building types are included for these later years, the average all-building intensities are about $0.1 \mathrm{kWh} / \mathrm{sq}$. $\mathrm{ft}$. lower than the published values. For 1983, the intensity of $12.61 \mathrm{kWh} / \mathrm{sq} . f t . d e r i v e d$ from information provided on EIA's CBECS website in a section entitled "Trends in the Commercial Buildings Sector." See website http://www.eia.doe.gov/emeu/consumptionbriefs/cbecs/cbecs trends/main menu.html. As derived from the published electricity consumption and floor space values, the aggregate electricity intensities for 1986, 1989, and 1992 are 12.40, 13.20 and $11.49 \mathrm{kWh} / \mathrm{sq}$. ft., respectively. The published (revised) values for 1995, 1999, and 2003 are 13.39 (13.28), 13.82 (13.69), and 14.86 (14.75), respectively.
} 
Figure 1.2 clearly shows that the intensities based on the reported commercial sales by suppliers display distinctly higher rate of increase over the comparable time period.

The supply-based intensities shown in Figure 1.2 are based on the published estimates of commercial electricity use in the Annual Energy Review. ${ }^{6}$ The original source of this information is from EIA's utility survey Form EIA-861 - an annual collection of data from the nation's more than 3,000 electric utilities. Up until 2004, EIA asked utilities to provide sales data for street lighting and "other" uses. This consumption is included in commercial sales, although some of it is not consumed in commercial buildings. In Section 2, the nature of information collected via Form EIA-861 is discussed in detail.

Table 1.2 attempts to quantify the differences in the trend rates of changes among these series. Looking over the twenty-year period 1985-2005, the supply-based electricity intensity has increased about 85 percent faster than the trend rate implied from the various CBECS. Because of year-to-year variation in weather and economic activity, the estimated growth rates are sensitive to the particular end points (years) chosen. For purposes of comparison, we examine the trends over the period 1985-2005.

For the CBECS, a linear trend line was fitted to the intensities from the seven CBECS, beginning with the 1983 CBECS. This linear trend line is shown as the dashed line in Figure 1.2. Based on the predicted values from this trend line for 1985 and 2005, the annual percentage growth rate was 0.8 percent as shown in the top line of Table 1.2.

Several methods can be considered to calculate a comparable growth rate for the supply survey estimates. The first is to select the same seven years corresponding to the CBECS, estimate a linear regression, and compute the annual growth rate between the predicted values for 1985 and 2005. This growth rate, 1.59 percent per year, is shown on the top line of Table 1.2. (To avoid complexity, this trend line is not shown in Figure 1.2.)

A second method also employs a linear regression, but is based on all 21 years from the 1985 and 2005 . The growth rate is almost identical (1.61 percent) to the value generated above from only the CBECS years.

A third method simply uses the actual intensities only for 1985 and 2005 to compute the annual growth rate. Because this method ignores the very high intensities in the late 1990s and extending through 2002, the annual growth rate is lower by about 0.1 percent per year as compared to regression-based estimates. Using this lowest estimate of the growth rate from the supply survey-based intensities, the growth rate is about 90 percent greater than that based on the CBECS.

Table 1.2. Comparison of Annual Growth Rates of Electricity Intensities, 1985-2005

\begin{tabular}{|c|c|l|}
\hline CBECS & Supply-Survey Based & Method for Supply-Survey Growth Rate \\
\hline $0.78 \%$ & $1.59 \%$ & $\begin{array}{l}\text { Linear regression, CBECS years (1983-2003), } \\
\text { growth rate based on predicted values for } \\
1985 \text { and 2005 }\end{array}$ \\
\hline NA & $1.61 \%$ & $\begin{array}{l}\text { Linear regression, all years, growth rate based } \\
\text { on predicted values for 1985 and 2005 }\end{array}$ \\
\hline NA & $1.47 \%$ & $\begin{array}{l}\text { Growth rate based on actual values for } 1985 \\
\text { and 2005 }\end{array}$ \\
\hline
\end{tabular}

\footnotetext{
${ }^{6}$ The electricity consumption numbers are taken from Table 2.2 in the Annual Energy Review 2005 (EIA 2006 ).
} 
Regardless of the actual method chosen, the growth rates based on supply-survey data are all considerably greater than that implied by the CBECS. The rationale for the analysis described in the remainder of this report is to try to better understand the sources of this difference in the intensity trends. We are cognizant that the supply survey-based energy consumption data are based on commercial accounts - these accounts cover more than commercial buildings. Included in these accounts are street and other outdoor lighting, municipal sanitary and water systems, and other non-building (not classified as industrial or agricultural) electricity. However, even after adjusting for this consumption as will be discussed below, the trend rate of growth from the supply survey data is much higher than that implied by CBECS over the entire time period.

As is evident in Figure 1.2, the supply-survey data suggest very rapid increases in aggregate electricity intensity during the 1990s (1.9 percent per year between 1992 and 2002). Almost as perplexing as the rapid growth in electricity intensity during this period was the sharp decline in aggregate electricity intensity in 2003 and 2004. Some of this decline can be attributed to annual variation in cooling demand in these years (2002 was hotter than normal, thus increasing consumption during the first year of the economic recession - leading to a sharp decline in 2003 when summer temperatures were more normal). Clearly, commercial energy use is tied to overall economic activity. Higher vacancy rates, shorter working hours, and less process energy use will all dampen electricity demand during an economic recession. However, casual inspection of the entire time series suggests that the decline in intensity appears to be greater than what would have been expected from the experience of the previous recessions since 1973.

Some will argue that what we may now being seeing in the annual data is the long-expected impact of more stringent building codes (with associated higher levels of equipment efficiency). A number of states adopted the ASHRAE 90.1-1989 building standard during the mid and late 1990s, in response to the Energy Policy Act of 1992. In terms of influencing intensity of the entire building stock, it is difficult to imagine that the impact, largely focused on new construction, could explain more than a small fraction of the post-2001 behavior. However, the adoption of more stringent buildings codes, namely the 90.1-1999 and 90.1-2004 standards, should start to influence the aggregate intensities at some point.

With these considerations in mind, a fundamental question needs to be answered. Given the current data collection system used by EIA, can the supply-based information related to the "commercial sector" be used as a reliable guide to what is happening in the nation's commercial buildings proper? In other words, the question is whether the commercial sector is such a "catch-all" category (with the inclusion of nonbuilding energy use) as to be not useful in showing current trends in commercial building energy intensity. An attempt to answer that question provides the motivation for the remainder of this report. 


\section{Classification Issues Related to Electricity Utility Customer Accounts}

\subsection{Utility Reported Sales collected by Supply Survey (Form EIA-861)}

Through the survey Form EIA-861, EIA collects information from over 3000 individual utilities about capacity, electricity sales (in megawatt hours [MWh]), revenues, and the number of customers. The survey has been conducted since $1984 .{ }^{7}$ EIA provides guidelines to utilities as to how to classify customer accounts by major sector. Table 2.1 defines the various customer classes in these guidelines as published in Electric Power Annual, 1994.

The top three panels of Table 2.1 show the major customer sectors--residential, commercial, and industrial. From the beginning of the survey, an "Other" sector was used to collect information for five smaller categories of service: 1) public street and highway lighting, 2) other sales to public authorities, 3) interdepartmental sales, 4) railroads and railway systems, and 5) sales under rate classes specific to irrigation electricity use. Of these five categories in the Other sector, separate data are provided for public street and highways from 1990 to 2000 in the detailed utility-specific databases posted on EIA's website. More specific definitions for the first three of the categories are provided in the bottom portion of Table 2.1 .

EIA changed the manner in which utilities reported end-use sales starting with the 2003 survey. The major change was that the "Other" sector was discontinued. The first three "Other" categories listed in Table 2.1 above are now included in the commercial sector. Electricity used for railroads and railway services is included as a separate transportation sector. Agricultural and irrigation sales, where separately identified, are included in the industrial sector. A new Transportation sector has been defined that reports electricity used by electrified rail and urban transit systems. Table 2.2 shows the electricity sales by major end use sector as published in the most recent (2004) Electric Power Annual (EIA 2005).

Table 2.3 focuses on the data related to the commercial sector. The table presents the time series estimates for both the "Old" commercial series (as shown in Table 2.2) and the series now defined by EIA. Column two of the table again shows the "Other" consumption, including transportation use that was collected in the EIA-861 through 2002. The AER commercial consumption series, shown in column four, is internally consistent with other EIA data, as can be shown by adding the "Old" commercial and "Other" sector (published in the 2004 Electric Power Annual) and subtracting transportation use as now reported in the AER. The gray-shaded portion of the table displays our rough estimates of what the "Old" commercial series might be had it been extended past 2002. It is based on our assumption that "Other" consumption (excluding transportation use) remained constant at 100 terawatt hours (TWh) for 2003 through $2005 .^{8}$

\footnotetext{
${ }^{7}$ Electricity sales data for years prior to 1984 were collected under Form EIA-826 and predecessor forms.

${ }^{8}$ The 2003-2005 estimates for both the "Old" commercial series and the current series both exclude irrigation sales, as these are now included in the industrial sector. Thus, there is remains some definitional inconsistency in the 2002 and 2003 data. Unfortunately, this period was also marked by economic recession. Furthermore, changes from one year to next in commercial consumption are influenced by weather. In Section 3.6 of the report, estimates of irrigation use consumption are developed.
} 
Table 2.1. Customer Class Definitions for Form EIA-861 (Pre-2003)

\begin{tabular}{|c|c|}
\hline Customer Service Class & Description \\
\hline Residential & $\begin{array}{l}\text { The residential sector is defined as private household } \\
\text { establishments that consume energy primarily for space heating, } \\
\text { water heating, air conditioning, lighting, refrigeration, cooking, } \\
\text { and clothes drying. The classification of an individual } \\
\text { consumer's account, where the use is both residential and } \\
\text { commercial, is based on principal use. Apartment houses are } \\
\text { included in this customer class. }\end{array}$ \\
\hline Commercial & $\begin{array}{l}\text { The commercial sector is generally defined as } \\
\text { nonmanufacturing business establishments, including hotels, } \\
\text { motels, restaurants, wholesale businesses, retail stores, and } \\
\text { health, social, and educational institutions. The utility may } \\
\text { classify commercial service as all consumers whose demand or } \\
\text { annual use exceeds some specified limit. The limit may be set } \\
\text { by the rate schedule of the utility. }\end{array}$ \\
\hline Industrial & $\begin{array}{l}\text { The industrial sector is generally defined as manufacturing, } \\
\text { construction, mining, agriculture fishing and forestry } \\
\text { establishments, Standard Industrial Classification (SIC) code } \\
01-39 \text {. The utility may classify industrial service using the SIC } \\
\text { codes, or based on demand or annual usage exceeding some } \\
\text { specified limit. The limit may be set by the utility based on the } \\
\text { rate schedule of the utility. }\end{array}$ \\
\hline $\begin{array}{l}\text { Other: Public Street and } \\
\text { Highway Lighting }\end{array}$ & $\begin{array}{l}\text { Public street and highway lighting includes electricity supplied } \\
\text { and services rendered for the purposes of lighting streets, } \\
\text { highways, parks, and other public places; or for traffic or other } \\
\text { signal system service, for municipalities, or other divisions or } \\
\text { agencies of state or federal governments. }\end{array}$ \\
\hline $\begin{array}{l}\text { Other: Interdepartmental } \\
\text { Service }\end{array}$ & $\begin{array}{l}\text { Interdepartmental service includes amounts charged by the } \\
\text { electric department at tariff or other specified rates for } \\
\text { electricity supplied by it to other utility departments. }\end{array}$ \\
\hline $\begin{array}{l}\text { Other: Other sales to public } \\
\text { authorities }\end{array}$ & $\begin{array}{l}\text { Public authority service includes electricity supplied and } \\
\text { services rendered to municipalities or divisions or agencies or } \\
\text { state or federal governments, under special contracts or } \\
\text { agreements or service classifications applicable to only to public } \\
\text { authorities }\end{array}$ \\
\hline $\begin{array}{l}\text { Other: Railroad and Railway } \\
\text { Services }\end{array}$ & $\begin{array}{l}\text { Railroad and railway services include electricity supplied and } \\
\text { services rendered to railroads and interurban and street railways, } \\
\text { for general railroad use, including the propulsion of cars or } \\
\text { locomotives, where such electricity is supplied under separate } \\
\text { and distinct rate schedules. }\end{array}$ \\
\hline $\begin{array}{l}\text { Other: Agricultural and } \\
\text { irrigation sales where } \\
\text { separately identified }\end{array}$ & As indicated by the classification. \\
\hline
\end{tabular}


Table 2.2. Electricity Sales by Sector Published in the Electric Power Annual (TWh)

\begin{tabular}{cccccc} 
Year & Residential & Commercial & Industrial & Transportation & Other \\
\hline 1990 & 924.0 & 751.0 & 945.5 & 0.0 & 92.0 \\
1991 & 955.4 & 765.7 & 946.6 & 0.0 & 94.3 \\
1992 & 935.9 & 761.3 & 972.7 & 0.0 & 93.4 \\
1993 & 994.8 & 794.6 & 977.2 & 0.0 & 94.9 \\
1994 & 1008.5 & 820.3 & 1008.0 & 0.0 & 97.8 \\
1995 & 1042.5 & 862.7 & 1012.7 & 0.0 & 95.4 \\
1996 & 1082.5 & 887.4 & 1033.6 & 0.0 & 97.5 \\
1997 & 1075.9 & 928.6 & 1038.2 & 0.0 & 102.9 \\
1998 & 1130.1 & 979.4 & 1051.2 & 0.0 & 103.5 \\
1999 & 1144.9 & 1002.0 & 1058.2 & 0.0 & 107.0 \\
2000 & 1192.4 & 1055.2 & 1064.2 & 0.0 & 109.5 \\
2001 & 1201.1 & 1088.0 & 984.5 & 0.0 & 108.4 \\
2002 & 1265.4 & 1104.7 & 990.1 & 0.0 & 105.8 \\
2003 & 1273.6 & 1197.2 & 1011.6 & 6.8 & NA \\
2004 & 1293.6 & 1229.0 & 1018.5 & 7.1 & NA
\end{tabular}

Source: Data spreadsheet downloaded from EIA web site:

http:/www.eia.doe.gov/cneaf/electricity/epa/sales_state.xls. The 1993-2004 data is shown in Table 7.2 of Electric Power Annual 2004 (EIA 2005).

For purposes of comparing the data derived from the 861 survey to those from the CBECS, at first glance we might suggest that it is appropriate to use both the "Old" AER commercial time series (i.e., excluding the "Other" series) as well as the revised series in the AER. The "Old" series excludes street and highway lighting, interdepartmental and sales to public authorities (which might be expected to contain a large portion of use for water supply and treatment), and irrigation (prior to 2003). Thus, the "Old" series might be considered a reasonable lower bound on the magnitude of consumption in commercial buildings, the scope covered by the CBECS. 
Table 2.3. Alternative Estimates of Commercial Electricity Consumption (TWh) from the Electric Power Annual (EPA) and the Annual Energy Review (AER) (Terawatt-Hours)

\begin{tabular}{|c|c|c|c|c|c|c|}
\hline Year & $\begin{array}{c}\text { ("Old") } \\
\text { Commercial } \\
(E P A \\
\text { published) }\end{array}$ & $\begin{array}{c}\text { Other (EPA } \\
\text { published) }\end{array}$ & $\begin{array}{l}\text { Transpor- } \\
\text { tation } \\
\text { (AER } \\
\text { published) }\end{array}$ & $\begin{array}{c}\text { Commercial } \\
\text { (AER } \\
\text { published) }\end{array}$ & $\begin{array}{c}\text { CBECS } \\
\text { (published) }\end{array}$ & $\begin{array}{l}\text { CBECS } \\
\text { (w/adjust.) }\end{array}$ \\
\hline 1983 & 543.8 & 80.2 & 3.7 & 620.3 & 655.6 & 707.8 \\
\hline 1984 & 582.6 & 85.2 & 4.2 & 663.7 & & \\
\hline 1985 & 606.0 & 87.3 & 4.1 & 689.1 & & \\
\hline 1986 & 630.5 & 88.6 & 4.4 & 714.7 & 700.5 & 700.5 \\
\hline 1987 & 660.4 & 88.2 & 4.6 & 744.1 & & \\
\hline 1988 & 699.1 & 89.6 & 4.7 & 784.0 & & \\
\hline 1989 & 725.9 & 89.8 & 4.8 & 810.9 & 812.7 & 812.7 \\
\hline 1990 & 751.0 & 92.0 & 4.8 & 838.3 & & \\
\hline 1991 & 765.7 & 94.3 & 4.8 & 855.2 & & \\
\hline 1992 & 761.3 & 93.4 & 4.7 & 850.0 & 764.7 & 764.7 \\
\hline 1993 & 794.6 & 94.9 & 4.8 & 884.7 & & \\
\hline 1994 & 820.3 & 97.8 & 5.0 & 913.1 & & \\
\hline 1995 & 862.7 & 95.4 & 5.0 & 953.1 & 764.4 & 807.3 \\
\hline 1996 & 887.4 & 97.5 & 4.9 & 980.1 & & \\
\hline 1997 & 928.6 & 102.9 & 4.9 & $1,026.6$ & & \\
\hline 1998 & 979.4 & 103.5 & 5.0 & $1,078.0$ & & \\
\hline 1999 & 1002.0 & 107.0 & 5.1 & 1,103.8 & 908.0 & 955.8 \\
\hline 2000 & 1055.2 & 109.5 & 5.4 & 1,159.3 & & \\
\hline 2001 & 1088.0 & 108.4 & 5.2 & $1,191.2$ & & \\
\hline 2002 & 1104.7 & 105.8 & 5.5 & $1,205.1$ & & \\
\hline 2003 & 1090.4 & 106.8 & 6.8 & $1,197.2$ & 1043.1 & 1102.6 \\
\hline 2004 & 1122.0 & 107.1 & 7.1 & $1,229.0$ & & \\
\hline 2005 & 1158.4 & 108.3 & 8.3 & $1,266.7$ & & \\
\hline
\end{tabular}

Notes:

1) EPA is the Electric Power Annual. AER is the Annual Energy Review.

2) Shaded figures from 2003 to 2005 are rough PNNL estimates

3) The CBECS adjusted figures in the last column include the estimated consumption for parking garages and commercial buildings within manufacturing complexes.

The final two columns in Table 2.3 show the commercial electricity consumption as estimated from the CBECS. As discussed previously, beginning with the 1995 CBECS, the scope of the survey was changed by eliminating parking garages and commercial buildings contained within multibuilding industrial/manufacturing complexes (primarily warehouses and offices). Based on an analysis conducted by EIA in 2002, the broader building definitional scope resulted in about a 5.8 percent larger estimate of total commercial building electricity consumption for $1992 .{ }^{9}$ In this study, we have chosen to use the older scope. This decision is prompted by several considerations. First, the supply-based commercial

\footnotetext{
${ }^{9}$ This analysis was part of an effort by EIA to compare floor space and consumption trends using all of the CBECS from 1979 through 1999. For 1992, the total published consumption was 2609 TBtu. After excluding parking garages and commercial buildings in multibuilding industrial/manufacturing complexes (which were not part of the 1995 and later CBECS), the estimated electricity consumption was $2467 \mathrm{TBtu}$. The electricity estimates are shown in webpage:http://www.eia.doe.gov/emeu/consumptionbriefs/cbecs/cbecs_trends/siteelecconsumptiondetail.html.
} 
consumption data is likely to contain most of the electricity usage for parking garages and perhaps some of the commercial buildings on manufacturing sites. ${ }^{10}$ Second, the perpetual inventory methodology used to develop the historical commercial floor space series is based on Dodge data that is likely to include newly-built floor space for most of these buildings. Thus, the published CBECS consumption estimates for 1995, 1999, and 2003 have been adjusted upward to reflect this additional building stock. ${ }^{11}$

Figure 2.1 compares the CBECS total electricity consumption estimates (adjusted for definitional change) with the two supply-based series labeled as commercial in the AER. Clearly, the trend rate of growth in commercial electricity consumption as reported from utilities is greater than that derived from the CBECS. However, over the past three cycles of the CBECS $(1995,1999$, and 2003), the rate of divergence is much smaller.

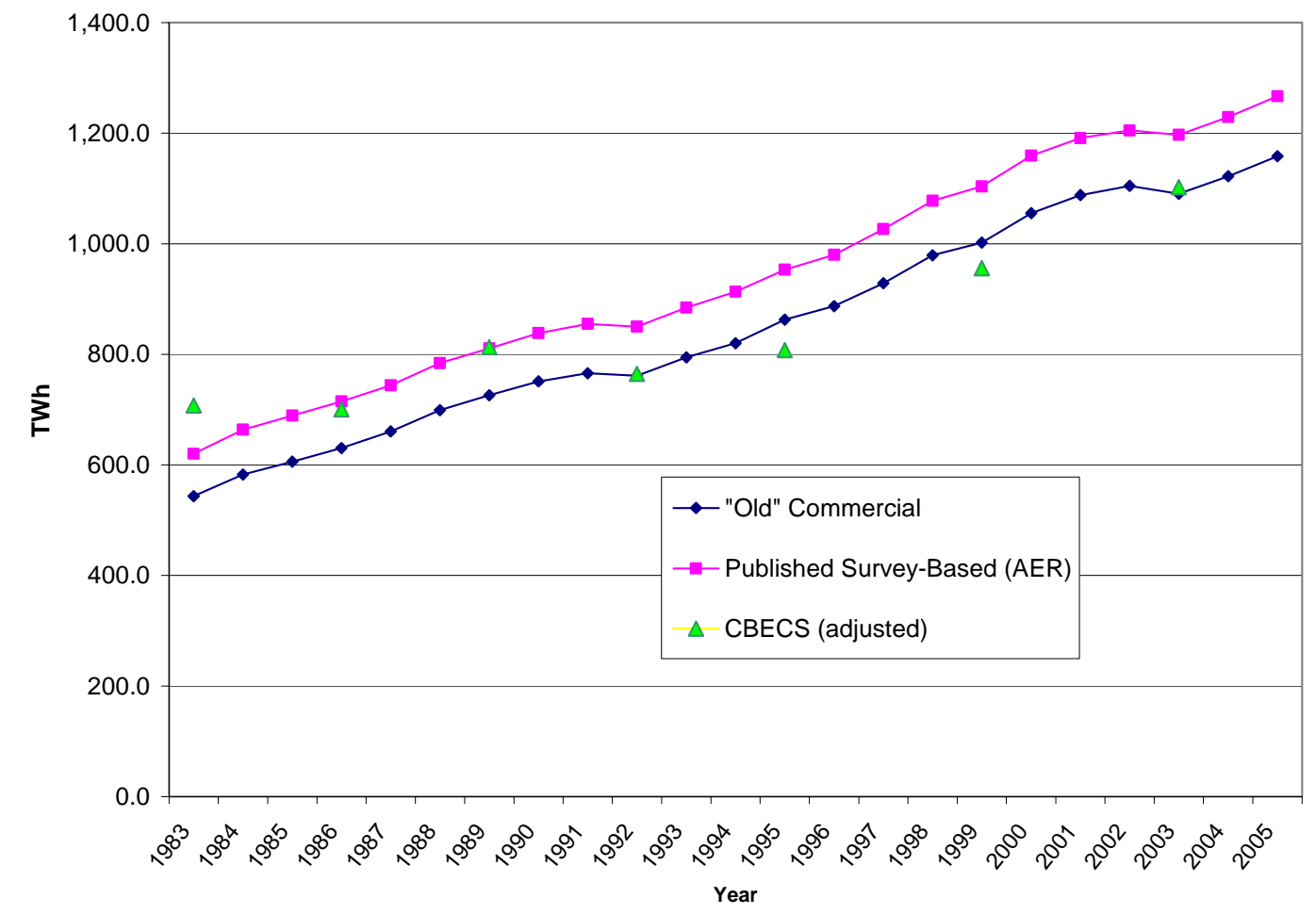

Figure 2.1. Supply-based and CBECS Estimates of Total Commercial Electricity Consumption

\footnotetext{
${ }^{10}$ In industrial or manufacturing facilities where the on-site electricity distribution is undertaken by the firm, the electricity used in commercial buildings on the site is likely to be included along with the other usage as industrial. In cases where the supplying utility handles the distribution (with separate meters to different buildings), the commercial building consumption would likely be classified as commercial. A conversation with one utility in the Northwest suggests that both types of situations exist. Based on an analysis of the micro-data for the 1992 CBECS, about $40 \%$ of the electricity used by commercial buildings in the sampled multibuilding facilities was classified by utility suppliers as commercial.
}

\footnotetext{
${ }^{11}$ The additional electricity use is computed by extrapolating the 1992 electricity consumption by the estimated increase in floor space as shown in Table 1.1. Thus, it is assumed that intensities for these buildings have not changed since 1992.
} 
Before moving to the technical discussion in the following sections, we need to acknowledge that at several times over the years, EIA has examined the differences between the supply surveys and the end use (or consumption) surveys. The most recent of these formal comparison studies was published in 1990 (EIA 1990). The section in the report related to commercial sector begins with a general description of both the Nonresidential Building Energy Consumption Survey (NBECS), as the consumption survey was termed prior to the 1989 CBECS, and the supply survey (Form-861 as will be discussed below).

For that 1990 study, the most recent comparison of electricity consumption involved the supply survey estimate as published in the State Energy Data Report (SEDR) and the 1986 NBECS. The SEDR estimate was $721 \mathrm{TWh}$ (slightly higher than the current AER published value of $714.7 \mathrm{TWh}$ for 1986 and the NBECS value of $701 \mathrm{TWh}$ ). A line item in the comparison table shows the SEDR estimate as percent of NBECS, in this case 102.9 percent. EIA noted that because the standard error of the NBECS consumption estimate was 5.4 percent, the two measures were not statistically different at the 95 percent confidence level.

While the published estimates line up relatively closely in this instance, one issue is whether they would do so if nonbuilding electricity use (excluded in the NBECS/CBECS) of electricity could be adequately estimated and deducted from the supply survey. We shall return to this topic in Section 4 of this report.

EIA does acknowledge that the "commercial sales" category in the supply survey may contain "misclassifications of high consumption apartment buildings and relatively low consuming industrial establishments which are billed at commercial rates." Offsetting these misclassifications are some commercial customers that are billed at noncommercial rates (unfortunately EIA does not provide common examples of this situation.) Taken together, the report indicates that these misclassifications "will have an unknown effect on the comparison."

As our emphasis in this study is on the differential trends in electricity consumption and intensity, the effect of these misclassifications is of most concern if they have changed significantly over time. We are aware that a common misclassification is small industrial customers billed at commercial rates. ${ }^{12}$ If the impact of this misclassification is relatively small (compared to commercial buildings strictly defined) and does not greatly change over time, then this factor will have no substantive effect of the comparison of trends.

As the next section will discuss, it appears that for some utilities, a significant number of customers have been reclassified from industrial to commercial (or vice versa) in major restructurings of rate schedules over the past decade and a half. These changes are sufficiently great to show up in the state-level

\footnotetext{
${ }^{12}$ According to the published utility-specific data available from the EIA-861 survey, in 2003 the local public utility serving most of the county in which PNNL is located showed a single industrial customer. The Census Bureau's County Business Patterns for 2003 showed 22 manufacturing establishments with 20 or more employees in the same county. Thus, in this case, clearly some small industrial sites are included in the commercial sector electricity sales. Unfortunately, extending this comparison to a state or national level did not lead to any useful results. The national number of industrial accounts (from EIA-861) is actually much greater than the number of manufacturing establishments as reported by the Census Bureau. The ratio of industrial accounts to industrial establishments (including construction and transportation along with manufacturing) varies widely by state. Thus, we must assume that for many cases, more than single account (meter) is likely to be linked to an individual industrial establishment. Examination of specific utilities and how they classify industrial accounts for the 861 survey is required to sort out this issue - an effort beyond the scope of this study.
} 
industrial and commercial consumption estimates. We will identify where these reclassifications have occurred and how we have attempted to measure their impact on the national consumption estimates.

\subsection{Classification Changes of Electric Utility Accounts: Industrial and Commercial}

A potential contributing factor in the very large growth in commercial electricity sales reported in the EIA-861 survey over the past two decades may be that some customers who formerly purchased electricity under a residential or industrial rate were subsequently switched to a "general service" or commercial rate. Typically, industrial rates are lower than commercial rates and are reserved to those customers with large (and relatively constant) electricity demands. Restructuring rate classes to put more customers into a "general service" class generally will increase utility revenue without the need for explicitly raising rates. Without trying to give a normative interpretation of this phenomenon, it may be that any shift to a rate class that is reported as commercial under EIA-861 is simply an effort to better align the utility's cost of service with its revenue. ${ }^{13}$

In analyzing the historical data by state based on EIA-861, it appears that there have been significant reclassifications of accounts, particularly between the commercial and industrial sectors, in a number of states over the past decade and a half. To help identify the most significant changes, 1990-2004 data on the number of industrial and commercial customers were plotted together for each state. Evidence of reclassification was judged, in part, on the basis of clear discontinuities in the customer counts where the change in the number of industrial customers was roughly matched by an opposite change in commercial customers. In a few cases, however, there were significant (and opposite) changes in consumption, but where the customer count changes were modest.

An examination of the state-level data for both customer counts and electricity sales resulted in the identification of eleven ${ }^{14}$ states where there appeared to be a significant reclassification between industrial and commercial accounts. ${ }^{15}$ Over the past decade or so, reclassifications between these two end-use sectors tended to increase commercial sector sales and reduce industrial sector sales.

Although a small share of national electricity, the data for New Hampshire provide a clear example of a reclassification, as shown in Figure 2.2. The reduction in industrial electricity between 1993 and 1994 is mirrored with a similar increase in commercial use between the same two years.

\footnotetext{
${ }^{13}$ We must admit as well that without direct investigation as to how utilities respond to the 861 survey, it may be just that over time utilities have reported the consumption from more rate classes as "commercial" and fewer as "industrial." Thus, a reclassification in the context of this report need not involve customers actually facing a different rate schedule over time, but that the rate schedules are classified and aggregated differently for reporting to EIA.

${ }^{14}$ Twelve states are shown in Figures 2.2 through 2.6 below. Idaho is included in Figure 2.3, but the discontinuity in 2004 owes only to the reclassification of irrigation sales to industrial as discussed in Section 2.1 Thus, it is shown as a case where there is large discontinuity in the published state data, but it is not due to an actual reclassification between industrial and commercial customers.

15 The discussion below gives no specific details as to how and why these reclassifications occurred in particular states. Unfortunately, the key EIA analyst who was most familiar with these data no longer works in the agency.
} 


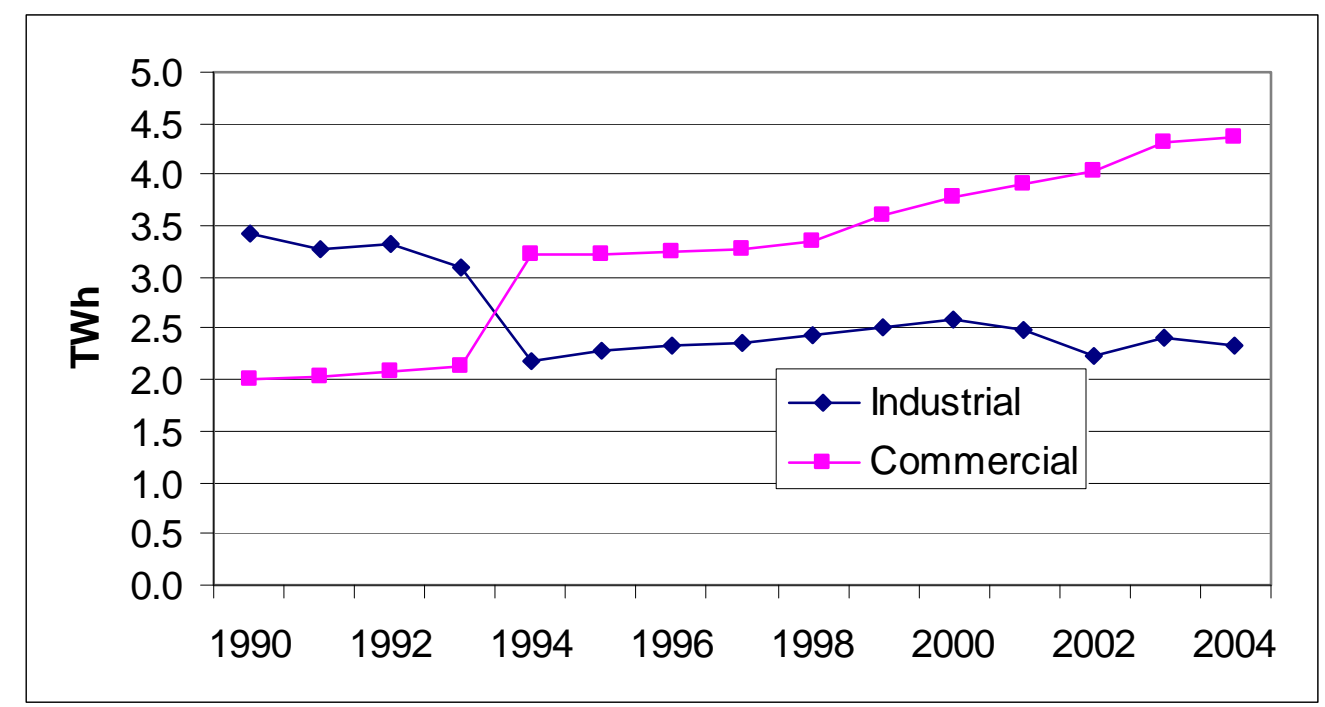

Figure 2.2. Reported Commercial and Industrial Electricity for New Hampshire, 1990-2004

The purpose of examining these major reclassifications primarily is to determine if they play any significant role in explaining the very high growth in commercial sector electricity sales over the past decade and a half. To meet that objective, we need only try to maintain what would be a consistent classification framework over time. We can meet the second objective by trying to keep the commercial sales consistent with the classification framework either before or after the reclassification. For example, for New Hampshire, we either show that commercial sales over the entire period are greater than 3 terawatt hours (TWh) (consistent with the post-1993 classification), or that the sales are 2 TWh in 1990 and grow in a smooth path after that.

Ideally, we would like to identify the choice that would yield a closer match to the amount of electricity actually used by commercial buildings. Unfortunately, without detailed examination of the specific utilities for which these reclassifications took place and how their rate classes are defined, we have no clear evidence on which to make a particular choice. For this study, we have attempted to estimate the consumption series using two methods. In method A, we have generally chosen to maintain the commercial time series consistent with the earlier classification. This has the advantage that we need only adjust the more recent commercial sales data, rather than going all the way back to the early and mid1980s to construct a consistent time series. An exception to this treatment is for the state of Tennessee. As will be discussed below, it is clear in that case that a more reasonable representation of commercial sector sales is shown by the most recent data. Another special case is the District of Columbia, where the most recent data in our judgment shows the more accurate accounting of commercial sales.

For the second method (B), we have attempted to estimate what commercial and industrial might have been in earlier years using the most recently observed classification. Because many of the reclassifications occurred in the mid to late $1990 \mathrm{~s}$, this method is likely to involve more uncertainty as we need to adjust more years of data. Nevertheless, if we presume that the most recent reporting of commercial and industrial sales portrays a more accurate distribution between these two sectors, then method B is to be preferred, in spite of the need to make adjustments over a longer time period. 
For both methods, the procedure to try to achieve consistent time series of end-use consumption data involves two elements. The first element focuses on the industrial sector and seeks to estimate what industrial sales would have been had there been no reclassification in a particular year. Typically, the predicted change in sales for those years for which the reclassification appears to have occurred was made by simply applying the same absolute change as observed in the prior year. Thus, we have for the predicted change in industrial sales in year $\mathrm{t}$

$$
[\mathrm{I}(\mathrm{t})-\mathrm{I}(\mathrm{t}-1)] \mathrm{P}=[\mathrm{I}(\mathrm{t}-1)-\mathrm{I}(\mathrm{t}-2)]
$$

where $I(t)=$ industrial sales in year $t$ (year $t$ is identified as one in which a reclassification occurs), and the superscript $\mathrm{P}$ refers to the predicted change.

For Method A, the estimated amount of industrial electricity sales reclassified is defined is the difference between the reported change (including the reclassification) less the extrapolated (predicted) change defined in Equation (2.1). Thus, the second element of the method is to define the reclassified industrial sales as

$$
R(t)=[I(t)-I(t-1)] P-[I(t)-I(t-1)] R
$$

The value of reclassified sales, $\mathrm{R}(\mathrm{t})$, is held constant for all subsequent years. Thus, if the reclassification occurs in year $t^{*}$, then $\mathrm{R}(\mathrm{t})=\mathrm{R}\left(\mathrm{t}^{*}\right)$ for $\mathrm{t}>\mathrm{t}^{*}$. The industrial and commercial sales are then adjusted by adding or subtracting this constant consumption from the values reported via EIA-861:

$$
\begin{aligned}
& I(t)=I(t)^{r}+R\left(t^{*}\right) \\
& C(t)=C(t)^{r}-R\left(t^{*}\right)
\end{aligned}
$$

$$
\begin{array}{rll}
\text { where } \mathrm{I}(\mathrm{t}) & = & \text { (adjusted) industrial electricity sales in year } \mathrm{t} \\
\mathrm{I}(\mathrm{t})^{\mathrm{r}} & = & \text { reported industrial electricity sales in year } \mathrm{t} \\
\mathrm{C}(\mathrm{t}) & = & \text { (adjusted) commercial electricity sales in year } \mathrm{t} \\
\mathrm{C}(\mathrm{t})^{\mathrm{r}} & = & \text { reported commercial electricity sales in year } \mathrm{t} .
\end{array}
$$

In method B, we attempt extrapolate to prior years the amount of this reclassified electricity. Motivating this method, we assume that by going back as far as 1980, it is not reasonable to believe that the reclassified electricity would be constant over time. Not having any special information on the characteristics of these users whose classification changed, we have assumed that the magnitude of the reclassified electricity use is proportional to the sum of industrial and commercial electricity sales. Formally, in method B, we adjust industrial and commercial electricity sales as follows:

$$
\begin{aligned}
& \mathrm{I}(\mathrm{t})=\mathrm{I}(\mathrm{t})^{\mathrm{r}}+\mathrm{R}\left(\mathrm{t}^{*}\right) x\left[\mathrm{I}(\mathrm{t})^{\mathrm{r}}+\mathrm{C}(\mathrm{t})^{\mathrm{r}}\right] /\left[\mathrm{I}\left(\mathrm{t}^{*}\right)^{\mathrm{r}}+\mathrm{C}\left(\mathrm{t}^{*}\right)^{\mathrm{r}}\right] \\
& \mathrm{C}(\mathrm{t})=\mathrm{C}(\mathrm{t})^{\mathrm{r}}+\mathrm{R}\left(\mathrm{t}^{*}\right) x\left[\mathrm{I}(\mathrm{t})^{\mathrm{r}}+\mathrm{C}(\mathrm{t})^{\mathrm{r}}\right] /\left[\mathrm{I}\left(\mathrm{t}^{*}\right)^{\mathrm{r}}+\mathrm{C}\left(\mathrm{t}^{*}\right)^{\mathrm{r}}\right]
\end{aligned}
$$


To be clear, the adjustments using method B defined in equations (2.4a and $2.4 \mathrm{~b})$ are made only for years prior to the reclassification. The data for the reclassification and subsequent years is not changed. For method A, defined in terms of equations (2.3a and 2.3b), the adjustment is made for the reclassification year and later years - data from earlier years are unaffected.

Figures 2.3 through 2.5 show ten additional states that indicate a significant reclassification was made in a particular year. In the top left panel of Figure 2.3, the reclassification for Alabama occurs in 1997 where commercial sales show a sharp increase and industrial sales fall. For Colorado and Idaho, the reclassification works in the other direction-increasing industrial sales while reducing commercial. For Colorado, the number of industrial customers reported in the 861 survey by the Public Service Company of Colorado, the largest utility in the state, increased from 158 to 377 between 1993 and 1994. This more than doubling of industrial accounts reflects some restructuring of rate schedules that led to more reported industrial electricity sales.

For Idaho, the abrupt changes in 2004 for industrial and commercial consumption are due to the change in reporting of irrigation sales from "Other" to industrial, as described in the previous section. That change is reflected in the number of "industrial" customers increasing from less than 200 in 2003 to more than 15,000 in 2004. In Section 3 below, we handle irrigation sales as an overall adjustment to commercial electricity use. Thus, we do not separately make a reclassification adjustment for Idaho in order to avoid double counting.

For the District of Columbia, we have assumed that the reclassification that occurred in 1994 is more indicative of the relative sales between commercial and industrial customers. It is likely that large federal facilities received an "industrial" rate prior to 1994. For this series, we have converted all of the historical data (1980-1993) to be consistent with the 1994 and later classification. In this particular instance, the industrial electricity consumption between 1980 and 1993 was assumed to be the same as the 1994 value. Commercial electricity use is then calculated as the difference between the reported total (industrial + commercial) electricity use and this fixed value.

In the top left panel of Figure 2.4, commercial sales in Maryland nearly doubled in 1995, but a subsequent reclassification in 2002 tended to roughly reverse the effects of the earlier classification change. Large reclassifications from industrial to commercial sales occurred in Michigan in 1993 and in Minnesota in 2001. A smaller reclassification occurred in 1997 in Mississippi. 

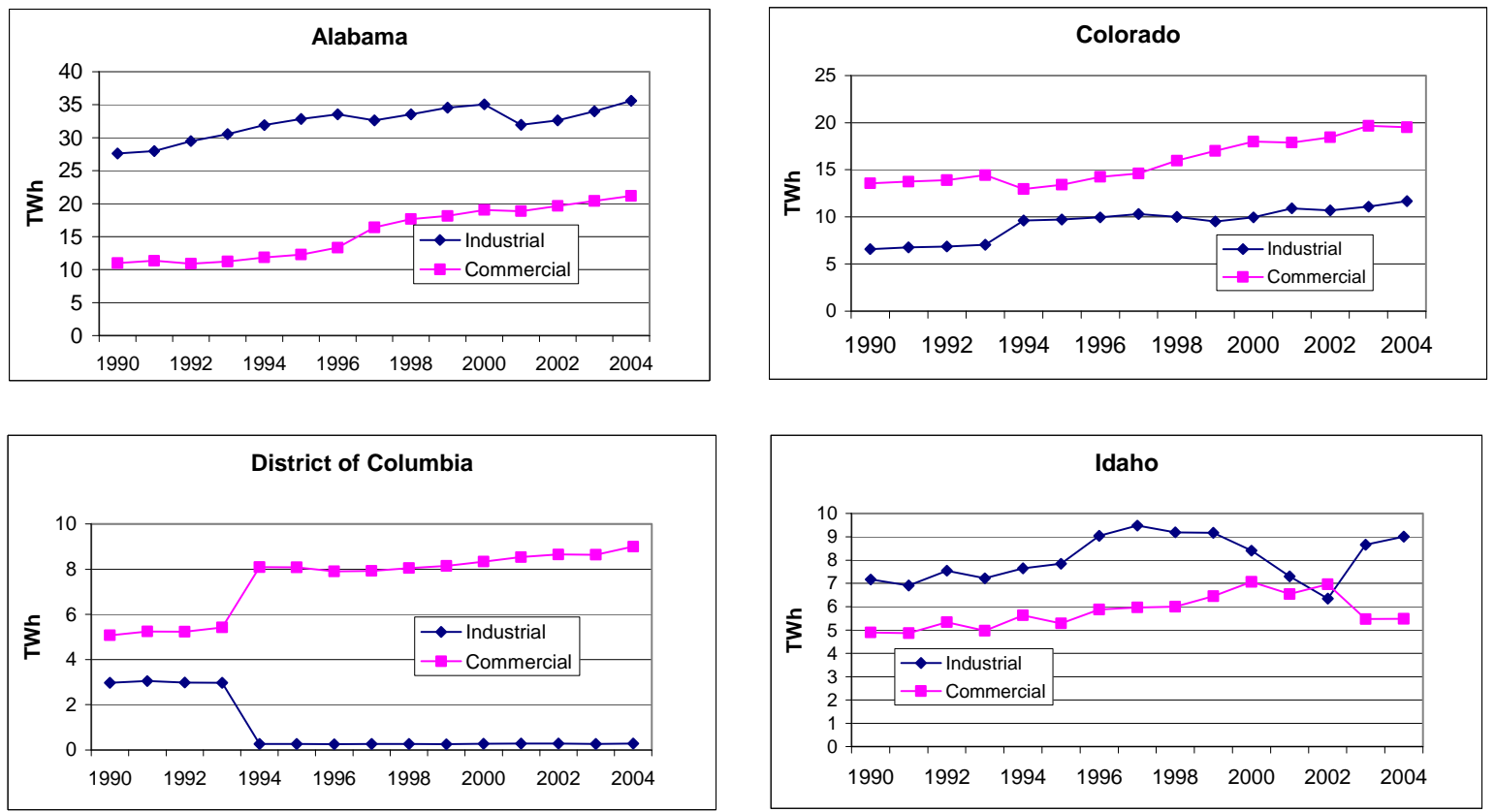

Figure 2.3. Commercial and Industrial Electricity Sales: Alabama, Colorado, District of Columbia, and Idaho.
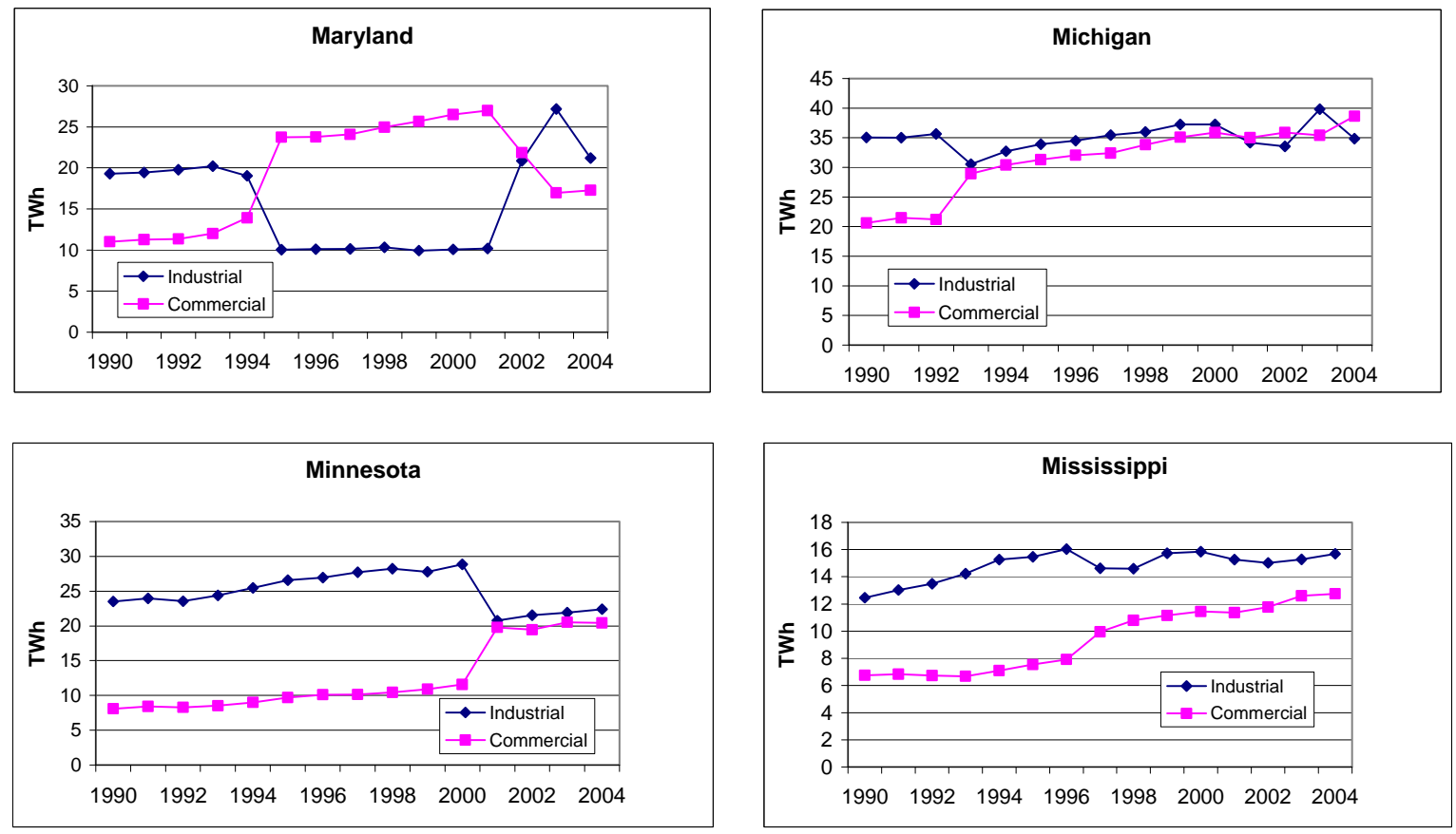

Figure 2.4. Commercial and Industrial Electricity Sales: Maryland, Michigan, Minnesota, and Mississippi. 

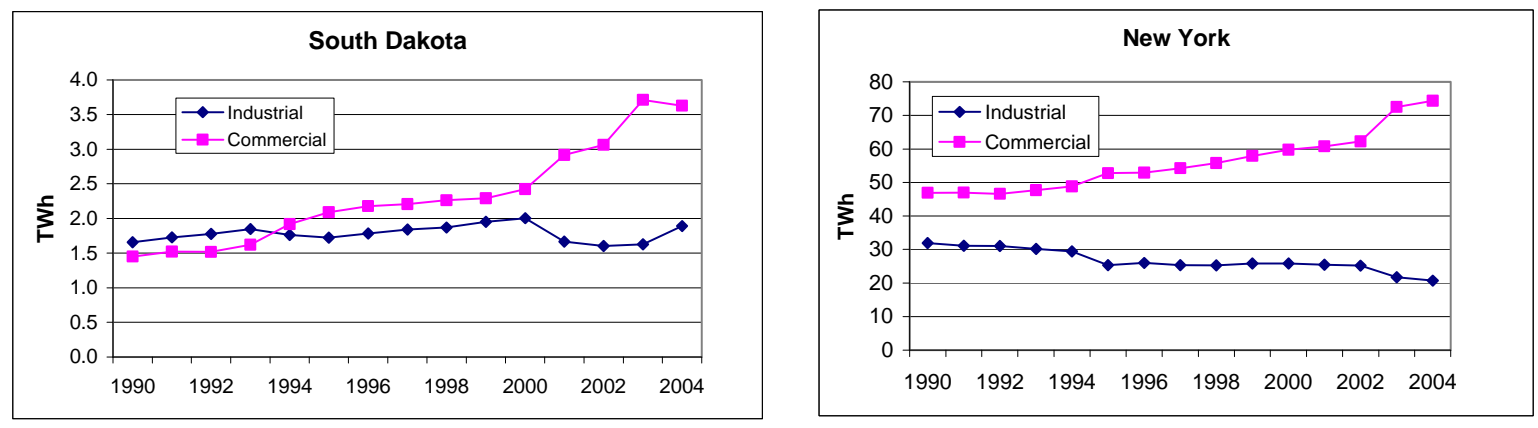

Figure 2.5. Commercial and Industrial Electricity Sales: South Dakota and New York.

Figure 2.5 plots the historical commercial and industrial electricity growth in South Dakota and New York. In South Dakota, reported commercial sales increased sharply in 2001, while industrial sales fell by about the same magnitude (the increase in from 2002 to 2003 reflects the incorporation of "Other Sales" into the commercial category.) Discernable discontinuities in both the commercial and industrial series occur in 1994 in New York, reflecting some reclassification actions. (As with South Dakota, the sharp increase in commercial construction in 2003 was not adjusted as it likely due to the addition of the Other" category for the first time in that year).

However, the largest magnitudes of reclassification activity over the past several decades have occurred between commercial and industrial accounts in Tennessee. In this state, we have exploited the longer time series estimates developed by EIA as part of their State Energy Data System (SEDS). This information is based on EIA-861 data, except that the commercial sector consumption series incorporates the "Other sales" data, and excludes the estimates of transportation electricity use. For this study, these data were available through $2003 .{ }^{16}$

The left panel of Figure 2.6 shows that perhaps as many as three separate reclassifications have occurred over the past two decades in Tennessee - in 1984, 1992, and 1997. The first two of the reclassifications resulted in significant year-to-year declines in commercial sales. The major reclassification in 1997 resulted in an apparent four-fold increase in commercial sales.

When looking at the left panel of Figure 2.6, a reasonable adjustment would suggest that we accept the pre-1984 and post-1997 commercial sales as the most accurate measures of commercial sales (with the bulk of sales to commercial buildings.). Thus, we have attempted to link the 1983 and 1997 points with a rough interpolation. For period 1984 through 1992, we have used growth of the published series as shown in the left panel. Between 1992 and 1997, the data are incongruous. The published data are around 5

\footnotetext{
16 The consumption data in physical units for all energy forms by state are available from the following website: http://www.eia.doe.gov/emeu/states/_seds.html. For the period 1990 through 2003, the state-level estimates from the SEDS database are equivalent to the Commercial + Other Sales series from the Form 861 data, but are smaller in some states reflecting the exclusion of transportation electricity use. The sum of the electricity sales across the states matches the national totals shown in Table 2.1c in the Annual Energy Review. For examining the reclassification across all of the states, we generally focused on the Form-861 data as it extended through 2004 and the fact that the commercial series did not include any distortion from potential irregularities in the "Other Sales" series.
} 

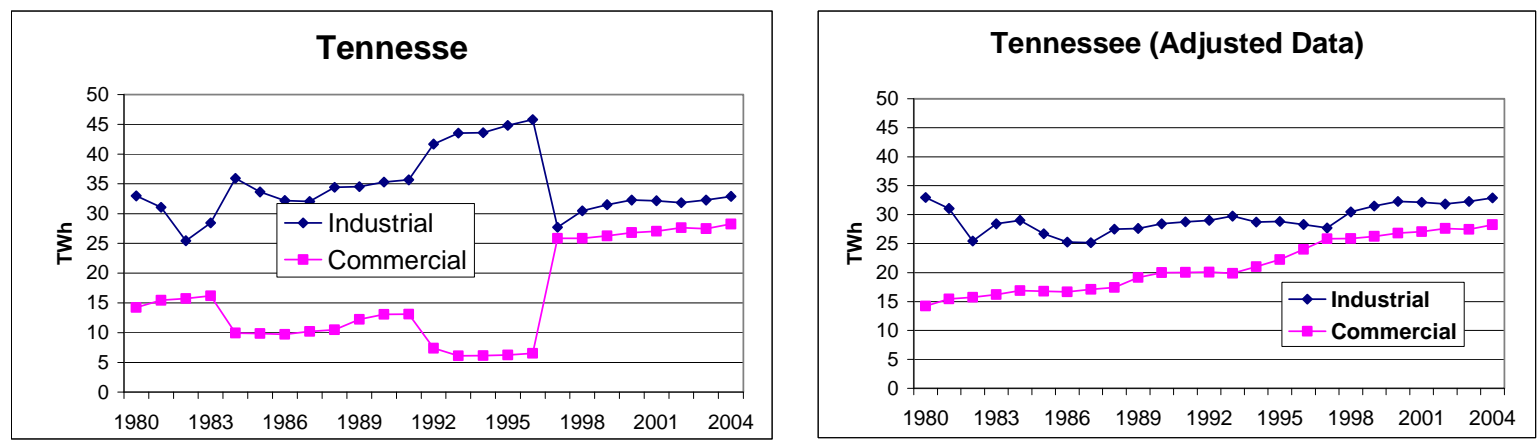

Figure 2.6. Classification Changes between Industrial and Commercial Sectors for Tennessee, 1980-2004

TWh, with little change over that time period. As a result we inserted a set of "add" factors that change by year that roughly smooth the time series over this period (1992-1996) and thus yield a relatively smooth interpolating series. The result is fairly rapid, but steady, growth in commercial sales over this period; we have no information that might suggest a different growth path.

Finally, the situation in California is somewhat different from that in states where reclassification between industrial and commercial accounts appears to have occurred. In the wake of the electricity crisis during 2000 and early 2001, the state of California used the California Department of Water Resources (CDWR) as an agency to broker electricity sales between generators and retail customers. This step was designed to bring more stability (and lower prices) to retail electricity markets in the state. Although required to report under EIA-861, CDWR did not classify their user accounts in the same manner as the previous suppliers. EIA recognized this problem and, in 2004, reassigned some $5 \mathrm{TWh}$ from the commercial to industrial sector

The left panel of Figure 2.7 shows the recent historical pattern of commercial and industrial sales in California (which incorporates the adjustment made by EIA). In this instance, we have chosen to plot the consumption reported in the SEDS - thus including the "Other" category except for transportation in the commercial sector. In spite of the adjustments made by EIA, the growth in commercial sales after 2001 still appears to be overstated. A further adjustment of $3 \mathrm{TWh}$ (from commercial to industrial) was made for the years 2001 through 2005. This adjustment basically moderates the very high increase in reported commercial sales from 2000 to 2001, and makes the adjusted increase more comparable to that between 1999 and 2000. ${ }^{17}$ With that adjustment, the revised commercial and industrial sales are shown on the right panel in Figure 2.7. By means of visual inspection, the trend in commercial sales in the most recent years now appears to be roughly the same as that observed in the last half of the 1990 's. ${ }^{18}$

\footnotetext{
${ }^{17}$ The sharp increase in the reported commercial consumption between 2000 and 2001 is not likely due to weather conditions. Total cooling degree-days for the Pacific census division did increase by about $5 \%$ between 2000 and 2001 , but this is not sufficient to account for the magnitude of the reported growth in commercial consumption of 9.3\% (as compared to the 7.3\% growth between 1999 and 2000). We also looked at total service sector employment in California over this period. Annual service sector employment grew by $3.6 \%$ between 1999 and 2000 but by only $1.1 \%$ between 2000 and 2001 . Thus, it seems inconsistent that the reported commercial consumption would have increased by over $8 \%$ in 2001 from the previous year.

${ }^{18}$ The decline in 2003 is consistent with the decline in national commercial electricity use and is likely due to weak economic conditions.
} 

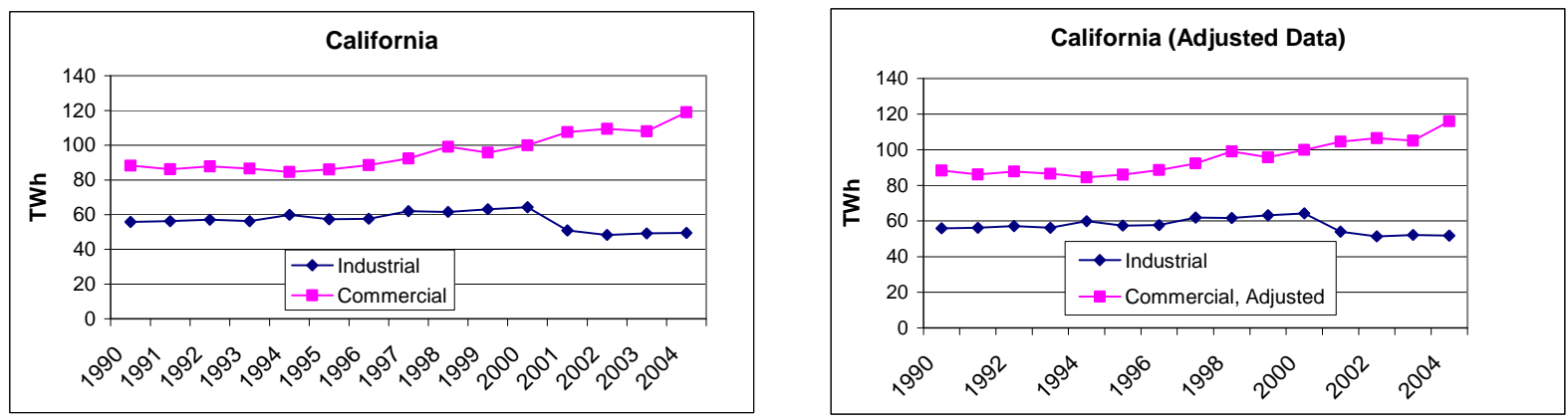

Figure 2.7. Industrial and Commercial Electricity Sales in California

Table 2.4 shows the published commercial consumption (from the Annual Energy Review 2005) and the total adjustments based upon methods $\mathrm{A}$ and $\mathrm{B}$. The total adjustments for 2005 were assumed to be the same as for 2004. Using method A, the maximum adjustment is a reduction of about 33 TWh in 2001. Most of the positive adjustments in the 1980s result from adjusting the Tennessee commercial sales to produce a smooth trend between 1984 and 1987 (as shown in Figure 2.6). For method B, the adjustments in the 1980s are much larger, reflecting the fact that most of the subsequent reclassifications moved sales from the industrial to the commercial sector. By 2004 and 2005, the only remaining adjustment is that for California, where we argued that commercial electricity may be overstated in the range of $3 \mathrm{TWh}$. 
Table 2.4. Total Commercial Electricity Consumption Adjusted for Reclassifications (Terra-watt hours)

\begin{tabular}{|c|c|c|c|c|c|}
\hline Year & $\begin{array}{c}\text { Published } \\
\text { (Supply } \\
\text { based) } \\
\text { AER }\end{array}$ & $\begin{array}{l}\text { Reclassifi- } \\
\text { cation } \\
\text { Adjustment } \\
\text { Method A }\end{array}$ & $\begin{array}{c}\text { Adjusted } \\
\text { Series }\end{array}$ & $\begin{array}{l}\text { Reclassifi- } \\
\text { cation } \\
\text { Adjustment } \\
\text { Method B }\end{array}$ & $\begin{array}{c}\text { Adjusted } \\
\text { Series }\end{array}$ \\
\hline 1980 & 558.6 & 0.0 & 561.7 & 16.0 & 574.6 \\
\hline 1981 & 595.9 & 0.0 & 599.0 & 16.3 & 612.2 \\
\hline 1982 & 608.7 & 0.0 & 611.9 & 15.5 & 624.3 \\
\hline 1983 & 620.3 & 0.0 & 623.6 & 16.5 & 636.7 \\
\hline 1984 & 663.7 & 9.1 & 672.8 & 23.2 & 686.8 \\
\hline 1985 & 689.1 & 9.2 & 698.3 & 23.5 & 712.6 \\
\hline 1986 & 714.7 & 9.3 & 724.0 & 23.7 & 738.4 \\
\hline 1987 & 744.1 & 9.4 & 753.4 & 24.7 & 768.7 \\
\hline 1988 & 784.0 & 9.5 & 793.5 & 25.8 & 809.8 \\
\hline 1989 & 810.9 & 9.6 & 820.4 & 26.2 & 837.1 \\
\hline 1990 & 838.3 & 9.6 & 847.9 & 26.6 & 864.8 \\
\hline 1991 & 855.2 & 9.7 & 864.9 & 26.9 & 882.1 \\
\hline 1992 & 850.0 & 15.4 & 865.4 & 32.5 & 882.5 \\
\hline 1993 & 884.7 & 10.8 & 895.5 & 28.4 & 913.1 \\
\hline 1994 & 913.1 & 9.5 & 922.6 & 27.5 & 940.6 \\
\hline 1995 & 953.1 & -1.8 & 951.3 & 16.7 & 969.8 \\
\hline 1996 & 980.1 & -0.3 & 979.7 & 18.5 & 998.5 \\
\hline 1997 & $1,026.6$ & -21.4 & $1,005.3$ & -2.6 & $1,024.0$ \\
\hline 1998 & $1,078.0$ & -21.4 & $1,056.6$ & -2.4 & $1,075.5$ \\
\hline 1999 & $1,103.8$ & -21.4 & $1,082.5$ & -2.4 & $1,101.4$ \\
\hline 2000 & $1,159.3$ & -21.4 & $1,138.0$ & -10.1 & $1,149.2$ \\
\hline 2001 & $1,190.9$ & -32.8 & $1,158.2$ & -13.1 & $1,177.8$ \\
\hline 2002 & $1,205.0$ & -27.1 & $1,177.9$ & -7.5 & $1,197.5$ \\
\hline 2003 & $1,197.2$ & -26.0 & $1,171.2$ & -3.0 & $1,194.2$ \\
\hline 2004 & $1,229.0$ & -24.7 & $1,204.4$ & -3.0 & $1,226.0$ \\
\hline 2005 & $1,266.7$ & -24.7 & $1,242.0$ & -3.0 & $1,263.7$ \\
\hline
\end{tabular}

Figures 2.8 and 2.9 show the total effect of the reclassifications using methods A and B, respectively. Using either method the growth rates of total commercial consumption based upon the adjusted series are lower than that of the published series. Between 1985 and 2005, the annual growth rate of the published series is $3.09 \%$ per year. Using method A, the growth rate of the adjusted series is $2.92 \%$. For method B, the growth is very slightly lower at $2.91 \%$ per year. Thus, in terms of growth, it makes little difference as to which adjustment method is employed. Using either method, the adjusted series grows about $6 \%$ less over this period as compared to the published series. While not large, the reclassifications that we are able to observe do play a small role in driving the high growth rate of electricity consumption suggested by the supply surveys. 


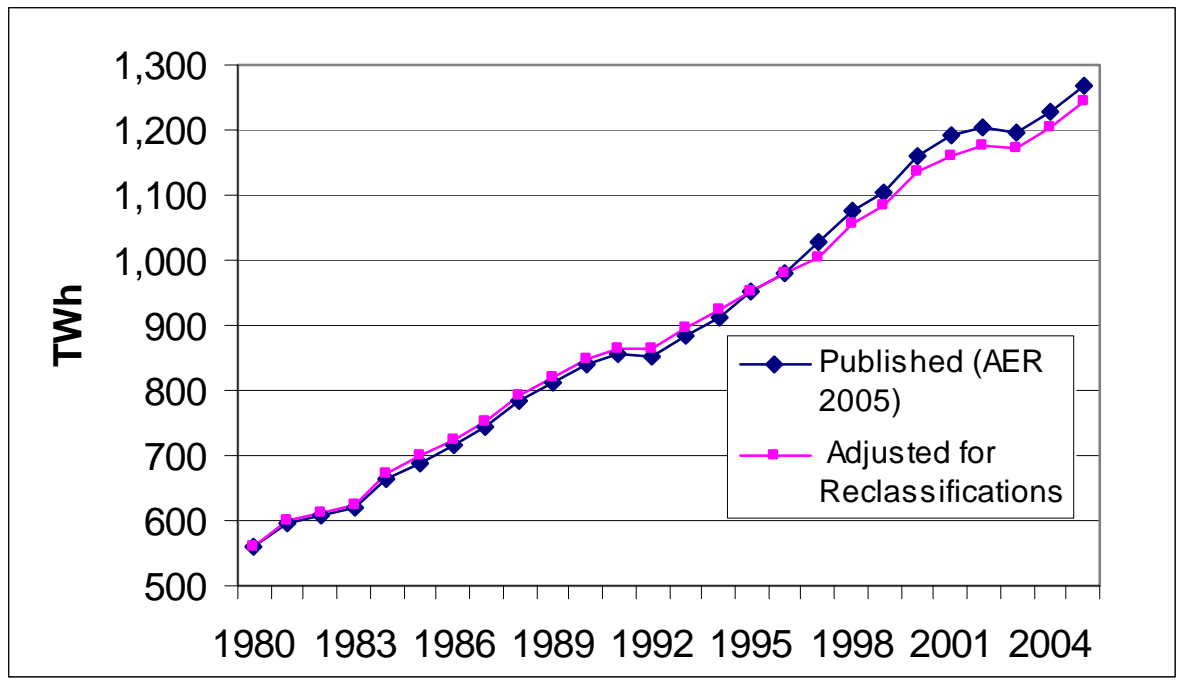

Figure 2.8. Published and Adjusted Total Commercial Electricity Sales (Method A)

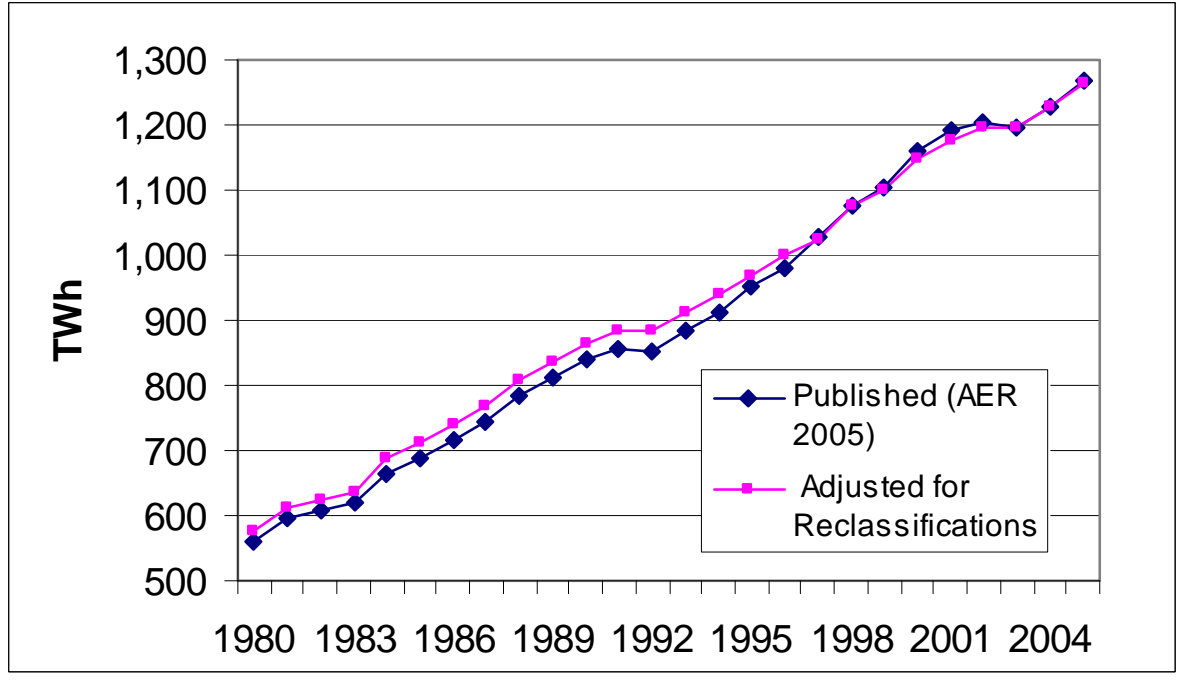

Figure 2.9. Published and Adjusted Total Commercial Electricity Sales (Method B) 


\section{Non-Enclosed Equipment}

A major aspect of the difference between the CBECS and the EIA-861 supply survey is that various categories of equipment not contained in buildings are reported in the latter source, but not in the former. This section develops detailed estimates of electricity used by the major types of equipment not covered in the CBECS. The first three sections discuss different end uses for outdoor lighting: street and highway lighting, parking lot lighting, and traffic signals. Section 3.4 takes an extended look at water supply and treatment facilities. Section 3.5 explores whether the electricity used to support a major new communication technology - cell phone towers - is sufficient to affect aggregate use trends. A final section looks at electricity used for irrigation - an end use that was classified with other commercial electricity in the EIA-861 until 2004.

The types of equipment discussed in the following sections do not represent an exhaustive list of nonenclosed equipment in the commercial sector. To cite a few specific omissions, the report does not cover the operation of bridges, outdoor recreational facilities (e.g., amusement parks, ski areas, golf driving ranges), or cable TV or microwave equipment for communications (other than cell phone sites). Development of data and methods to estimate the electricity use in these uses was beyond the scope of this specific study. Our assumption is that the aggregate amount of electricity used in this equipment is relatively small compared to those equipment types for which estimates can be made.

\subsection{Street and Highway Lighting}

As any motorist can readily observe, lighting of streets and highways constitutes a large use of electricity in the U.S. One recent report has indicated that there may as many as 60 million street lights illuminating the nation's streets and highways. While classified as commercial use, none of this electricity is covered by the CBECS.

The estimates for street and highway lighting are based on a combination of two sources. The first source relies on reported electricity use by utilities through the 861 supply survey. Because not all utilities maintain a separate classification for street and highway lighting, an imputation procedure was conducted to estimate the amount of lighting electricity use for non-reporting utilities. The second source was a recent report on lighting use in the U.S. conducted by Navigant Consulting for the Office of Energy Efficiency and Renewable Energy (EERE)/Building Technologies (BT) (Navigant Consulting 2002). The Navigant report developed an estimate of total national electricity use for street and highway lighting based on an inventory of street lamps and estimates of unit consumption.

\subsubsection{Street and Highway Lighting from EIA-861.}

From 1990 through 2000, the EIA asked for utilities to separately report electricity sales for public street and highway lighting via survey EIA-861. ${ }^{19}$ The utility-level data for 1997 was analyzed in some detail to try to assess the value of this information.

Out of the approximately 3200 utilities reporting under EIA-861, about 1700 provide a non-zero value for electricity sold for street lighting. One can presume that these 1700 utilities defined a separate rate class for street lighting.

\footnotetext{
${ }^{19}$ For the remainder of this section, "street lighting" will refer to both street and highway lighting for public use.
} 
To develop a comprehensive estimate of street and highway lighting, we need some method of imputing the amount of such usage for the roughly 1500 utilities with no separate breakout for this use. To begin an imputation method, it seems reasonable to start with an assumption that the amount of street lighting would be roughly proportional to the number of residential electricity customers (also reported through EIA-861). Given that line of reasoning, Figure 3.1 plots the annual $\mathrm{kWh}$ per customer by the number of customers in each reporting utility. ${ }^{20}$ With the exception of very small utilities, the values appear to generally cluster between 100 and $300 \mathrm{kWh}$ per residential customer per year.

The very high values in the small utilities (categorized somewhat arbitrarily as fewer than 10,000 customers) are perplexing. In perusing the list of approximately 70 utilities with values greater than 1000 $\mathrm{kWh}$ per customer, almost all were municipal systems in very small towns. One might speculate that electricity for other uses besides lighting may be included in the reported lighting figures, but it not clear why that bias would be more prevalent in these small towns as compared to larger utility service areas. The more likely explanation is simply that lighting in the few major streets ("main street") in these small towns represents a relatively high load relative to the number of residents.

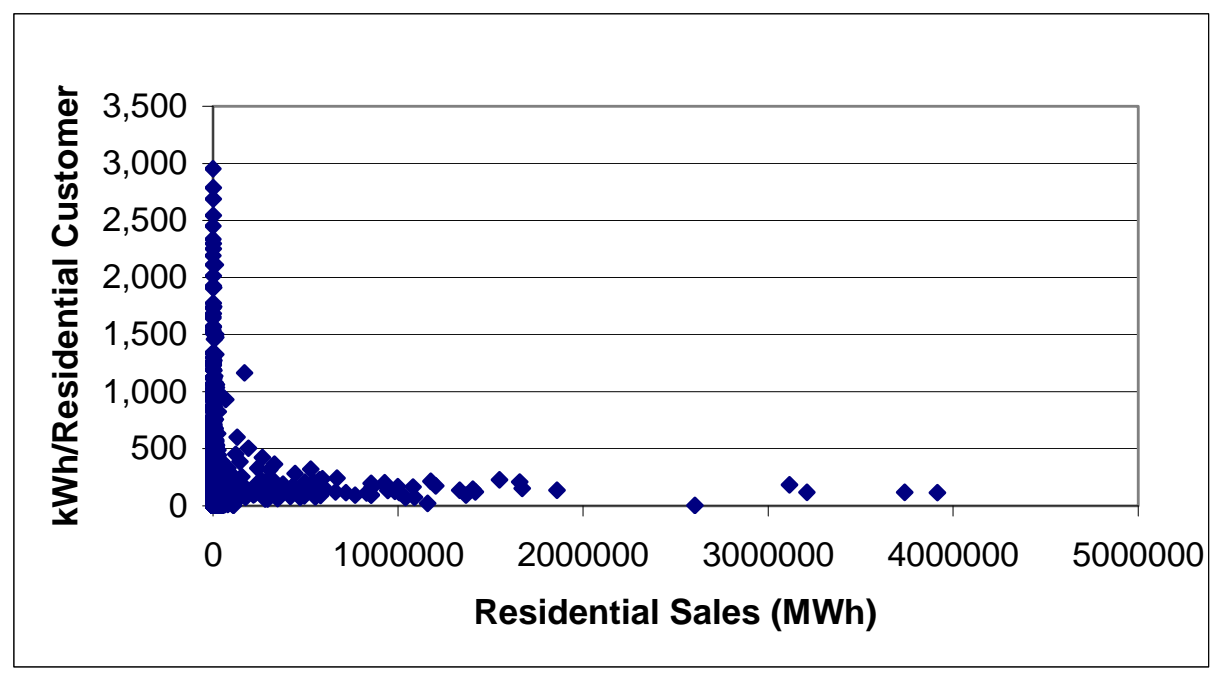

Figure 3.1. Electrical Consumption per Residential Customer and Number of Customers, 1997

As nearly 1500 utilities did not report any separate values for street lighting, an effort was made to impute electricity for those non-reporting utilities. A simple regression model was estimated using the following general specification:

$$
\text { Electricity Use }=\mathrm{f}\left(\mathrm{RC}, \mathrm{RC} 2, \mathrm{CR} \_ \text {ratio }\right)
$$

where

$$
\mathrm{RC}=\text { number of residential customers }
$$

\footnotetext{
${ }^{20}$ In the plot, the upper limit of $\mathrm{kWh} /$ residential customer was set at 3000. There were six utilities in 1997 in which this limit was exceeded.
} 


$$
\text { CR_ratio = ratio of commercial electricity consumption to residential consumption }
$$

This model was separately estimated for large utilities ( $>10,000$ residential customers) and small utilities $(<10,000$ residential customers). The ratio of commercial electricity sales to residential sales was included to help distinguish between utilities serving primarily urban areas and those in rural areas (i.e. Rural Electrification Associations and other cooperatives).

Table 3.1 summarizes the results of this imputation process. The table shows four separate categories for the 3190 utilities reporting on EIA-861 in 1997. For 193 utilities, no residential accounts were reported, but a total of 462,273 MWh was nevertheless reported for street lighting. Six utilities reported an extremely high consumption per residential customer $(>3000 \mathrm{kWh})$ and these values were omitted in the sample used to estimate the imputation models.

The third line in Table 3.1 shows the street lighting consumption reported by the 1727 utilities reporting a non-zero value for this end use. The average use per residential customer was $152 \mathrm{kWh}$; the variation around that figure is shown in Figure 3.1.

Table 3.1. Estimates of Total Street Lighting Electricity Use for 1997, Based on EIA-861

\begin{tabular}{lcccrc} 
Utility Segment & $\begin{array}{c}\text { No. of } \\
\text { Utilities }\end{array}$ & No. of Accts & $\begin{array}{c}\text { MWh } \\
\text { (actual) }\end{array}$ & \multicolumn{1}{c}{$\begin{array}{c}\text { MWh } \\
\text { (pred.) }\end{array}$} & kWh/Acct \\
\hline No Residential Accts & 193 & NA & 462,273 & 462,273 & NA \\
High Intensity & 5 & 20,911 & 126,851 & 126,851 & 6,066 \\
Sample, reported lighting & 1,728 & $97,043,083$ & $14,759,228$ & $14,759,830$ & 152 \\
Imputed, no reported lighting & 1,264 & $5,075,398$ & NA & $1,023,265$ & 202 \\
\hline & 3,190 & $102,139,392$ & & $16,372,219$ &
\end{tabular}

The 1264 utilities that did not report any street lighting on the EIA survey accounted for only about 5 million residential customers, as shown in the last line of the table. Using the regression model defined in Equation (3.1), the total imputed electricity use was about 1 million MWh. Consistent with the plot in Figure 3.1, the average use per customer in these smaller, non-reporting utilities was imputed to be higher than the average for the reporting utilities. As shown in the last column of the table, the average annual consumption per residential customer was predicted by the regression models to be about $200 \mathrm{kWh}$.

The street and highway lighting electricity sales data were collected from the detailed EIA-861 database files for selected years between 1990 and 2000. For the intervening years where PNNL did not explicitly analyze the data, estimates were developed by linear interpolation. The separate reporting category for public street and highway lighting in the EIA-861 survey was dropped after 2000. For the years prior to 1990 and after 2000, total electricity use was extrapolated from the value from the 1990 or 2000, using the percentage change in total urban highway mileage. The final results of these interpolation and imputation adjustments are shown in Table 3.2. 
Table 3.2. Annual Estimates of Electricity Consumption for Street and Highway Lighting Based on EIA-861

\begin{tabular}{ccccl} 
Rear & $\begin{array}{c}\text { Rotal } \\
\text { Total } \\
\text { (TWh) }\end{array}$ & $\begin{array}{c}\text { Adjusted } \\
\text { Total } \\
\text { (TWh) }\end{array}$ & $\begin{array}{c}\text { Urban } \\
\text { Highway } \\
\text { Mileage } \\
\text { (Million) }\end{array}$ & Notes \\
\hline 1983 & & 13.44 & 664.2 & Extrapolated \\
1984 & & 13.72 & 677.6 & Extrapolated \\
1985 & & 13.99 & 691.0 & Extrapolated \\
1986 & & 14.25 & 704.2 & Extrapolated \\
1987 & & 14.52 & 717.4 & Extrapolated \\
1988 & & 14.79 & 730.6 & Extrapolated \\
1989 & & 15.05 & 743.8 & Extrapolated \\
1990 & 14.36 & 15.32 & 757 & ElA-861 \\
1991 & 14.53 & 15.50 & & Interpolated \\
1992 & 14.70 & 15.68 & & Interpolated \\
1993 & 14.87 & 15.86 & & Interpolated \\
1994 & 15.04 & 16.04 & & ElA-861 \\
1995 & 15.45 & 16.49 & & Interpolated \\
1996 & 15.87 & 16.93 & & ElA-861 \\
1997 & 15.35 & 16.38 & & ElA-861 \\
1998 & 15.33 & 16.35 & & ElA-861 \\
1999 & 16.18 & 17.27 & & ElA-861 \\
2000 & 17.25 & 18.40 & $\mathbf{8 5 9}$ & ElA-861 \\
2001 & & 18.94 & $\mathbf{8 8 4}$ & Extrapolated \\
2002 & & 19.33 & $\mathbf{9 0 2}$ & Extrapolated \\
2003 & & 20.44 & $\mathbf{9 5 4}$ & Extrapolated \\
2004 & & 21.30 & $\mathbf{9 9 4}$ & Extrapolated \\
2005 & & 22.37 & 1044 & Extrapolated
\end{tabular}

Notes:

1) Adjusted totals in column two are a constant 6.7 percent higher than reported totals, based on imputation model for 1997

2) Extrapolation before 1990 and after 2000 assumes proportional growth with respect to total urban highway mileage. Highway mileage values in italics are interpolated or estimated values.

The source of highway mileage is the U.S. Federal Highway Administration, originally published in Highway Statistics and summarized in the Statistical Abstract of the U.S (U.S. Census Bureau 2006).

\subsubsection{Street and Highway Lighting Electricity Use: 2002 Navigant Lighting Study}

Navigant Consulting (2002) released a comprehensive study of lighting use in the U.S. As part of the study, Navigant developed estimates of electricity consumption for street and highway lighting (termed by Navigant as "roadway" lighting). Navigant did not present all of the details of their methodology in the report, but the major elements of their methodology can be summarized as follows:

1. Annual Electricity Use per Lamp: Lawrence Berkeley National Laboratory (LBNL) provided estimates of the average wattage for street lamps, a breakdown of lamps by technology, and average operating hours.

2. Inventory of lamps used for roadway lighting: Based on 1990-2001 sales data from the National Electrical Manufacturer's Association (NEMA), Navigant developed an estimate of the stock of 
lamps (by type of high intensity discharge [HID] lamp: mercury vapor, metal halide, or high pressure sodium) for 2001. The Federal Highway Administration (FHWA), reports an estimated 60 million "cobra-head" street light fixtures were in existence in the 2000-2001 time frame. This value was used by Navigant to condition the inventory estimates derived from the NEMA sales data. $^{21}$

From these inventory and unit consumption estimates, Navigant estimated that 31 TWh of electricity was used for street and highway lighting in 2001. This value is about 64 percent higher than the estimate developed from the EIA-861 survey.

\subsubsection{Blended Results from EIA-861 and Navigant Study}

Without further study, we cannot reconcile the differing consumption estimates derived from the supply survey and the bottom-up engineering method employed by Navigant. As shown in Table 3.1, it appears that utilities reporting separate sales for street and highway lighting account for some 97 percent of all household accounts in the U.S. Thus, on its face, we do not believe that the lack of data from those utilities that do not maintain a separate rate class for this end use is a significant reason for this discrepancy. The analysis discussed in Section 3.1.1 was devoted to imputing the magnitude of this consumption for these generally smaller utilities.

Nevertheless, we concede that for some large private utilities, some sales to "other public authorities" may include electricity use for street lighting (as reported in the 861 survey prior to 2003 under this category as discussed in Section 2.1). Without contacting some major utilities to try to assess an approximate amount of electricity used for street lighting that is not billed under a specific rate schedule for that use, we have no empirical basis for developing the potential magnitude of this consumption.

Unfortunately, it is difficult to devise a straightforward methodology to validate the bottom-up engineering estimate developed by Navigant. If an inventory of street lamps could be developed for a particular utility, then the engineering methodology could be calibrated to the reported consumption. Unfortunately, the inventory of lamps can be developed only at the national level because only national sales data are readily available.

At this point, our approach is to blend these two estimates in an effort to come up with what is hoped will be a more accurate estimate than either of the estimates alone. Our supposition at this point is that the actual consumption probably lies closer to the EIA-861-derived estimate than the Navigant estimate. The supply survey estimate is based on reported consumption and, thus, is much less dependent on a number of assumed parameters underlying the Navigant approach. Under this reasoning, the 2001 estimate for this study will be based on a weighted average of the EIA-861 value and Navigant estimate, with the weights chosen as 0.7 and 0.3 , respectively. With these weights, the blended estimate for 2001 is about 19 percent higher than the estimate based on the EIA survey. A constant 19 percent adjustment factor is used to develop the blended estimates for the entire time period; the results are shown in Table 3.3.

\footnotetext{
${ }^{21}$ No specific details were provided by Navigant as to how these various data sources were combined. In the words of the report, "Working between the LBNL estimates, an approximation of the installed base of HID lamps from NEMA's decade of sales and the FHWA estimate of 60 million fixtures, an estimate of the installed base was generated" (Navigant 2002, p. 28)
} 
Table 3.3. Estimates of Street and Highway Electricity Based on Blended Estimates from the EIA-Survey and the 2002 Navigant Lighting Study

Estimate

Based on Navigant Blended

EIA-861 Estimate Estimate

\begin{tabular}{cccc} 
& (TWh) & (TWh) & (TWh) \\
\hline 1983 & 13.44 & & 16.01 \\
1984 & 13.72 & & 16.33 \\
1985 & 13.99 & & 16.66 \\
1986 & 14.25 & & 16.98 \\
1987 & 14.52 & & 17.29 \\
1988 & 14.79 & & 17.61 \\
1989 & 15.05 & & 17.93 \\
1990 & 15.32 & & 18.25 \\
1991 & 15.50 & & 18.46 \\
1992 & 15.68 & & 18.68 \\
1993 & 15.86 & & 18.89 \\
1994 & 16.04 & & 19.11 \\
1995 & 16.49 & & 19.64 \\
1996 & 16.93 & & 20.17 \\
1997 & 16.38 & & 19.51 \\
1998 & 16.35 & & 19.48 \\
1999 & 17.27 & & 20.56 \\
2000 & 18.40 & & 21.92 \\
2001 & 18.94 & 31 & 22.56 \\
2002 & 19.33 & & 23.02 \\
2003 & 20.44 & & 24.34 \\
2004 & 21.30 & & 25.37 \\
2005 & 22.37 & & 26.64
\end{tabular}

\subsection{Parking Lot Lighting}

Drive through any suburban shopping area at night and one sees large expanses of paved parking areas brightly lit. Lighting of outdoor parking lots is a major commercial use of electricity.

Unfortunately, there are no comprehensive or consistent data sets that allow one to develop a rigorous estimate of lighting electricity consumption for outdoor parking. Several issues must be addressed. First, the national estimates of the number of parking spaces (off-street) appear to be only very approximate. Second, the variation of the illumination levels - and corresponding electricity use--for various types of parking areas is large. Finally, an unknown amount of electricity for parking areas may be included in the CBECS as many parking lot lighting fixtures are connected to a building's master electrical panel.

Several sources were used to develop estimates of parking lot electricity use over time. The first is the 2002 Navigant study on U.S. lighting consumption. That study provides a framework for estimating national electricity use for parking. A second source is a set of publications related to a 2003 study of outdoor lighting use in California. 


\subsubsection{Navigant Lighting Inventory Study}

The 2002 lighting characterization study by Navigant Consulting addressed a number of outdoor lighting uses including parking (Navigant Consulting 2002). In developing a national estimate of parking lighting, Navigant uses a straightforward approach:

Lighting use $=($ Number of parking spaces $) \times($ Square feet/parking space $) \times$

(Watts/square foot $) \times($ Operating hours per year $)$

The number of national (off-street) parking spaces is taken from estimates from the International Parking Institute (IPI), As cited by Navigant, the IPI estimated that there were some 70.5 million off-street parking spaces in the U.S. Navigant contacted Walker Parking consultants who suggested that the average size per parking space is 300 square feet with an average of 0.2 watts per square foot of parking area. From a 1999 LBNL study cited by Navigant, the average utilization of parking lighting is 10 hours. When all of these values are employed in the above multiplicative expression, the estimated total national electricity use for parking is $16.9 \mathrm{TWh}$.

Inexplicably, however, the estimates of electricity consumption for parking lighting in the final results tables in the Navigant report are inconsistent with this estimate. Total lighting for parking in their final summary table is over $30 \mathrm{TWh}^{22}$ Thus, for this study, we have taken another look at each of the factors in the multiplicative expression (Eq. 3.2) to develop a revised estimate based on this top-down approach.

\section{Number of Parking Spaces}

An internet search suggests that IPI is the only organization that has attempted to develop a national estimate of parking spaces in the U.S. Unfortunately, but understandably, the estimate can be viewed as only approximate and it is not clear as to the particular time period to which it applies. The 2002 Navigant study cites a 2000 reference from IPI for the estimate of 70.5 million off-street parking spaces. However, IPI's current website continues to show this number, so it is clear that this estimate is not based on a periodic survey estimates. ${ }^{23}$ For purposes of this study, we will assume that the estimate of 70.5 million spaces applies to 2001. As in the Navigant study, we also assume all of these spaces are lighted.

Some fraction of off-street parking is in parking garages and other structures. Based on the discussion of parking garages in Section 1, the number of parking spaces in dedicated parking garages in 2001 is

\footnotetext{
${ }^{22}$ Navigant attempted to disaggregate electricity used for parking that is included with building electricity (as collected in large sample of audited commercial buildings) and other electricity use used solely for parking lighting. As input to their final estimate, Navigant came up with an estimated 22 million outdoor lighting fixtures with an average 270 watts per fixture (for parking lot usage not included with the building's electrical bill). If Navigant had used the estimate of total parking spaces at 70.5 million, the 22 million fixtures would imply one fixture for just over three parking spaces. Casual observation of typical parking lots would suggest that this fixture density is much too high.

${ }^{23}$ On IPI's FAQ (Frequently Asked Questions) webpage, the following short paragraph summarizes the institute's estimate of the number of parking spaces: "The International Parking Institute estimates that there are 105,200,000 parking spaces in the U.S., a number that changes every day. The ratio of off-street spaces to on-street is roughly two-to-one." The IPI web address is http://www.parking.org/Value/FAQ/Default.aspx.
} 
estimated to be 6.9 million. We have not tried to develop an estimate for parking spaces in other structures (e.g., below-grade parking areas in large office buildings). For purpose of estimating electricity use for outdoor parking, we end up with an estimate of about 64 million spaces for 2001 (70.5 million 6.9 million).

Given the uncertainty about the current number of off-street parking spaces, it is no surprise that sources for prior years are not available. Several means of scaling the parking space estimate for 2001 to earlier (and later) years were considered, including population, number of registered vehicles, and building floor space. Typically, however, the number of parking spaces can be thought to be roughly related to the associated building floor space. Because local building codes and building design practices that cover the parking requirements for new buildings are viewed to change slowly over time, for this study we have scaled the parking space estimates to other years by total commercial floor space.

In concluding this subsection, our intuition suggests that IPI may be underestimating the total number of off-street spaces. The 2000 Census indicated that some 90 million workers drive alone to work. Assuming that nearly all of these workers park in off-street spaces, then the number of spaces would equal the number of workers. Two major adjustments might be applied for purposes of estimated parking associated with the commercial sector. First, there are approximately 20 million workers in manufacturing, mining, and construction jobs. Second, some parking spaces would be shared by workers in shift jobs. However, even with these adjustments, one might surmise that the additional number of spaces related to non-work destinations (retail, health care, schools, airports, etc.) would be sufficient to make the total number of parking spaces higher than the 70 million estimated by IPI. However, without knowledge of the IPI methodology or a detailed effort to develop an alternative methodology, this study will rely on the IPI estimate.

\section{Square Feet per Parking Space}

The 2002 Navigant study cites Walker Parking Consultants for an estimated average of 300 square feet per parking space. Recent work by LBNL in a report prepared for the California Energy Commission (Architectural Energy Corporation 2003) suggests a range of 250-500 square feet (including landscaping for surface lots). As discussed in Section 2 above, the average size for parking spaces in five parking garages at the University of Virginia was 350 square feet. Based on these latter two data points and given that lighting is used for entrance and exit roadways, we have chosen to use a value of 350 square feet per parking space (16 percent higher than that cited in the Navigant study).

\section{Watts per Square Foot of Outdoor Parking}

While the Navigant study suggested lighting power density (LPD) of 0.2 watts per square foot for outdoor parking, more recent studies suggest a much lower value. The outdoor lighting study conducted for the CEC in 2002 indicated an average of 0.08 watts per square foot for California (CEC 2003). Given somewhat higher electricity prices in California and likely more focus on lighting conservation in that state, we have chosen to use a slightly higher estimate of 0.10 watts/sq. ft. for a national average. ${ }^{24}$

\footnotetext{
${ }^{24}$ The figure of 0.1 watts/sq. ft. or lower was also supported by a discussion with Don Monahan of Walker Parking Consultants (personal communication, Nov. 1, 2006). ASHRAE Standard 90.1-2004 requires the LPD for outdoor lighting to be less than or equal to 0.15 watts/sq. ft., which provides some rationale that the national average LPD is probably higher than in California.
} 


\section{Annual Operating Hours}

The 2002 Navigant lighting characterization employed a value of 3650 hours per year (10 hours per day) in the development of its lighting electricity estimates. That figure is adopted for our estimation methodology in this report.

\section{Estimates of National Outdoor Parking Lighting Electricity Use}

The first three columns of Table 3.4 display the results of these input assumptions. As shown in bold for 2001, the estimate of outdoor lighting for off-street (surface) parking is 8.2 TWh.

Table 3.4. Estimates of Parking Lot Lighting

\begin{tabular}{|c|c|c|c|c|}
\hline Year & $\begin{array}{l}\text { Number of } \\
\text { Off-street } \\
\text { Spaces } \\
\text { (million) }\end{array}$ & $\begin{array}{l}\text { Total Parking } \\
\text { Area (bil. SF) } \\
\text { (billion sq. ft.) }\end{array}$ & $\begin{array}{l}\text { Total } \\
\text { Electricity } \\
\text { Use } \\
\text { (TWh) }\end{array}$ & $\begin{array}{l}\text { Electricity } \\
\text { Not in } \\
\text { CBECS } \\
\text { (TWh) }\end{array}$ \\
\hline 1983 & 47.0 & 16.4 & 6.00 & 3.00 \\
\hline 1984 & 47.9 & 16.8 & 6.12 & 3.06 \\
\hline 1985 & 49.0 & 17.2 & 6.26 & 3.13 \\
\hline 1986 & 50.1 & 17.5 & 6.40 & 3.20 \\
\hline 1987 & 51.1 & 17.9 & 6.53 & 3.27 \\
\hline 1988 & 52.1 & 18.2 & 6.66 & 3.33 \\
\hline 1989 & 53.1 & 18.6 & 6.78 & 3.39 \\
\hline 1990 & 53.8 & 18.8 & 6.88 & 3.44 \\
\hline 1991 & 54.4 & 19.0 & 6.95 & 3.47 \\
\hline 1992 & 54.9 & 19.2 & 7.01 & 3.50 \\
\hline 1993 & 55.4 & 19.4 & 7.07 & 3.54 \\
\hline 1994 & 56.0 & 19.6 & 7.16 & 3.58 \\
\hline 1995 & 56.8 & 19.9 & 7.25 & 3.63 \\
\hline 1996 & 57.5 & 20.1 & 7.35 & 3.67 \\
\hline 1997 & 58.5 & 20.5 & 7.47 & 3.74 \\
\hline 1998 & 59.7 & 20.9 & 7.63 & 3.82 \\
\hline 1999 & 61.0 & 21.4 & 7.80 & 3.90 \\
\hline 2000 & 62.4 & 21.8 & 7.97 & 3.99 \\
\hline 2001 & 63.6 & 22.2 & 8.12 & 4.06 \\
\hline 2002 & 64.5 & 22.6 & 8.24 & 4.12 \\
\hline 2003 & 65.4 & 22.9 & 8.36 & 4.18 \\
\hline 2004 & 66.3 & 23.2 & 8.47 & 4.24 \\
\hline 2005 & 67.3 & 23.6 & 8.60 & 4.30 \\
\hline
\end{tabular}

Notes:

1) Number of off-street spaces is for surface lots only, see text. Estimates for years other than 2001 developed by scaling the 2001 value by total commercial floor space.

2) Total parking area based on 350 sq. ft. per parking space

3) Total electricity use based on 0.1 watts per square foot and 3650 operating hours per year

4) Fifty percent of total use assumed to not be included in CBECS

Thus far, the development of the electricity use for outdoor lighting has been conducted solely on a quasiengineering basis. Of relevance for this study, however, is how much of this electricity use is not included 
in the CBECS, but is reported by utilities as commercial sales. Unfortunately, we have little information by which to make an apportionment.

The electricity consumption estimate for a specific building in the CBECS is based on electricity bills supplied by the relevant utility, or in the more recent CBECS, by bills supplied by the building respondent. In some cases, separate bills (based on separate meters) for outdoor lighting (and signage) may be submitted to EIA as part of the CBECS, but EIA attempts to exclude the electricity use from these bills in their estimate of overall building consumption. One large category for which multiple bills may be submitted is for retail strip and large shopping malls. Usually, the outdoor lighting (and signage) is separately metered and billed to the overall property owner or manager. This may also be thought to occur in suburban office parks consisting of multiple buildings. For small buildings, and buildings with a single owner and use (e.g., a church or restaurant), the parking lights may be connected to the building's master electrical panel, with the result that the outdoor lighting use is included along with all of the building's other end uses.

Commercial off-street surface parking lots are also not included in the CBECS, but the electricity use associated with these facilities would be reported by utilities as commercial sales. At one point during the study, it was hoped that this might be the dominant use of outdoor lighting not included in the CBECS, but consideration of shopping malls and other large building complexes suggests that this is not the case.

As we have no clear notion of whether the majority of outdoor lighting falls within the CBECS reporting framework, and that even a partial resolution of the question would involve a survey effort, we have chosen to assume that 50 percent of the estimated total electricity use for parking lighting is not included in the CBECS. The estimates based on this assumption are shown in the last column of Table 3.4.

\subsubsection{CEC Assessment of Outdoor Lighting in California}

In a comprehensive study of outdoor lighting in California funded by the California Energy Commission during 2001 and 2003, electricity consumption estimates for a number of outdoor lighting end uses were developed (CEC 2003). The CEC relied on a sample of 300 commercial sites within the state for which lighting data were collected for nearly 800 functional use categories (e.g., parking, walkways, security areas, etc.). The final results for the study are reproduced in Table 3.5.

The California results for outdoor parking lighting provide some corroboration to the national estimates developed in the previous section. If we assume that electricity used for parking lighting is roughly proportional to the number of registered vehicles, we have a simple means to extrapolate the California consumption estimates to the nation. In 2001, California accounted for 12.4 percent of the nation's registered vehicles (U.S. Census Bureau 2003). Dividing the California consumption estimate by 0.124 yields a national estimate of 7.7 TWh, very close to the 2001 value of $8.3 \mathrm{TWh}$ shown in Table 3.4.

As part of an evaluation of the draft CEC baseline assessment study, LBNL (CEC 2003a) provided a validity check of the electricity used for outdoor parking. Beginning with the overall electricity use estimate, and assumed averages for square footage per parking space (360 sq. ft./space), and annual consumption per square foot, they backed out an estimate of approximately 7.7 million parking spaces. LBNL concluded that this result was a "reasonable value." If we extrapolate this estimate to the nation on 
the basis of registered vehicles, we end up with 61.7 million (off-street, surface) parking spaces. This value is not far from the 2001 U.S. estimate of 63.6 million shown in Table $3.4 .^{25}$

Table 3.5. Estimates of Outdoor Lighting Use in California

\begin{tabular}{|l|c|}
\hline Function Use Area & Energy Use (GWh) \\
\hline Parking & 967.3 \\
\hline Pedestrian and Walkway & 685.6 \\
\hline Signage & 622.6 \\
\hline Security & 207.9 \\
\hline Storage & 159.5 \\
\hline Outdoor Retail Sales & 140.2 \\
\hline Internal Roadway & 74.4 \\
\hline Recreation & 47.6 \\
\hline Façade and Aesthetic & 43.5 \\
\hline Entry & 40.0 \\
\hline Landscape & 39.9 \\
\hline Gas Station Canopy & 29.8 \\
\hline Automated Teller Machine & 6.8 \\
\hline Undeveloped & 1.9 \\
\hline Commercial Outdoor Patio & 0.5 \\
\hline Total Energy Usage & $\mathbf{3 0 6 7}$ \\
\hline
\end{tabular}

Source: California Outdoor Lighting Assessment (CEC 2003)

\subsection{Other Outdoor Lighting}

\subsubsection{Traffic Signals}

In late 2003, Navigant Consulting published a comprehensive report that examined the use of light emitting diode (LED) lighting devices in various applications (Navigant 2003). One of the major applications for LEDs over the past decade has been their use in traffic signals. The Navigant study estimated both the total amount of energy used in traffic signals in the U.S. in 2002 and the electricity savings (as compared to incandescent) that could be attributed to the adoption of LEDs.

Based on discussions with industry experts, the Navigant study estimated that approximately 30 percent of traffic signals had been converted to LEDs by 2002. Based on more recent discussion with one of these industry contacts, the 30 percent market penetration shown in the Navigant report is more likely to have been reached in 2003, rather than 2002. ${ }^{26}$ The changeover from incandescent to LEDs has been very rapid in the subsequent three years. By 2006, the overall market penetration is estimated to be approximately 60 percent. ${ }^{24}$.

\footnotetext{
${ }^{25}$ With regard to the speculation at the end of Section 3.2.1 that the number of off-street parking spaces may significantly exceed the IPI estimate, it appears that a reasonable assumption is that the approximately 60 million spaces are lighted on average in the manner assumed in the study. Any approach that might suggest a higher number of outdoor parking spaces would have to conclude that many of these spaces have minimal lighting.

${ }^{26}$ Personal communication with Gary Durgin of Dialight, Farmingdale, New Jersey, January 2007.
} 
Table 3.6 seeks to blend this more recent information with that published by Navigant (2003). The Navigant study estimated that traffic signals used 3.41 TWh in 2002, with 1.48 TWh of electricity savings accounted for by LEDs. Thus, we conclude that without the use of LEDs, all traffic signals would have consumed 4.89 TWh of electricity in 2002. This value is shown in bold in the second column of Table 3.6. If we assume that the number of traffic signals - and concomitant electricity use - over time is roughly proportional to total urban road mileage (column one in the table), then we can generate an historical series of hypothetical electricity usage under the assumption that only incandescent lamps were used in the signals. That series is shown in the second column of the table.

Based on a revised market penetration estimate for 2002, the associated electricity savings in that year are reduced from $1.48 \mathrm{TWh}$ to $1.06 \mathrm{TWh}$. This level of savings is subsequently scaled in proportion to the

Table 3.6. Historical Estimates of Electricity Consumption for Traffic Signals

\begin{tabular}{cccccc}
\multicolumn{7}{c}{$\begin{array}{c}\text { Urban } \\
\text { Road } \\
\text { Mileage } \\
\text { (mill. } \\
\text { Miles) }\end{array}$} & $\begin{array}{c}\text { Electricity Use } \\
\text { - Traffic } \\
\text { Signals (All } \\
\text { Incandescent) } \\
\text { (TWh) }\end{array}$ & $\begin{array}{c}\text { Estimated } \\
\text { Market } \\
\text { Share - } \\
\text { LED }\end{array}$ & $\begin{array}{c}\text { Savings } \\
\text { from LED } \\
\text { Lamps } \\
\text { (TWh) }\end{array}$ & $\begin{array}{c}\text { Electricity Use - } \\
\text { Traffic Signals } \\
\text { (Incandescent+ } \\
\text { LED) (TWh) }\end{array}$ \\
\hline 1980 & $\mathbf{6 2 4}$ & 3.45 & & & 3.45 \\
1981 & 637.4 & 3.53 & & & 3.53 \\
1982 & 650.8 & 3.60 & & & 3.60 \\
1983 & 664.2 & 3.67 & & & 3.67 \\
1984 & 677.6 & 3.75 & & & 3.75 \\
1985 & 691 & 3.82 & & & 3.82 \\
1986 & 704.2 & 3.90 & & & 3.90 \\
1987 & 717.4 & 3.97 & & & 3.97 \\
1988 & 730.6 & 4.04 & & & 4.04 \\
1989 & 743.8 & 4.11 & & & 4.11 \\
1990 & 757 & 4.19 & & & 4.19 \\
1991 & 769.4 & 4.26 & & & 4.26 \\
1992 & 781.8 & 4.32 & & & 4.32 \\
1993 & 794.2 & 4.39 & & & 4.39 \\
1994 & 806.6 & 4.46 & & & 4.46 \\
1995 & $\mathbf{8 1 9}$ & 4.53 & & & 4.53 \\
1996 & 827.0 & 4.57 & $0.2 \%$ & 0.01 & 4.57 \\
1997 & 835.0 & 4.62 & $1 \%$ & 0.04 & 4.58 \\
1998 & 843.0 & 4.66 & $2 \%$ & 0.09 & 4.58 \\
1999 & 851.0 & 4.71 & $3 \%$ & 0.16 & 4.54 \\
2000 & $\mathbf{8 5 9}$ & 4.75 & $6 \%$ & 0.29 & 4.46 \\
2001 & $\mathbf{8 8 4}$ & 4.89 & $14 \%$ & 0.67 & 4.22 \\
2002 & 902 & 4.89 & $22 \%$ & 1.06 & 3.83 \\
2003 & 954 & 5.28 & $31 \%$ & 1.48 & 3.80 \\
2004 & 994 & 5.50 & $41 \%$ & 1.97 & 3.53 \\
2005 & 1044.0 & 5.78 & $51 \%$ & 2.46 & 3.31 \\
& & & & &
\end{tabular}

Notes:

1) Highway Mileage from U.S. Census Bureau 2006. Figures in italics based on interpolated or extrapolated values

2) 2002 Estimate for Electricity Use from Navigant 2003, see text discussion. Values for other years extrapolated from mileage values. 
estimated market penetrations shown in column three of the table. The market penetrations are based, in part, on proprietary estimates of LED signal sales for selected years (Durgin, personal communication), with interpolated values for the other years. The last column in Table 3.6 shows the resulting estimates of lighting electricity use in traffic signals after accounting for the estimated LED savings. The estimates are derived by subtracting the LED savings from the values in column two of the table.

\subsubsection{Billboard and Airport Lighting}

In Navigant's 2002 overall study of U.S. lighting, billboard and airport runway lighting were also considered. The total electricity use for these uses was estimated to be $1 \mathrm{TWh}$ in 2001. As this small magnitude would not materially affect any conclusions from this study, these end uses have been ignored.

\subsubsection{Walkway and Pedestrian Lighting}

The 2003 CEC study of outdoor lighting in California was restricted to outdoor lighting associated with commercial uses (in the context of "commercial" buildings, thus excluding public roadways, traffic signals, and airports). Going back to Table 3.5, one finds that while electricity use for parking is the largest end use of outdoor lighting, it still only contributes about a third of total lighting use considered in the study. We would not expect these results to be markedly different for other states. The next two largest end uses are walkway and pedestrian lighting and signage. We assume that most of the walkway and pedestrian lighting would be associated with areas in close proximity to a building and thus be metered along with the rest of the building (and, as result, be included in the CBECS). For signage we speculate that, as compared to walkways and pedestrian lighting, a greater fraction of electricity use would be excluded from the CBECS (e.g., signage on the perimeters of shopping centers). However, we have no reasonable method to make any apportionment and so have ignored its inclusion in the categories of electricity use reported by the supply surveys (EIA-861) but not by CBECS.

\subsection{Water Supply and Treatment}

Public utilities supply more than 40 billion gallons of water per day to people living in U.S. towns and cities; all of this water must be pumped from underground wells or surface bodies of water. In addition to water distribution, fresh water must be treated before it can be safely used by households and businesses. Much of this water as well as runoff from rain and snow must also be treated before it is released back into the environment. All of these activities require a large amount of electricity for pumping and treatment operations.

The electricity used for water supply and treatment for domestic consumers (i.e., excluding industrial and agricultural uses) is classified as commercial consumption. Clearly, the facilities that undertake these operations are not included in the CBECS. Accordingly, we seek some means of estimating the electricity used in these facilities.

Fortunately, EPRI was interested in just this question a few years ago. In 2002, EPRI issued a series of reports on water and sustainability that included estimates of amount of electricity used for water supply and treatment in the U.S. More recently, EIA tasked the TIAX Consulting group to look at miscellaneous electricity consumption in the residential and commercial sectors. Among the topics considered by TIAX was water supply and treatment. While relying primarily on the EPRI report, TIAX made a minor extension (and update) to the EPRI work.(EPRI 2002; TIAX 2006) The following two sections summarize some of the key findings from both of these reports and show how historical estimates have been developed for this study. 


\subsubsection{EPRI Report Related to Water and Sustainability}

Perhaps the only comprehensive set of estimates for electricity consumption for these uses was published by EPRI (2002). Volume 4 is the last in a series of reports on water and sustainability that developed estimates of electricity consumption and projection for various aspects of water supply and treatment. The report made separate estimates of electricity consumption for surface water and groundwater supply of fresh water and for wastewater treatment.

\section{Fresh Water Supply}

For public supply from surface water, the EPRI report derived an estimate of $1406 \mathrm{kWh}$ per million gallons as typical for a plant with a capacity of 10 million gallons per day. The report estimated that between 80 and 85 percent of that electricity is used to pump treated water into the distribution system; the remainder is for various steps in purification processes. For groundwater, the total pumping requirements are greater as water must be pumped from wells of various depths. However, the electricity needed to treat groundwater is much lower than for surface water.

Using a defined set of unit electricity consumption requirements along with a 1999 inventory of public water supply systems conducted by the Environmental Protection Agency (EPA), EPRI derived estimates of total U.S. electricity consumption for fresh water supply by public agencies. For the year 2000, this methodology yielded an estimate of just over 30 billion $\mathrm{kWh}(30.5 \mathrm{TWh})$.

\section{Wastewater Treatment}

Because the variation in the types of wastewater treatment is very large, the estimation of unit energy consumption is difficult. To simplify its analysis, the 2002 EPRI report examined four representative types of treatment facilities:

- trickling filter

- activated sludge

- advanced wastewater treatment

- advanced wastewater treatment with nitrification.

For each of these major types of treatment processes, the authors of the EPRI report developed estimates of unit energy (electricity) consumption (per gallon of wastewater treated). The unit consumption estimates were aggregated over ranges of capacities to yield a single value for national use projections. The unit electricity consumption estimates ranged from $955 \mathrm{kWh} /$ million gallons for trickling filter systems to $1911 \mathrm{kWh} /$ million gallons for advanced wastewater treatment with nitrification.

Similar to the approach used for fresh water supply, a national estimate of total electricity consumption was based on the unit consumption values and information derived from an inventory of publicly owned water treatment facilities. As for water supply systems, this inventory was conducted by EPA and forms the basis for the Clean Water Needs Survey, reported on a regular basis to Congress. The EPRI report made use of the inventory data reported in 1996. Based on this information, EPRI developed an estimate of just over $21 \mathrm{TWh}$ for all publicly-owned wastewater facilities in the U.S. 


\section{Historical Trends}

The 2002 EPRI report focused on developing current ("snapshot") estimates of electricity use for water supply and treatment as well as projected electricity use through 2050. Accordingly, the only historical data point in the report is for the base year of 2000.

For projecting future unit energy use for the fresh water supply, the authors of the report suggest that there are factors that work in both directions to influence total energy use. The following factors tend to increase unit electricity consumption:

- The age of the delivery system: electricity for pumping increases as friction in piping increases over time.

- Implementation of water restrictions: while total electricity use may decline, some economies of scale would be lost and unit consumption requirements may increase.

- Requirements for improved treatment: More rigorous treatment leads to higher electricity use.

Alternatively, unit electricity consumption would decline from the following factors:

- Economies of scale: a trend to larger systems will require less electricity per gallon of water supplied.

- Newer equipment: Newer equipment—pumps, drives and water processing equipment—-tends to be more energy efficient.

The United States has more than 150,000 public water supply systems; the authors of the EPRI report suggest that few are likely to operate identically. Thus, it is difficult to predict how these factors would combine to either increase or decrease unit energy requirements in the future. By extension for the present analysis, the same issue is relevant to how unit electricity consumption may have changed in the recent past (decade or two). For the purpose of the developing the projections of future electricity use, the authors write, "For the purpose of this exercise, it is probably adequate to note that unit electricity consumption will most likely remain close to present to presents levels or increase slightly of the next 20 years."

Taking this same approach for "backcasting" the 2000 consumption to earlier years, we assume that a reasonable assumption is to (implicitly) hold unit energy consumption at its 2000 value. If we further assume that water use per capita has remained constant over the same period, the value of current consumption can be extrapolated (backward) solely on the basis of population change.

The development of historical estimates of electricity use for wastewater treatment is not quite as straightforward as for fresh water supply. The 2002 EPRI report suggests that the stringency of treatment has been increasing over time; thus a careful approach should take this trend into account.

As for fresh water supply, EPRI suggests factors that can either increase or decrease unit energy requirements for wastewater treatment. In general, the same considerations apply to wastewater treatment: 1) age of the treatment system (increased electricity use), 2) increased requirements for treatment (higher electricity use), 3) trend toward larger system with greater economies of scale (lower electricity use), and 4) replacement by newer equipment (lower electricity use).

In the view of the authors of the EPRI report, the principal factor is believed to be the degree of treatment required that, on balance, has increased unit electricity requirements over time. Based on a comparison of 
estimated unit electricity consumption in 1988 to that estimated for 2000, the report concludes that "the baseline unit energy consumption was estimated to increase at an average compound rate of about 0.8 percent per year." ${ }^{27}$ Using this estimate of the trend rate of increase in unit electricity requirements and an assumption that wastewater volumes per capita has remained constant provides a reasonable approach to backcast the value of current electricity consumption for wastewater treatment.

A report prepared by TIAX Consulting for EIA (TIAX 2006) has slightly extended and updated the EPRI estimates. The next section describes how this more recent report was used to develop historical estimates of electricity use for water supply and treatment.

\subsubsection{TIAX Report on Miscellaneous Commercial Electricity Uses}

A more recent look at electricity use for water supply and treatment has been taken by TIAX in a report prepared for EIA (TIAX 2006) ${ }^{28}$. In large part, TIAX used the unit electricity estimates developed in the 2002 EPRI report. However, TIAX both updated and expanded on the EPRI work in several areas:

- Update to 2005: TIAX updated the base year consumption to 2005. It appears in some cases that TIAX used more recent information related to the quantity of fresh water supplied and wastewater treated.

- Explicit estimate for water purification: The TIAX report develops a separate electricity estimate for water purification from the electricity used for water distribution.

- Inclusion of large-scale water transfer projects: TIAX develops estimates of the electricity used for three inter-basin water transfer projects: the California State Water Project, the Central Arizona Project, and Colorado River Aqueduct. TIAX estimated that these projects account for about 20 percent of U.S. water pumping energy consumption, estimated to be $8 \mathrm{TWh}$.

\subsubsection{Historical Estimates}

Table 3.7 shows estimates of annual electricity consumption based on the EPRI and TIAX reports. The 2005 estimates are taken from the TIAX report and projected backwards based on the discussion in Section 3.4.1. For water pumping, we assumed no change in unit electricity consumption; thus, the 2005 estimate is scaled proportionately to earlier years on the basis of population. The estimates for earlier years for water treatment are based on both population growth and an assumed 0.8 percent annual growth

\footnotetext{
${ }^{27}$ An explicit derivation of this trend rate of change is not presented in the report. Based on unit energy consumption for various treatment methods and the distribution of these methods for 1988 and 1996, we compute an average rate of change of about 0.55 percent per year. The authors of the EPRI must assume some increases in the unit electricity consumption within each of the treatment categories or are employing other information not explicitly cited in the report.

${ }^{28}$ The TIAX report develops estimates for number of miscellaneous end uses classified in the commercial sector (e.g., bank teller machines, service station equipment, and medical equipment.) Water supply and treatment involves the largest use of electricity not contained within a building.
} 
in unit energy requirements. ${ }^{29}$ For water purification, the annual rate of increase in unit electricity consumption was set at 0.4 percent, half of the value assumed for water treatment.

For water pumping (water distribution in public water systems), the estimates in Table 3.7 include the electricity used in the large-scale water transfer systems (i.e., the three major projects cited in the third bulleted item above). ${ }^{30}$ The TIAX report suggests that about 8 TWh were used in these projects in 2005 . While the amount of electricity used in these projects varies from year to year depending upon water supply conditions, we believe that the trend increase in consumption since the early 1980s has likely been flat or very small. These projects have been essentially complete for the past several decades. Thus, in the development of the historical estimates, a constant $8 \mathrm{TWh}$ has been assumed for all years for this component of water pumping electricity use.

${ }^{29}$ As explained in the subsequent paragraph, about $20 \%$ or 8 TWh of the 2005 total of 40 TWh is estimated by TIAX to relate to three large water projects in the West. This component of electricity use was not scaled by population.

${ }^{30}$ The electricity use for these water transfer systems is assumed to be ultimately classified by EIA as commercial sales. The electricity use for the Central Arizona Project is purchased from Arizona Public Service under commercial rates. Much of the electricity used for Colorado River Aqueduct is supplied by the Hoover and Parker dams on the Colorado River and presumably shows up as "other sales to public authorities" (See Table 2.1). A portion of the electricity used by the California State Water Project is supplied by investor-owned utilities in California as well as dams in northern California. 
Table 3.7. Annual Estimates of Electricity Use for Water Supply and Treatment

\begin{tabular}{cccccc} 
Year & $\begin{array}{c}\text { Resident } \\
\text { Population } \\
\text { (millions) }\end{array}$ & $\begin{array}{c}\text { Water } \\
\text { Pumping } \\
\text { (TWh) }\end{array}$ & $\begin{array}{c}\text { Fresh } \\
\text { Water } \\
\text { Treatment } \\
\text { (TWh) }\end{array}$ & $\begin{array}{c}\text { Wastewater } \\
\text { Treatment } \\
\text { (TWh) }\end{array}$ & $\begin{array}{c}\text { Total } \\
\text { (TWh) }\end{array}$ \\
\hline 1983 & 233.8 & 33.2 & 0.8 & 16.2 & 50.2 \\
1984 & 235.8 & 33.4 & 0.8 & 16.5 & 50.7 \\
1985 & 237.9 & 33.7 & 0.8 & 16.7 & 51.2 \\
1986 & 240.1 & 33.9 & 0.8 & 17.0 & 51.8 \\
1987 & 242.3 & 34.1 & 0.8 & 17.3 & 52.3 \\
1988 & 244.5 & 34.4 & 0.8 & 17.6 & 52.8 \\
1989 & 246.8 & 34.6 & 0.9 & 17.9 & 53.4 \\
1990 & 249.6 & 34.9 & 0.9 & 18.3 & 54.1 \\
1991 & 253.0 & 35.3 & 0.9 & 18.7 & 54.9 \\
1992 & 256.5 & 35.7 & 0.9 & 19.1 & 55.7 \\
1993 & 259.9 & 36.0 & 0.9 & 19.5 & 56.4 \\
1994 & 263.1 & 36.4 & 0.9 & 19.9 & 57.2 \\
1995 & 266.3 & 36.7 & 0.9 & 20.3 & 58.0 \\
1996 & 269.3 & 37.1 & 1.0 & 20.7 & 58.7 \\
1997 & 272.6 & 37.4 & 1.0 & 21.1 & 59.5 \\
1998 & 275.9 & 37.8 & 1.0 & 21.5 & 60.3 \\
1999 & 279.0 & 38.1 & 1.0 & 22.0 & 61.1 \\
2000 & 282.2 & 38.4 & 1.0 & 22.4 & 61.9 \\
2001 & 285.1 & 38.8 & 1.0 & 22.8 & 62.6 \\
2002 & 287.9 & 39.1 & 1.1 & 23.2 & 63.3 \\
2003 & 290.9 & 39.4 & 1.1 & 23.6 & 64.1 \\
2004 & 293.7 & 39.7 & 1.1 & 24.1 & 64.8 \\
2005 & 296.6 & 40.0 & 1.1 & 24.5 & 65.6
\end{tabular}

\subsection{Cell Phone Sites (Towers)}

The growth of cell phone industry by any measure has been phenomenal over the past decade. Americans now use nearly 200 million cell phones.

Satisfactory cell phone service requires cell towers and antennas to be located in sufficient numbers to handle the volume of calls without undue delays. As cell phone use continues to grow, companies must find new places to keep up with demand.

A natural question is what impact the growth of the cell phone industry has had on commercial sector electricity sales since 1990. A very rough estimate is developed below by multiplying the number of cell phone sites times an average annual electricity use per site.

The Cellular Telecommunications and Internet Association (CTIA) is the trade group for the cell phone industry. According to an Associated Press story in the summer of 2005, the number of cell sites - mostly towers and antennas - have increased from fewer than 18,000 in 1994 to more than 175,000 now (Wired 
2005). As CTIA collects and publishes this data together on an annual basis, the timing of "now" is assumed to refer to the most recent year-2004. ${ }^{31}$

The average electricity usage per cell tower is more problematic. References to cell phone tower electricity use were found that ranged from 16 watts to as high as 5000 watts. As one example, a 2004 article (Barton 2004) quotes a Cingular Wireless planning consultant suggesting that "an average cellphone tower . . emits a about 400 watts." Antenna losses may be as great as emitted power, so power usage for these sites could be in the range of 1000 watts.

An older, but more comprehensive, source is the 2001 study by Arthur D. Little (ADL) for DOE's Office of Building Technology State and Community Programs. In the ADL study, cell sites were divided into three separate categories: macro, mini, and micro/pico. Based largely on its discussions with several industry consultants (S. Blazewisz, J. Plateburg), ADL assigned average power draw requirements and the percentage of total sites corresponding to these categories. These estimates are shown in Table 3.8. Based on these estimates, the average consumption per cell site was calculated by ADL to be 2650 watts.

Table 3.8. Average Power Consumption and Distribution by Type of Cell Site

\begin{tabular}{|l|c|c|}
\hline Cell Type & $\begin{array}{c}\text { Average Power } \\
\text { Draw, Watts }\end{array}$ & $\begin{array}{c}\text { Percent of } \\
\text { Total Sites }\end{array}$ \\
\hline Macro & 5000 & $30 \%$ \\
\hline Mini & 2000 & $45 \%$ \\
\hline Micro/Pico & 1000 & $25 \%$ \\
\hline
\end{tabular}

Source: ADL 2001

A qualitative assessment of these sources suggests that there is little in the way of hard data that relates to the actual consumption for the total inventory of cell sites. By extension, even less is known as to whether average consumption per site has been increasing or declining, as a result from either changes in the mix of types of sites or overall technological change.

For this study, we have chosen to use a constant value of 2500 watts per site in the development of a series of historical consumption estimates. This value is slightly conservative relative to a weighted average of 2650 watts per site based on the estimates presented in Table 3.9. Based on an assumption that this average value per site has been relatively constant over time, Table 3.3 shows the estimated aggregate electricity usage on an annual basis from 1990 through 2004. The 1990-1993 figures for the numbers of cell phone sites are purely judgmental, based on the presumption that the number of cell sites was very small prior to 1990 . The 2001 ADL study cites the total number of cell sites as approximately 100,000 in the fourth quarter of 2000 (from data supplied by CTIA). For this study, the number of cell sites for 1995-1999, and 2001-2003 are derived by means of simple linear interpolation of the cellular sites reported by CTIA. For 2005, we assumed that the number of sites increased by 15,000 , a slightly conservative estimate based on the implied growth between 2000 and 2004.

If the average cell site does, in fact, use about 2500 watts, the electricity consumption for this end use is still very small. By 2004, the estimated electricity consumption is just under 4 TWh, or less than 0.4 percent of total commercial electricity sales as reported via the EIA-861.

\footnotetext{
${ }^{31}$ While CTIA publishes this data annually, the report is available only through purchase — not made for this study.
} 
Table 3.9. Estimated Electricity Consumption by Cell Phone Sites in the U.S.

\begin{tabular}{cccc} 
Year & $\begin{array}{c}\text { No. of } \\
\text { Towers }\end{array}$ & $\begin{array}{c}\text { Watts/ } \\
\text { Tower }\end{array}$ & TWh \\
\hline 1990 & 2,000 & 2,500 & 0.044 \\
1991 & 4,000 & 2,500 & 0.088 \\
1992 & 6,000 & 2,500 & 0.131 \\
1993 & 12,000 & 2,500 & 0.263 \\
1994 & 18,000 & 2,500 & 0.394 \\
1995 & 31,667 & 2,500 & 0.694 \\
1996 & 45,333 & 2,500 & 0.993 \\
1997 & 59,000 & 2,500 & 1.292 \\
1998 & 72,667 & 2,500 & 1.591 \\
1999 & 86,333 & 2,500 & 1.891 \\
2000 & 100,000 & 2,500 & 2.190 \\
2001 & 118,750 & 2,500 & 2.601 \\
2002 & 137,500 & 2,500 & 3.011 \\
2003 & 156,250 & 2,500 & 3.422 \\
2004 & 175,000 & 2,500 & 3.833 \\
2005 & 190,000 & 2,500 & 4.161
\end{tabular}

\subsection{Irrigation}

Up until 2003, EIA requested utilities to report their electricity sales for irrigation under the "Other" category. As shown in the bottom panel of Table 2.1, the "Other" category also included sales to public authorities, presumably including government-owned buildings that are sampled within the CBECS. Thus, some attempt to remove irrigation sales from the "Other" category is needed to develop a utilitybased electricity estimate that is more consistent with the CBECS.

The data related to electricity consumption for irrigation are sparse and inconsistent. Many utilities in the West offer special electric rates for irrigation. The principal data issue is the consistency in how this electricity consumption is reported to EIA.

The 2002 study for EPRI on water and sustainability (EPRI 2002) used an engineering approach to develop a national estimate for irrigation electricity use, but was not concerned with the classification and reporting issue. The engineering approach relied on the periodic surveys conducted by the U.S.

Geological Survey (USGS) as to the estimated quantity of water withdrawn for irrigation purposes. The USGS estimates that about 140 billion gallons of water per day are withdrawn for irrigation, with about two-thirds from surface water and one-third from ground water. Based on assumed estimates of the amount of electricity per million gallons of water $(700 \mathrm{kWh} /$ million gallons for groundwater, 300 $\mathrm{kWh} /$ million gallons for surface water), the report estimated total U.S. electricity consumption for irrigation to be $23.6 \mathrm{TWh}$ in 2000 .

Assuming the unit electricity requirements per million gallons have not changed over the past two decades, this estimate can be extrapolated backward using data on total withdrawals. The first column in Table 3.10 shows that the estimates of total water used for irrigation, developed at five-year intervals by USGS, have been essentially unchanged over the past few decades. As irrigation use does show year-toyear variation with water availability and weather conditions, we have chosen to ignore the slightly lower estimate for 1990. Thus, as a simplification, we assume that annual consumption has remained constant at the 23.6 TWh estimated in the EPRI report. 
No effort was made to corroborate this value with estimates developed from utility-based data. Several other aggregate estimates were found, but cannot easily be compared to the EPRI estimate. The Fifth Power Plan prepared by the Northwest Power Planning Council (NPPC 2005) indicated that electricity used for irrigation in the Northwest was about 5.5 TWh. ${ }^{32}$ The report plots annual data for irrigation and shows that variation of 10 to 15 percent from one year to the next is not uncommon. No discernable trend over the past twenty years is apparent. The NPPC data would suggest that Northwest electricity consumption for irrigation purposes is about one-quarter of the national estimate for irrigation, a figure that appears reasonable on the surface but not one that we have tried to verify.

A second source (suggested to us by EIA) was the Rural Utility Service (RUS) within the U.S. Department of Agriculture. ${ }^{33}$ The RUS is responsible for a federal loan program to rural electricity cooperatives. As part of their data collection efforts, the RUS asks borrowing utilities to report electricity sales for irrigation. In the 2004 statistical report for the RUS, the total of such sales was $3.7 \mathrm{TWh}$, based on the data supplied by approximately 600 cooperatives and other rural entities. ${ }^{34}$ While irrigation is likely a major end use for these RUS members, as a whole it appears that the reported sales may only account for between 10 and 20 percent of total electricity used for irrigation in the nation. ${ }^{35}$

As part of the effort to estimate irrigation use, some investigation of the utility-specific data from the 861 survey posted by EIA on its website was made. Of particular interest were changes in the reported electricity use by customer class before and after the revised 861 survey in 2003 . The focus was on selected utilities in the Northwest that are known to have significant sales for irrigation (under one or more rate schedules for that use.). The apparent inconsistency across utilities in the treatment of this data item was startling.

For two large investor-owned utilities serving the Northwest, the entries for electricity sales in the "Other" category were zero in the spreadsheet for the year 2000. Telephone calls to staff in both utilities indicated that one utility had historically classified irrigation sales as industrial and the other utility as commercial (not "Other"). For the 2004 survey, both utilities appeared to classify irrigation sales under industrial (as instructed by EIA-861), based on the relatively large number of industrial customers.

The same cursory examination was conducted for a small sample of about a dozen public utilities, primarily Public Utility Districts in Washington State (and two irrigation-based utilities in California). Two of these utilities classified irrigation sales under industrial prior to the 2003 change in the 861 survey. The other utilities had classified the sales under "Other" as was the guidance provided by EIA. In 2004 , one more utility reclassified irrigation sales to industrial, followed by four more in 2005 . Four utilities appear to continue to classify irrigation sales with commercial. Ideally, if all utilities had immediately reclassified irrigation sales as industrial, the published commercial sector total consumption

\footnotetext{
${ }^{32}$ The NPPC plan covers the states of Washington, Oregon, Idaho, and Montana.

33 The RUS was formerly, and perhaps more commonly, known as the Rural Electrification Administration.

${ }^{34}$ Personal communication with Karen Larsen, RUS, on September 14, 2006.

${ }^{35}$ The historical data in the RUS reports could provide an indicator of the year-to-year variation in irrigation electricity use on a national basis. However, an effort to obtain and develop more accurate annual estimates of irrigation electricity was deemed unlikely to substantively change any of the conclusions in this study.
} 
Table 3.10. Estimates of Irrigation Electricity Use (and Adjustments to Reported Data)

\begin{tabular}{|c|c|c|c|c|c|}
\hline & $\begin{array}{c}\text { Water } \\
\text { Withdrawals } \\
\text { (bil. gal.) }\end{array}$ & $\begin{array}{l}\text { Total } \\
\text { Electricity } \\
\text { Use } \\
\text { (TWh) }\end{array}$ & $\begin{array}{l}\text { Irrigation } \\
\text { Use } \\
\text { Included in } \\
\text { Pre-2003 } \\
\text { Commercial } \\
\text { Series } \\
\text { (TWh) }\end{array}$ & $\begin{array}{c}\text { Reclassifed } \\
\text { Commercial } \\
\text { Sales from } \\
\text { Change in } \\
\text { 861Survey } \\
\text { (TWh) }\end{array}$ & $\begin{array}{c}\text { Net } \\
\text { Change } \\
\text { in } \\
\text { Published } \\
\text { AER } \\
\text { (TWh) }\end{array}$ \\
\hline 1985 & 137 & 23.6 & 18.9 & & -18.9 \\
\hline 1986 & & 23.6 & 18.9 & & -18.9 \\
\hline 1987 & & 23.6 & 18.9 & & -18.9 \\
\hline 1988 & & 23.6 & 18.9 & & -18.9 \\
\hline 1989 & & 23.6 & 18.9 & & -18.9 \\
\hline 1990 & 137 & 23.6 & 18.9 & & -18.9 \\
\hline 1991 & & 23.6 & 18.9 & & -18.9 \\
\hline 1992 & & 23.6 & 18.9 & & -18.9 \\
\hline 1993 & & 23.6 & 18.9 & & -18.9 \\
\hline 1994 & & 23.6 & 18.9 & & -18.9 \\
\hline 1995 & 134 & 23.6 & 18.9 & & -18.9 \\
\hline 1996 & & 23.6 & 18.9 & & -18.9 \\
\hline 1997 & & 23.6 & 18.9 & & -18.9 \\
\hline 1998 & & 23.6 & 18.9 & & -18.9 \\
\hline 1999 & & 23.6 & 18.9 & & -18.9 \\
\hline 2000 & 137 & 23.6 & 18.9 & & -18.9 \\
\hline 2001 & & 23.6 & 18.9 & & -18.9 \\
\hline 2002 & & 23.6 & 18.9 & & -18.9 \\
\hline 2003 & & 23.6 & 18.9 & 10 & -8.9 \\
\hline 2004 & & 23.6 & 18.9 & 13 & -5.9 \\
\hline 2005 & & 23.6 & 18.9 & 16 & -2.9 \\
\hline
\end{tabular}

for 2003-2005 could be deemed to be purged of this end use. Unfortunately, that does not appear to be the case.

Given this inconsistent treatment of irrigation use, a two-step procedure was conducted in an effort to come up with an approximate magnitude of the irrigation electricity use that is included in EIA's commercial sector electricity estimates. The first step was to reconstruct the 2003-2005 estimates as they might have been reported had EIA not changed the survey form in 2003. That step is intended to remove some irrigation sales from the industrial sector that were moved from commercial or the "Other" category in 2003. After this step we assume that additional irrigation electricity use was transferred in both 2004 and 2005 from commercial to industrial classification. The change between 2003 and and 2004 is assumed to be higher than that in the succeeding year. From Figure 2.5, it can be imputed that between 1.5 and 2.4 TWh alone was transferred from commercial sales to industrial sales in Idaho (reporting by Idaho Power). The magnitude of these adjustments is shown in column 4 of Table 3.10. By 2005, we assume that all but about 15 percent of the irrigation electricity sales have been moved to the industrial sector, thus the adjustment to the reported commercial electrical sales is relatively small for that year.

As we noted earlier, it appears that not all utilities reclassified irrigation sales to the industrial sector beginning with the 861 survey for 2003. Accordingly, we have simply tried to discern the discontinuity in the commercial and industrial series that results from those utilities that did, in fact, follow the EIA guidance to classify irrigation as industrial use. Based on the 2004 Annual Survey of Manufactures (U.S. Census Bureau 2005), the percentage increase in total manufacturing electricity use was about 1 percent 
between 2002 and 2003. We assume that this same percentage increase roughly applied to the industrial sector as a whole (including agriculture, mining, and construction, as well as manufacturing). Based on this assumption, the increase in industrial sales would have been about $10 \mathrm{TWh}$, based on the data shown in column three of Table 2.2. As the reported increase in industrial sales in the AER was just over 20 $\mathrm{TWh}$, we can infer that about $10 \mathrm{TWh}$ of the increase was due to irrigation sales being reclassified. Thus, to put commercial sales on the pre-2003 definitional basis for 2003, we simply add $10 \mathrm{TWh}$ to the reported sales. This change is shown in column four in Table 3.10. The published and adjusted electricity series for both commercial and industrial sectors are plotted in Figure 3.2. We need to make clear that the adjusted series in the figure are an approximation to what might have been the reported consumption had EIA not changed its classification of irrigation sales in 2003.

After we make the adjustment, the historical commercial sales series are reasonably consistent over time. From our cursory examination of the utility-specific data, we know that some irrigation sales were reported as industrial prior to 2003. Moreover, in areas of the U.S. where irrigation is not common and no special irrigation rate schedules are offered by utilities, some irrigation electricity may be included in residential sales (although, for larger farms, agricultural electricity use may be included in either commercial or industrial sales.)

Unfortunately, without making a detailed utility-by-utility analysis, we do not have much empirical evidence to support any assumption as to the share of irrigation electricity use that had been historically reported as commercial sales. Nevertheless, based on our perusal of the 861 utility-specific data in for

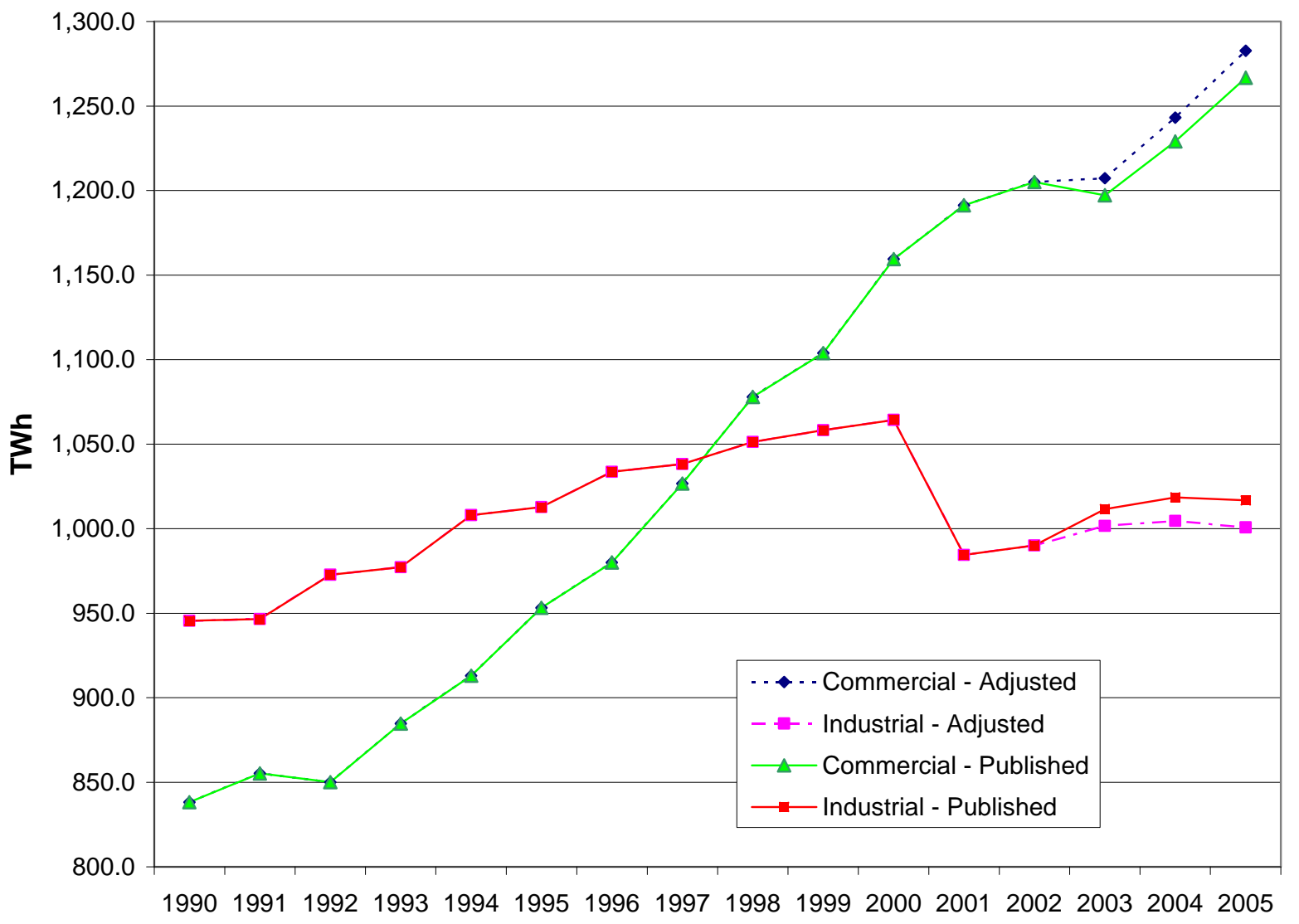

Figure 3.2. Published and Adjusted Electricity Series for Irrigation Reclassification 
2002, we believe most of the sales prior to 2003 were classified as commercial sales. For this study, we assume that 80 percent of such sales have been included in the commercial sector historically (either reported as Commercial or in the "Other" category prior to 2003). Applying this assumption to the total irrigation electricity sales derived from the EPRI report, we have a basis for adjusting the published commercial sales series. Those adjustments are shown as a series of negative numbers in the last column of Table 3.10. The adjustment is smaller in 2003 and later years as the published commercial sector sales reflect some reclassification from commercial to industrial based on the revised 861 survey form. 


\section{Total Impact of Commercial Sector Adjustments}

Based upon the analysis presented in Sections 2 and 3, the total impact of adjustments - from reclassification between industrial and commercial sales and the deduction of sales attributable to various types of non-enclosed equipment to commercial sector total electricity sales-is modest. Table 4.1 summarizes the findings quantified from this work. The largest change in any component is the electricity sales that have been reclassified from industrial to commercial since 1990. Column two of the table shows the estimated consumption to be subtracted from the published series that will adjust the older data to be consistent with the most recent classification and reporting conventions employed by the utilities (method $\mathrm{B}$ as explained in Section 2.2). Figure 4.1 provides a graphical look at the published and adjusted totals.

In looking at the period 1992 through 2002, the net effect of all of these adjustments trims about eight percent from total growth in reported commercial electricity sales. While that magnitude is still insufficient to account for differences between the higher trends in electricity sales and intensity based on the supply-side (EIA-861) information versus the trends implied by the various CBECS as shown in Section 1, the adjustments do bring these two estimates somewhat closer together. While the reclassification between industrial and commercial sales is responsible for an acceleration of commercial sector sales during the 1990s, the growth rate of non-enclosed commercial equipment appears to be slower than that for buildings. Over a longer period that covers the mid-1980s through the 2003-2005 period, the growth rates between the published and adjusted series are very close to one another, as these influences (reclassification and non-enclosed equipment) roughly offset each other. 
Table 4.1. Total Impact of Reclassification and Non-enclosed Equipment on Commercial Electricity Sales (Terawatt-hours)

\begin{tabular}{|c|c|c|c|c|c|c|c|c|c|}
\hline Year & $\begin{array}{l}\text { Published } \\
\text { Supply- } \\
\text { Based } \\
\text { (AER) }\end{array}$ & $\begin{array}{l}\text { Reclassifi- } \\
\text { cation - } \\
\text { Method B } \\
\text { (subtract) }\end{array}$ & $\begin{array}{l}\text { Outdoor } \\
\text { Lighting }\end{array}$ & $\begin{array}{l}\text { Water } \\
\text { Supply and } \\
\text { Treatment }\end{array}$ & $\begin{array}{c}\text { Cell } \\
\text { Towers }\end{array}$ & Irrigation & $\begin{array}{l}\text { PNNL } \\
\text { Adjusted } \\
\text { Total }\end{array}$ & $\begin{array}{c}\text { Difference } \\
\text { (PNNL } \\
\text { Adjusted - } \\
\text { Published } \\
\text { Total) }\end{array}$ & $\begin{array}{c}\text { Ratio } \\
\text { (PNNL } \\
\text { Adjusted/ } \\
\text { Published } \\
\text { Total }\end{array}$ \\
\hline 1983 & 620.3 & -16.5 & 19.0 & 50.2 & 0 & 18.9 & 548.6 & -71.7 & 0.884 \\
\hline 1984 & 663.7 & -23.2 & 19.4 & 50.7 & 0 & 18.9 & 597.8 & -65.8 & 0.901 \\
\hline 1985 & 689.1 & -23.5 & 19.8 & 51.2 & 0 & 18.9 & 622.7 & -66.4 & 0.904 \\
\hline 1986 & 714.7 & -23.7 & 20.2 & 51.8 & 0 & 18.9 & 647.6 & -67.1 & 0.906 \\
\hline 1987 & 744.1 & -24.7 & 20.6 & 52.3 & 0 & 18.9 & 677.0 & -67.1 & 0.910 \\
\hline 1988 & 784.0 & -25.8 & 20.9 & 52.8 & 0 & 18.9 & 717.1 & -66.9 & 0.915 \\
\hline 1989 & 810.9 & -26.2 & 21.3 & 53.4 & 0 & 18.9 & 743.4 & -67.4 & 0.917 \\
\hline 1990 & 838.3 & -26.6 & 21.7 & 54.1 & 0.04 & 18.9 & 770.1 & -68.1 & 0.919 \\
\hline 1991 & 855.2 & -26.9 & 21.9 & 54.9 & 0.09 & 18.9 & 786.4 & -68.9 & 0.919 \\
\hline 1992 & 850.0 & -32.5 & 22.2 & 55.7 & 0.13 & 18.9 & 785.7 & -64.3 & 0.924 \\
\hline 1993 & 884.7 & -28.4 & 22.4 & 56.4 & 0.26 & 18.9 & 815.1 & -69.6 & 0.921 \\
\hline 1994 & 913.1 & -27.5 & 22.7 & 57.2 & 0.39 & 18.9 & 841.5 & -71.6 & 0.922 \\
\hline 1995 & 953.1 & -16.7 & 23.3 & 58.0 & 0.69 & 18.9 & 869.0 & -84.1 & 0.912 \\
\hline 1996 & 980.1 & -18.5 & 23.9 & 58.7 & 0.99 & 18.9 & 896.1 & -84.0 & 0.914 \\
\hline 1997 & $1,026.6$ & 2.6 & 23.3 & 59.5 & 1.29 & 18.9 & 921.1 & -105.5 & 0.897 \\
\hline 1998 & $1,078.0$ & 2.4 & 23.4 & 60.3 & 1.59 & 18.9 & 971.4 & -106.6 & 0.901 \\
\hline 1999 & $1,103.8$ & 2.4 & 24.6 & 61.1 & 1.89 & 18.9 & 994.9 & -108.9 & 0.901 \\
\hline 2000 & $1,159.3$ & 10.1 & 26.2 & 61.9 & 2.19 & 18.9 & $1,040.1$ & -119.3 & 0.897 \\
\hline 2001 & $1,191.2$ & 13.1 & 27.3 & 62.6 & 2.60 & 18.9 & $1,066.7$ & -124.5 & 0.895 \\
\hline 2002 & $1,205.1$ & 7.5 & 28.2 & 63.3 & 3.01 & 18.9 & $1,084.2$ & -120.9 & 0.900 \\
\hline 2003 & $1,197.2$ & 3.0 & 30.0 & 64.1 & 3.42 & 8.9 & $1,087.8$ & -109.4 & 0.909 \\
\hline 2004 & $1,229.0$ & 3.0 & 31.6 & 64.8 & 3.83 & 4.9 & $1,120.9$ & -108.1 & 0.912 \\
\hline 2005 & $1,266.7$ & 3.0 & 33.4 & 65.6 & 4.16 & 2.9 & $1,157.7$ & -109.0 & 0.914 \\
\hline
\end{tabular}

Figure 4.1 also compares the published and adjusted annual commercial sales along with the adjusted CBECS estimates. Based on the standard errors published on EIA's CBECS web site, the 95 percent confidence intervals are shown for each of the CBECS estimates. 


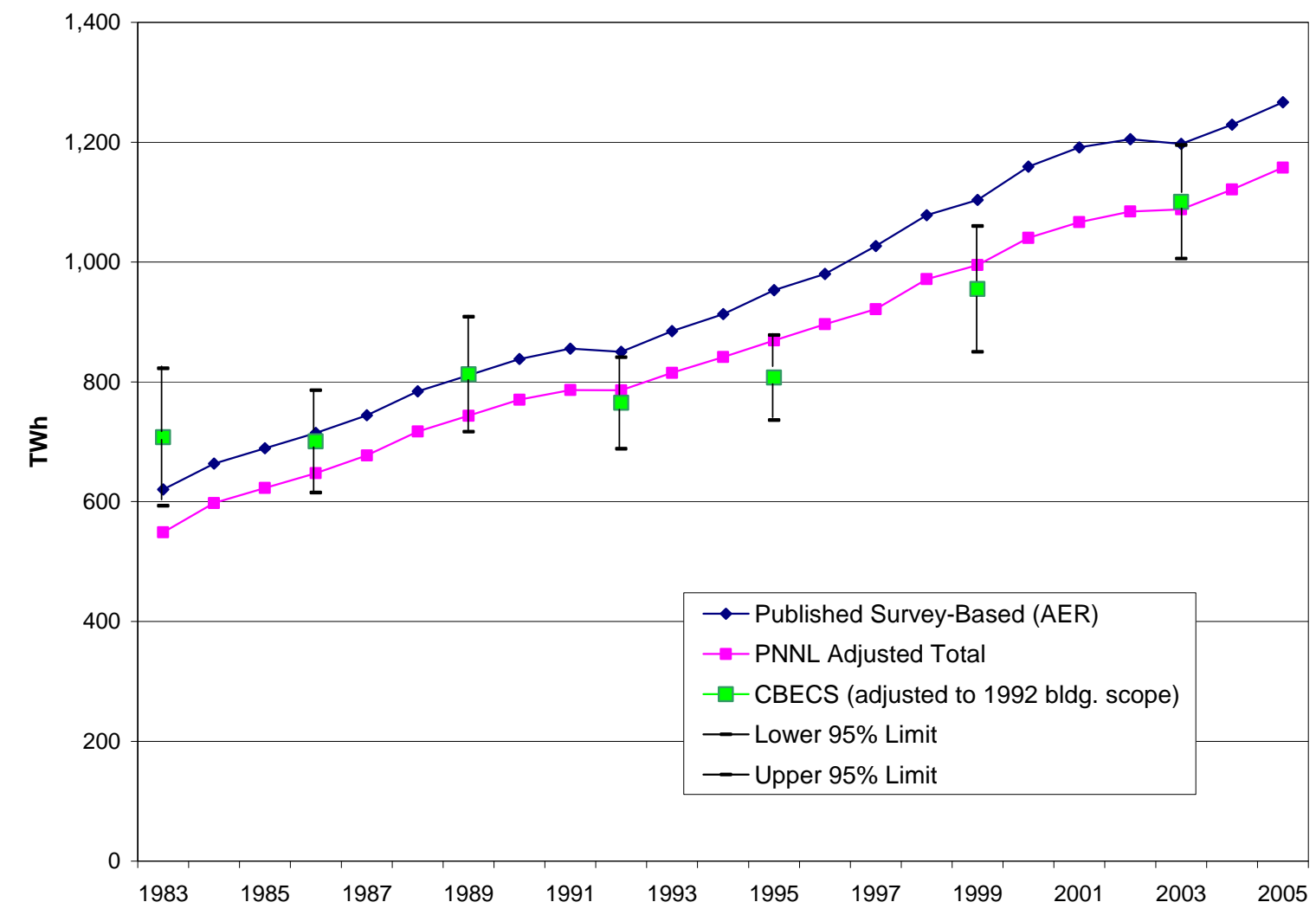

Figure 4.1. Total Commercial Sector Electricity Use, Published-AER vs. Adjusted Series (TWh)

Clearly, the most obvious result is that the CBECS and adjusted utility-based estimates show good agreement over the last four CBECS, although the 1992 CBECS is considerably below the adjusted supply survey estimate. Given the magnitude of the non-building energy consumption shown in Table 4.1, we would expect that the published utility-based estimates would exceed those of the CBECS in every year. However, the CBECS consumption estimates for the 1980s do not follow this pattern.

If the adjusted utility-based estimates can be considered to reasonably match the CBECS scope and definition, the 1983 CBECS estimate is much too high. The utility-based estimate is even below the lower 95 percent confidence limit. As the 1979 (not shown) and 1983 surveys were based on a different sampling procedure as compared to the later CBECS, one can attribute the difference to the way the sample was selected and converted into a national estimate. In 2001, EIA adjusted the published 1983 (and 1979) estimates for underreporting found to be evident in those surveys. Without reviewing the EIA method used to re-estimate the 1983 consumption, it appears that the adjustment may be on the high side. $^{36}$

More puzzling is the magnitude of the 1986 and 1989 CBECS relative to supply survey data. The 1986 CBECS used a new sampling procedure and EIA improved its overall methodology and statistical

\footnotetext{
${ }^{36}$ From the 95\% confidence ranges shown in Figure 4.1, the change between 1983 and 1986 could span a variety of positive or negative values. For a point estimate, however, it is implausible that electricity consumption declined between these years while the economy was emerging from the 1982 recession.
} 
methods as compared to the 1983 survey. The 1989 survey used the same sampling units (i.e., areas of the U.S. from which commercial buildings were selected), but employed an entirely different set of buildings. The 1992 survey was longitudinal with the 1986 survey. Except for buildings constructed between 1986 and 1992, the same buildings were used in both surveys. ${ }^{37}$ The lower $95 \%$ confidence limits for both the 1986 and 1989 surveys include the adjusted utility estimates, and so from a statistical standpoint we cannot reject the notion that these measures may come from the same population. Looking over the variation across all of the CBECS, with the exception of 1983, the discrepancies in the 1986 and 1989 surveys are not terribly out of line with adjusted supply survey data.

As our primary interest is the trend in overall electricity intensities in commercial buildings, annual intensities are calculated by dividing the adjusted utility-based consumption by the total estimates of floor space described briefly in Section 1. As the published CBECS intensities are based only on buildings that use electricity, we make a small adjustment to the amount of floor space. Over the six CBECS from 1983 through 1999, electricity was used in a range of 97 to 98 percent of total floor space, with an average of 97.5 percent. While not affecting the trend in the intensities over time, all of the annual floor space estimates have been reduced by a constant 2.5 percent (i.e., multiplied by 0.975 ) to better measure the absolute intensities of only those buildings served by electricity. This has effect in increasing the annual electricity intensities by 2.5 percent as compared to using the unadjusted floor space series.

Ideally, the derivation of the aggregate intensities from the utility-based data would employ a time series of floor space independent from the CBECS. Unfortunately, no such series is available. As described in Section 1, the floor space series used here is based on the CBECS but it should be noted that the series is not constructed as a simple interpolation between the CBECS data points. Rather, a perpetual inventory approach is followed in which new additions are added and retirements (demolitions and conversions) are subtracted from the stock. While the series is benchmarked to the 1989 CBECS, there is no explicit attempt to match the floor space estimates for the other CBECS. Thus, while the estimated amount of floor space may be relatively high or low compared to the "true" values, the overall trend of floor space is expected to be reasonably accurate.

Figure 4.2 compares the annual intensities based on the adjusted supply data to the various intensities derived from the CBECS. As mentioned in Section 1, the 1983 intensity is based upon a retabulation by EIA of the 1983 dataset. The intensities for the 1986, 1989, and 1992 are taken directly from the published Consumption and Expenditures reports for those years. For 1995, 1999, and 2003 the intensities are adjusted downward very slightly to reflect the slightly different building composition in these later surveys. ${ }^{38}$

\footnotetext{
${ }^{37}$ With the exception of buildings that were demolished or had changed use (e.g., to residential), or where no interview could be obtained.

${ }^{38}$ As discussed in Section 1, the 1995 CBECS and later CBECS exclude parking garages and commercial buildings in multibuilding industrial/manufacturing complexes. When estimates of the square footage and electricity use for these building types are included for these later years, the average all-building intensities are about $0.1 \mathrm{kWh} / \mathrm{sq}$. $\mathrm{ft}$. lower than the published values.
} 


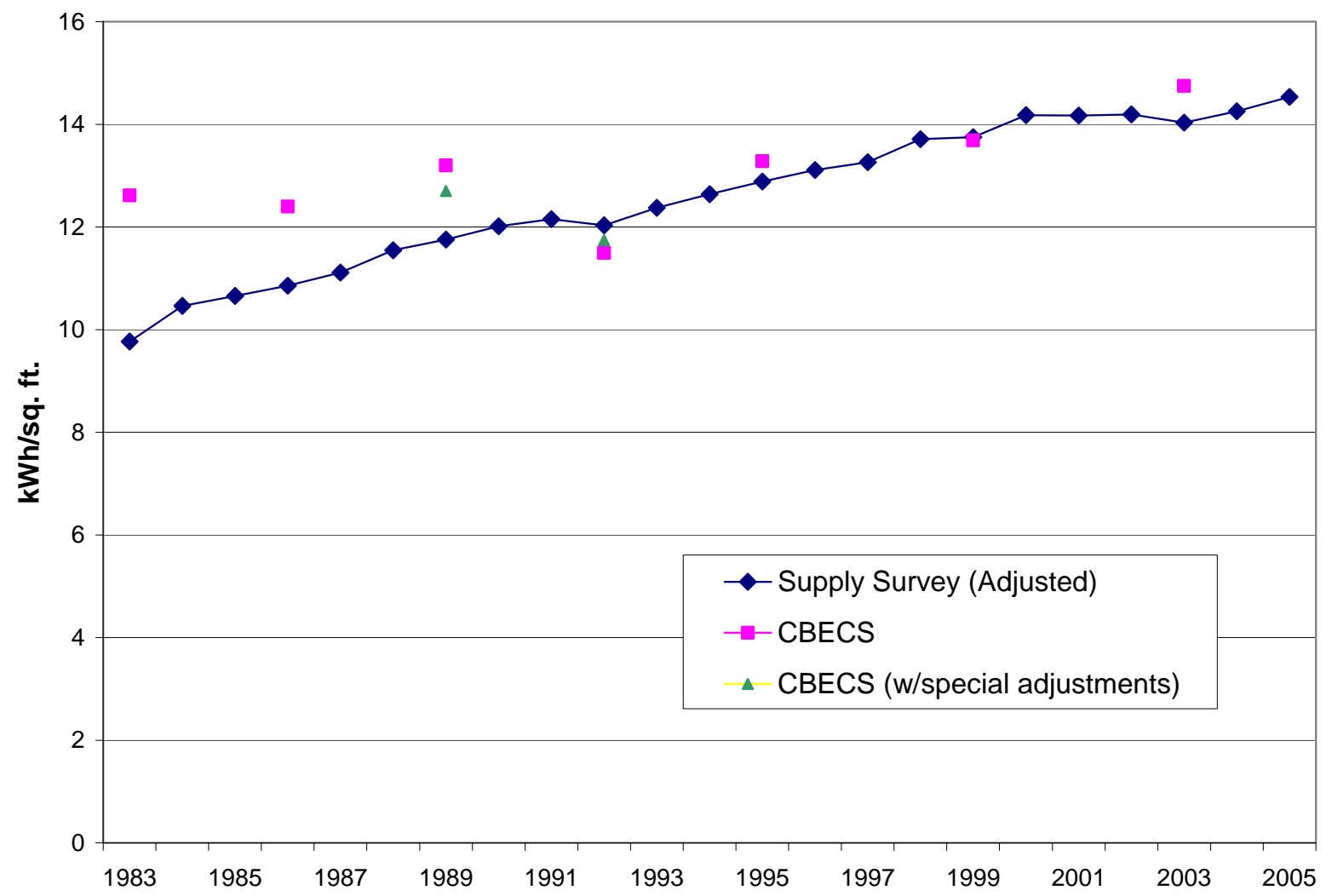

Figure 4.2. Comparison of Adjusted Intensities from the CBECS and Supply Survey Data

Because the annual floor space estimates do in fact approximately track the reported floor space in the various CBECS, the discrepancies between the intensity estimates mirror those shown for the consumption levels in Figure 4.1. The intensities follow very similar trends from the 1992 forward. The CBECS-based intensities are significantly higher during the 1980s.

After making all of the adjustments to the utility-based estimates, we are left with three possible explanations for the remaining divergence in these series:

1. The CBECS total electricity consumption estimates for 1986 and 1989 are too high, based on the particular sample of buildings chosen in the sample. This occurs even though the overall level of floor space is approximately correct. Thus, a comparison to later CBECS shows a rate of intensity growth that is too low.

2. The 1986 and 1989 CBECS estimates for both floor space and electricity consumption are too high. The floor space estimation procedure, which uses the level and age-distribution from the 1989 CBECS, thus shows too little growth in floor space over the period from the mid-1980s to late 1990s. In particular, the actual floor space is lower than what is shown in the 1986 and 1989 CBECS, which when combined with the supply-based consumption estimate would yield higher average intensities for this period.

3. There remains varying bias in the supply-based electricity consumption for the commercial sector. Apart from large reclassifications that could be detected at the state level, there is the possibility that light manufacturing facilities were being reclassified to accounts that were reported in the 861 survey as commercial or that commercial buildings that were reported as industrial sales in during the 1980 s were later reported as commercial sales. 
Even after the extensive analysis in this study, it is unclear which explanation may be the most plausible and it appears likely that some combination of all three effects accounts for this situation. With regard to the first explanation, a small effort was made to investigate whether sampling variation in the CBECS, by specific building types, may play some role. Figure 4.3 compares the published CBECS electricity intensities for 1986 through 1995. If one keeps in mind that the three building types with the largest shares of electricity consumption are mercantile and service, office, and warehouse (with over half of commercial building electricity use), the chart shows that the intensities for these buildings all decline significantly in 1992. This behavior primarily reflects the economic recession in that year. (That year also had a very cool summer that would reduce electricity intensity, but this effect is not apparent for all building types.)

However, a detailed analysis of the CBECS for 1992 indicates that the aggregate intensity (total electricity divided by total floor space) is lower than that implied by a constant weighting of the building intensities in Figure 4.3, as the composition of floor space in the CBECS sampling appears to have shifted to buildings with relatively lower intensities. Holding the composition the same as in 1986 CBECS (which is presumed to contain many of the same buildings as in the 1992 CBECS sample), the computed aggregate intensity for 1992 would be about $0.25 \mathrm{kWh} / \mathrm{sq}$. ft. higher. This adjusted intensity is shown in Figure 4.2 as the small (green) triangle for 1992 (sitting just above the square for the published CBECS values).

As shown in Figure 4.3, an anomaly appears to be the behavior of the 1989 intensity for the "other" building type. The 1989 value is roughly double that for any of the other survey years. If we lower the 1989 intensity for this building type by 50 percent, the overall aggregate intensity falls by $0.5 \mathrm{kWh} / \mathrm{sq}$. $\mathrm{ft}$. This adjustment is shown as the (green) triangle in the Figure 4.2 for 1989. Clearly, just this single adjustment helps to better rationalize the 1989 CBECS intensity with the supply-based estimate. Moreover, this adjustment is not influenced by the amount of floor space. (In terms of absolute electricity consumption, this adjustment would lower 1989 CBECS consumption by nearly $30 \mathrm{TWh}$, representing roughly forty percent of the difference between the CBECS and the adjusted supply estimate shown in Figure 4.1.)

To evaluate to degree to which the second explanation might influence some of the discrepancies shown in Figure 4.2 would require extended data analysis. If the floor space is overstated in the 1986 and 1989 CBECS, we would need to revamp the perpetual inventory methodology currently used to generate the annual floor space estimates. We have found that the 1989 and 1999 CBECS taken together can generate a plausible function for the estimating retirements from the commercial floor space series. If there is a discontinuity in the underlying CBECS floor space estimates beginning around the time of the 1992 CBECS, this would dramatically complicate the procedure to generate a consistent series over time. 


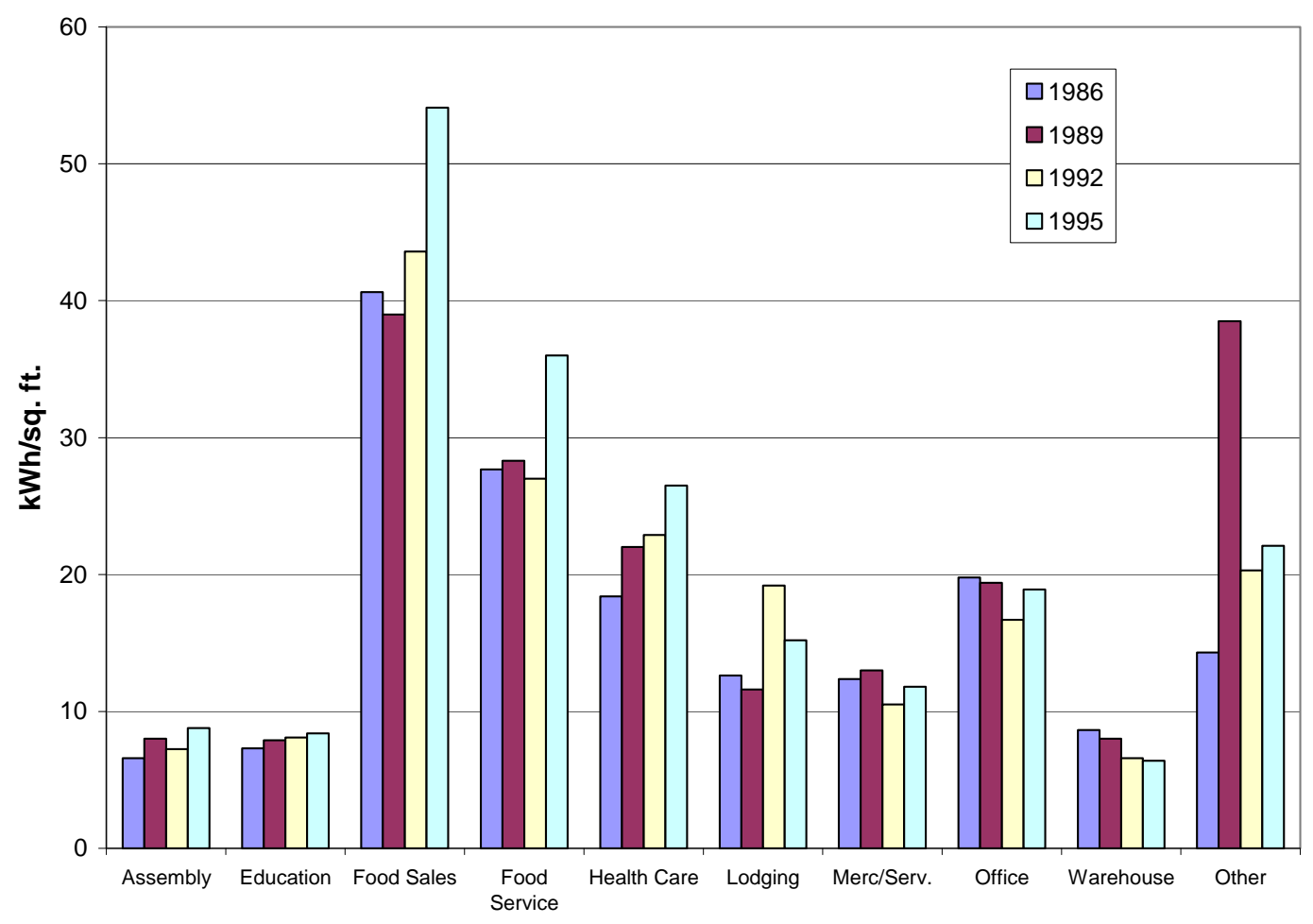

Figure 4.3. Electricity Intensities by Building Type: 1986, 1989, 1992 and 1995 CBECS

The third possible explanation gains some credence from some auxiliary information collected for the 1989, 1992, and 1995 CBECS. As EIA explicitly points out, a principal reason that a component of consumption may be in the CBECS totals but not in the supply survey totals is the differences in how customers are classified in the sales (supply survey) reporting system. Each utility has its own system of classifying accounts. When reporting via the 861 survey, utilities are assumed to take into account EIA's guidelines (that encourage classification along the Standard Industrial Classification or, more recently, the North American Industrial Classification System, as described in Table 2.1) to distinguish commercial customers from industrial customers as well as its own account classification.

For the three years listed above, the CBECS asked electricity suppliers as to how they classified each of the accounts for the CBECS sample. Table 4.2 summarizes those results with respect to electricity consumption. For 1989, we see from the table that only 75 percent of the CBECS buildings were classified strictly as commercial accounts by the supplying electric utility. Unclear is the interpretation of the "mixed" category. EIA suggests that these hybrid accounts are "probably included partly in commercial and partly in noncommercial totals" (EIA 1998, p. 359).

Unfortunately, in EIA's survey form the only question asked of the utility was "How do you classify this building/account in your records" (EIA 1995, p. 424). The choices provided were 1) Residential, 2) Commercial, 3) Industrial, 4) Commercial/ Industrial, and 5) Other. A more relevant, but slightly more difficult, question for the utility would have requested how this account was classified for purposes of reporting under the 861 survey. As the survey response for number (4) in the list above leads with the word Commercial, we believe it is likely much of this consumption was classified as commercial for the 861 survey. 
The most striking element from Table 4.2 is that over 14 percent of the electricity consumption in the 1989 CBECS sample was classified by the utilities as industrial. In the 1992 CBECS this percentage falls to just under 9 percent. For the $1995 \mathrm{CBECS}$, the table shows just over 4 percent of the buildings were classified as industrial. However, starting with this survey, the CBECS no longer included commercial buildings on multibuilding manufacturing sites, and so this further decline is not unexpected. As we mentioned in Section 2, the electricity consumption for many buildings on multibuilding industrial/manufacturing sites would likely be included in industrial sales.

This change in the scope for the 1995 CBECS means that we only have the change between 1989 and 1992 to provide any indication of reclassification between industrial and commercial accounts. This change of five percentage points between 1989 and 1992 in the fraction of electricity classified as industrial amounts does support the notion that at least some commercial buildings were reclassified from industrial to commercial accounts during this period.

One source of the change in the relative difference between the CBECS and supply-side electricity consumption estimates between 1989 and 1992 may be simply that that the 1989 sample just included a greater percentage of commercial buildings on multibuilding manufacturing sites. This supposition is borne out by the second-to-last line of Table 4.2 where an estimate of amount of consumption in these commercial buildings on manufacturing sites is estimated. ${ }^{39}$ Here the estimates indicate that the 1989 CBECS included roughly 30 TWh more electricity consumption from these buildings as compared to the 1992 CBECS (63.3 TWh - 30.3 TWh).

Using the micro-data from the 1992 CBECS, we calculated that just over 60 percent of the electricity consumption on these multibuilding industrial/manufacturing sites was classified by the utilities as industrial sales. The results of applying this percentage to the 1989 and 1992 values are shown in italics on the last line of Table 4.2. ${ }^{40}$ These estimates suggest that about 20 TWh of the 1989-1992 change in the differential between the CBECS and the supply survey estimates of electricity consumption can be

\footnotetext{
${ }^{39}$ The estimates of commercial building electricity use on manufacturing sites is based on the information published by EIA on their website devoted to examining commercial building energy trends: http://www.eia.doe.gov/emeu/consumptionbriefs/cbecs/cbecs_trends/siteelecconsumptiondetail.html

On this webpage, total site electricity consumption for 1989 and 1992 is shown using the 1995 building target population (scope). The difference between the published CBECS and the adjusted CBECS numbers for 1989 and 1992 include both commercial buildings on manufacturing sites and parking garages. An estimate of electricity used in parking garages is subtracted from this overall difference to yield the estimate for consumption of commercial buildings on manufacturing sites. Unfortunately, this estimate is not available for the 1986 CBECS.

${ }^{40}$ The total consumption for multibuilding industrial/manufacturing facilities derived from the 1992 micro-data is 32.7 TWh, of which 20.3 TWh was classified by utilities as industrial sales $(20.3 / 32.7=62 \%)$. The absolute level of multibuilding industrial/manufacturing electrical use is about $10 \%$ higher than that implied from the EIA website cited in the previous footnote and shown in Table 4.2 (30.7 TWh). We did not try to resolve this minor discrepancy with EIA. Unfortunately, the micro-data to analyze the utility classification of electricity sales by building activity was not readily available for the 1989 CBECS.
} 
attributed to the smaller representation of multibuilding industrial/manufacturing facilities for which electricity sales were classified as industrial. ${ }^{41}$

To sum up, we conclude that the a portion of the change between 1989 and 1992 (in the difference between the CBECS and adjusted supply survey estimates) might be explained by both the effects of different CBECS samples (i.e., including more than twice as much consumption in multibuilding industrial/ manufacturing facilities in the 1989 CBECS as compared to the 1992 CBECS) as well as some reclassification of other commercial buildings (i.e., not on multibuilding manufacturing sites) by utilities from industrial to commercial sales. This second effect implies that the (adjusted) supply survey estimate for 1989 may be too low as compared to more recent data and thus may not provide an historically consistent trend.

The real difficulty is that the sample of buildings in the CBECS will show some variation in the percentage of buildings whose electricity consumption is reported by the utilities as commercial (or conversely, as industrial). ${ }^{42}$ However, as we have shown in Section 2 with regard to reclassifications detectable at the state level, it is also clear that the actual percentage of commercial buildings whose consumption is reported by utilities to EIA as commercial has changed over time (and typically has increased). Without a very detailed historical examination of the supply survey data prior to 1990, we have little basis to further adjust the consumption estimates shown in Table 4.1 that are derived from this source. $^{43}$

Unfortunately, any rationalization of the 1986 data points - discrepancy between the CBECS and supplyside information--is much more difficult. No particular anomaly in the CBECS intensities is apparent that would provide any basis to question the CBECS overall consumption and intensity (as per Figure 4.3). The 1986 CBECS did not include any questions as to how the electricity consumption for the sampled building was classified by the utility. Thus, we can make a conjecture that sampling variation in the CBECS is responsible for a relatively high estimate of consumption and intensity or that even a higher percentage of commercial building electricity use may have been classified by utilities as industrial in the mid-1980s. Indeed, both factors could explain some of the discrepancy.

\footnotetext{
${ }^{41}$ This assertion presumes that the representation of commercial buildings not in multibuilding manufacturing sites is the same between the 1989 and 1992 CBECS. Thus, the higher proportion of commercial buildings on such sites in 1989 as compared to 1992 would imply a higher total level of consumption, holding all other factors constant.

${ }^{42}$ For sake of clarity, assume that a constant " $x$ " percent of the electricity used in all commercial buildings is reported by utilities in the EIA-861 survey as industrial consumption. The CBECS could report a percentage higher or lower than $x$ percent depending on the nature of the sample drawn. No estimates of the error bounds to the percentages shown in Table 4.2 are available. Thus, the 1989-1992 decline of 5 percentage points in fraction of CBECS buildings classified as industrial could result from underlying trends in the actual population or from sampling variation (or both). The portion resulting from changes in how the population of commercial buildings is classified would suggest that we adjust the supply-derived consumption (and intensities) upward for the 1980s to improve the historical consistency of the estimates. We have elected to not try to make any adjustment to supply data based solely on the information derived from the CBECS.

${ }^{43}$ Data for the EIA-861 survey are available only from 1986 forward and the detailed utility-level information is available on the EIA website only from 1990.
} 
Table 4.2. Utility Account Classification of Commercial Building Electricity: 1989, 1992, and 1995

\begin{tabular}{|c|c|c|c|c|c|c|c|}
\hline \multirow{2}{*}{$\begin{array}{l}\text { Supplier Account } \\
\text { Classification }\end{array}$} & \multirow{2}{*}{$\begin{array}{l}\text { Corresponding } \\
\text { EIA Sales Sector }\end{array}$} & \multicolumn{2}{|c|}{1989} & \multicolumn{2}{|c|}{1992} & \multicolumn{2}{|c|}{1995} \\
\hline & & TWh & $\%$ & TWh & $\%$ & TWh & $\%$ \\
\hline \multicolumn{8}{|l|}{ All Buildings, All } \\
\hline Accounts & & 812.7 & $100.0 \%$ & 764.7 & $100.0 \%$ & 764.4 & $100.0 \%$ \\
\hline Commercial & Commercial & 608.7 & $74.9 \%$ & 597.9 & $78.2 \%$ & 625.1 & $81.8 \%$ \\
\hline Mixed & (Commercial ?) & 81.8 & $10.1 \%$ & 94.4 & $12.3 \%$ & 104.0 & $13.6 \%$ \\
\hline Residential & Residential & 4.7 & $0.6 \%$ & 4.4 & $0.6 \%$ & 5.6 & $0.7 \%$ \\
\hline Industrial & Industrial & 116.9 & $14.4 \%$ & 67.7 & $8.9 \%$ & 33.7 & $4.4 \%$ \\
\hline \multicolumn{8}{|l|}{ Commercial Bldgs. - } \\
\hline $\begin{array}{l}\text { Manufacturing Sites } \\
\text { Classified as }\end{array}$ & & 63.3 & & 30.3 & & Not in survey & \\
\hline Industrial by Suppliers & & 39.2 & & 18.7 & & Not in survey & \\
\hline
\end{tabular}

To this point, we have attempted to rationalize what appears to be the relatively high consumption for the 1986 and 1989 CBECS. Another perspective is that, in terms of intensities shown in Figure 4.2, the 1992 data point is anomalous. By visually "throwing out" this data point, the historical series based upon all of the other CBECS follow a very gradually upward trend. In fact, a linear trend through all of the CBECS points, excluding 1992, would yield a very good statistical fit.

The CBECS trend rate of growth based upon this slightly altered sample would still be lower than that based upon the supply survey. However, what investigation of the supply survey data that has been made during the course of this study suggests that this source may provide only a very approximate measure of the true electricity used by commercial versus industrial establishments. Changes in the character of electricity loads of the industrial and commercial customers could be reflected in many ways across different utilities, depending upon the rate structures in place. Rate structures change due to shifting economic and regulatory conditions, as well as the makeup of the electric utility industry. Thus, we have reason to be skeptical as well that the supply survey data is representing accurately the trend growth in commercial building electricity use.

\subsection{Conclusion}

This study has developed a selected set of adjustments to the commercial sector electricity sales data that appear to yield a reasonably accurate representation of annual commercial building consumption, as supported by a comparison to total electricity estimates made by the various CBECS since 1992. Two major adjustments to the sales data have been made. The first removes the effects of major reclassifications between industrial and commercial sectors that can be identified from state-level annual consumption data. The second adjustment involves the development of historical estimates of nonenclosed equipment (outdoor lighting, water supply and treatment, cell towers, and irrigation)

However, the total of all the adjustments (shown in the second to last column of Table 4.1) is not sufficient to explain much of the difference between the aggregate electricity intensity trends derived from the two data sources. Over the period 1985 to 2005, the adjusted intensity based on the supply 
survey actually increases slightly faster (1.53 percent/yr) than the intensity based on the published commercial sales data (1.47 percent/yr) that was shown in Figure 4.2. However, the correspondence between the absolute intensities based on the adjusted supply survey estimates and the CBECS since 1992 is close.

While we have made substantial progress in rationalizing some of the differences between the CBECS and supply-based estimates of aggregate electricity intensity, we reluctantly admit that the trends based on data prior to 1990 are still unclear. Even ignoring the CBECS data point for 1983, the trend rate of change of electricity intensity implied by the set of CBECS that includes the 1986 and 1989 surveys is still somewhat lower than that based on supply data.

Several hypotheses were put forward in an attempt to "explain" the unusually high values of CBECS consumption (and concomitant intensities) for 1986 and 1989 relative to the supply-based estimates. One explanation deals with the sampling variation of the CBECS, in particular focusing on a very high consumption and intensity for the "Other Buildings" category in the 1989 CBECS. We also investigated the implications of the data collected in the 1989 and 1992 CBECS as to how the utilities classified the CBECS buildings with regard to their overall reporting of electricity sales to EIA. For 1989, this line of inquiry appears to also to rationalize some of the differences in the 1989 data sources. Unfortunately, we have no comparable explanation for 1986.

From another perspective, however, if the 1992 CBECS is omitted, a gradual and relatively consistent trend of increasing intensities is provided by the the full set of CBECS. At this point, no arguments are suggested as to why the 1992 CBECS may represent an anomalous data point. This perspective still indicates that the CBECS trend growth in electricity consumption and aggregate intensity is lower than that suggested by the supply survey data. However, it is plausible that the CBECS estimates do provide the more accurate picture of long-term intensity trends. The supply survey data is subject to variety of factors that may be biasing the reported consumption for both the commercial and industrial sectors.

At this point, we reluctantly admit that there is no satisfactory explanation of the discrepancy between the adjusted supply survey consumption estimates and the CBECS when analyzed over the past several decades. The correspondence between the sources is closer in the time period after 1992 and for many purposes this shorter historical perspective is sufficient. Finally, it is recommended that any broad statements about trends in overall commercial electricity always be accompanied with a reference to the underlying data source. 



\section{References}

ADL. 2002. Energy Consumption by Office and Telecommunications Equipment in Commercial Buildings, Vol. I: Energy Consumption Baseline. Arthur D. Little, Inc., New York.

Architectural Energy Corporation. 2003. Design Criteria and Energy Savings Report, Deliverable 5.3.1b and $c$. Report submitted to the California Energy Commission, San Francisco, California.

Barton, Bruce. 2004. "The Antenna Dilemma," Los Altos Town Crier, April 14, 2004. Accessed on May 22, 2007 at http://www.latc.com/2004/04/14/news/news01.html (last updated April 14, 2004).

California Energy Commission. 2003. California Outdoor Lighting Baseline Assessment. CEC-500-03082-A-18. Report prepared by RLW Analytics, Sonoma, California.

EPRI. 2002. Water and Sustainability: U.S. Electricity Consumption for Water Supply \& Treatment-The Next Half Century. Electric Power Research Institute, Palo Alto, California.

Energy Information Administration. 1990. Energy Consumption by End-Use Sector: A Comparison of Measures by Consumption and Supply Surveys. DOE/EIA-0533. U.S. Department of Energy.

Washington, D.C.

Energy Information Administration. 1995. Commercial Buildings Energy Consumption and Expenditures 1992. DOE/EIA-0318(92). U.S. Department of Energy. Washington, D.C.

Energy Information Administration. 1998. A Look at Commercial Buildings in 1995: Characteristics, Energy Consumption, and Energy Expenditures. DOE/EIA-0625(95) U.S. Department of Energy. Washington, D.C.

Energy Information Administration. 2005. Electric Power Annual 2004. DOE/EIA-0348(2004) U.S. Department of Energy. Washington D.C.

Navigant Consulting, Inc. 2002. U.S. Lighting Market Characterization. Vol. I: National Lighting Inventory and Energy Consumption Estimate. Prepared for U.S. Department of Energy, Office of Energy Efficiency and Renewable Energy, Building Technologies Program. Navigant Consulting, Inc. Washington D.C.

Navigant Consulting, Inc. 2003. Energy Savings Estimates of Light Emitting Diodes in Niche Lighting Applications. Prepared for U.S. Department of Energy, Office of Energy Efficiency, Building Technologies Program. Navigant Consulting, Inc., Washington D.C.

Northwest Power Planning Council. 2005. The Fifth Northwest Electric Power and Conservation Plan. Volume 3. Appendix A: Demand Forecast. Accessed May 21, 2007 at http://www.nwcouncil.org/energy/powerplan/plan/Appendix\%20A\%20(Demand\%20Forecast).pdf (last updated May 2005).

Pierce, Barbara. 1994. Office of Building Technologies Evaluation and Planning Report BNL-52426.

Prepared for U.S. DOE, Office of Energy Efficiency and Renewable Energy, Office of Building Technologies by Brookhaven National Laboratory, Upton, New York. 
TIAX. 2006. Commercial and Residential Sector Miscellaneous Electricity Consumption: Y2005 and Projections to 2030. Prepared for U.S. Department of Energy, Energy Information Administration. Reference No. D0366. TIAX LLC, Cambridge, MA.

U.S. Census Bureau. 2003. Statistical Abstract of the U.S. Table No. 1088, "State Motor Vehicle Registration, 1980 to 2001, and Licensed Drivers and Motorcycle Registrations by State: 2001." Washington, D.C.

U.S. Census Bureau. 2005. Annual Survey of Manufactures, Statistics for Industry Groups and Industries: 2004. Table 4, "Purchased Fuels and Electric Energy Used for Heat and Power by Industry Groups and Industries: 2004 and Earlier Years." Accessed May 22, 2007, at http://www.census.gov/prod/2005pubs/am0431gs1.pdf.

U.S. Census Bureau. 2006. Statistical Abstract of the U.S: 2007. Table No. 1063, "Highway Mileageurban and rural by Ownership: 1980 to 2004." Washington, D.C.

Wired. 2005. "Cell-Phone Tower Debate Grows." Accessed May 21, 2007 at

http://www.wired.com/gadgets/wireless/news/2005/08/68600 (last updated August 20, 2005). 
PNNL-16820

\section{Distribution}

(All distribution made electronically)

\section{OFFSITE}

Drury Crawley

U.S. Department of Energy

EERE-Building Technologies

Program (EE-2J)

1000 Independence Ave., S.W.

Washington DC, 20585

Jerry Dion

U.S. Department of Energy

EERE-Building Technologies

Program (EE-2J)

1000 Independence Ave., S.W.

Washington DC, 20585

Terry Logee

U.S. Department of Energy

EERE-Building Technologies

Program (EE-2J)

1000 Independence Ave., S.W.

Washington DC, 20585

John D. Ryan

U.S. Department of Energy

EERE-Building Technologies

Program (EE-2J)

1000 Independence Ave., S.W.

Washington DC, 20585

David Boomsma

U.S. Department of Energy

EERE-Office of Planning,

Budget and Analysis (EE-3B)

1000 Independence Ave., S.W.

Washington DC, 20585

Jeff Dowd

U.S. Department of Energy

EERE-Office of Planning,

Budget and Analysis (EE-3B)

1000 Independence Ave., S.W.

Washington DC, 20585
Erin Boedecker

U.S. Department of Energy

Energy Information Administration

Demand and Integration Division (EI-84)

1000 Independence Ave., S.W.

Washington DC, 20585

Eugene Burns

U.S. Department of Energy

Energy Information Administration

Energy Consumption Division (EI-63)

1000 Independence Ave., S.W.

Washington DC, 20585

Susan Holte

U.S. Department of Energy

Energy Information Administration

Office of the Administrator

1000 Independence Ave., S.W.

Washington DC, 20585

Thomas Leckey

U.S. Department of Energy

Energy Information Administration

Electric Power Division (EI-53)

1000 Independence Ave., S.W.

Washington DC, 20585

\author{
Alan Swenson \\ U.S. Department of Energy \\ Energy Information Administration \\ Energy Consumption Division (EI-63) \\ 1000 Independence Ave., S.W. \\ Washington DC, 20585 \\ Phillip Tseng \\ U.S. Department of Energy \\ Energy Information Administration \\ Statistics and Methods Group (EI-70) \\ 1000 Independence Ave., S.W. \\ Washington DC, 20585
}

Dist. 1 
Steve Wade

U.S. Department of Energy

Energy Information Administration

Demand and Integration Division (EI-84)

1000 Independence Ave., S.W.

Washington DC, 20585

Ed Barbour

Navigant Consulting

1801 K Street, NW

Suite 500

Washington DC 20006

Jim McMahon

Lawrence Berkeley National Laboratory

1 Cyclotron Road, 90-4000

Berkeley, CA 94720

Paul Torcellini

National Renewable Energy Laboratory

617 Cole Boulevard, Mail Stop 2722

Golden, CO 80401-3393

\section{ONSITE}

Pacific Northwest National Laboratory

D.M. Anderson K5-06

D.B. Belzer K5-06

K.A. Cort K5-06

J.A. Dirks K6-10

M.A. Halverson Offsite

D.J. Hostick K5-06

R.E. Jarnagin K5-16

S.C. McDonald BWO

A.K. Nicholls BWO

M. Placet BWO

M.J. Scott K5-06

Information Release Office K1-06 